\title{
Pythian Powerhouse and Laundry
}

Historic Building Survey

Sunny Stone, Adam Smith, and Sara Lask

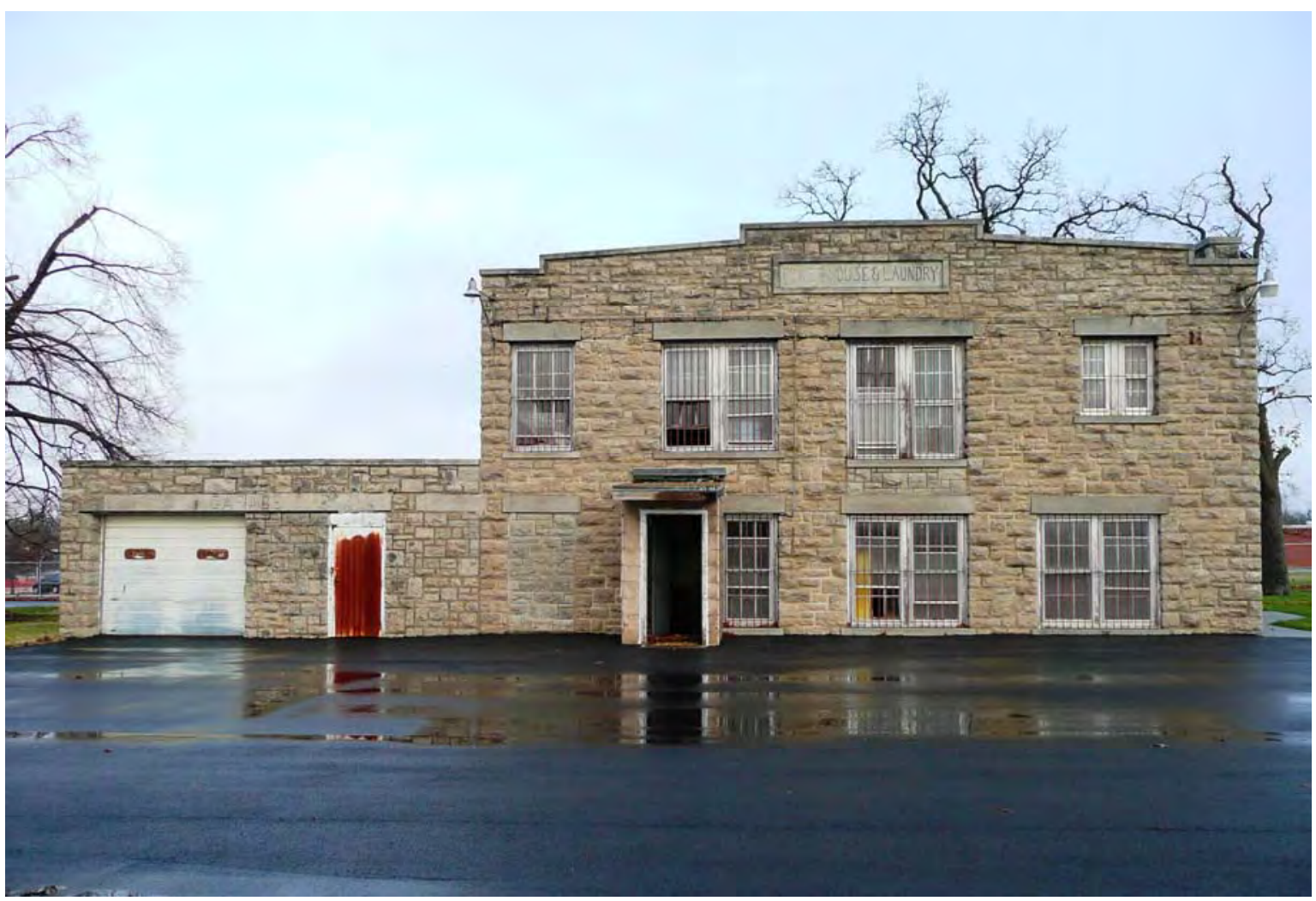




\section{Pythian Powerhouse and Laundry}

Historic Building Survey

Sunny Stone, Adam Smith, and Sara Lask

Construction Engineering Research Laboratory (CERL)

U.S. Army Engineer Research and Development Center

2902 Newmark Dr.

Champaign, IL 61822-1076

Final Report

Approved for public release; distribution is unlimited.

Prepared for U.S. Army Reserve

89th Regional Readiness Command

Wichita, KS 67210 


\begin{abstract}
The Pythian Powerhouse and Laundry building is eligible for the National Register of Historic Places. This report documents the building in a similar style to the Historic American Buildings Survey standard. This report satisfies Section 110 of the National Historic Preservation Act of 1966 as amended and will help the 89th Regional Readiness Command in managing their historic building.
\end{abstract}

DISCLAIMER: The contents of this report arenot to beused for advertising, publication, or promotional purposes. Citation of trade names does not constitute an official endorsement or approval of the use of such commercial products. All product names and trademarks cited are the property of their respective owners. The findings of this report are not to be construed as an official Department of the Army position unless so designated by other authorized documents. 


\section{Table of Contents}

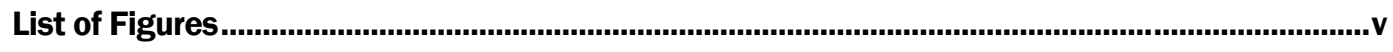

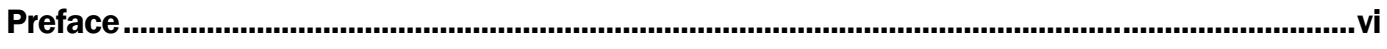

Unit Conversion Factors........................................................................................................................... vii

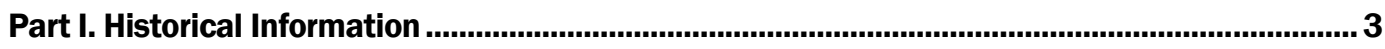

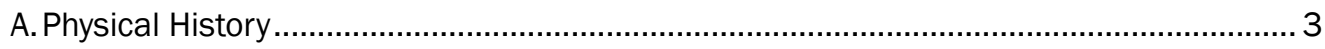

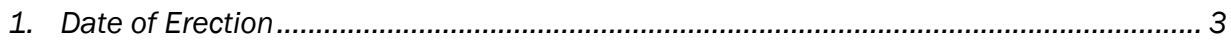

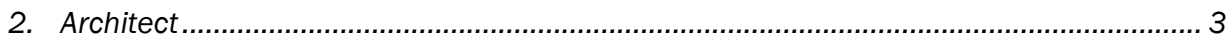

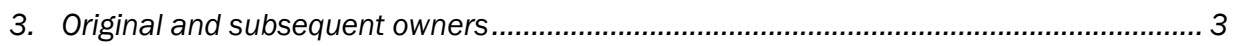

4. Builder, contractor, suppliers.................................................................................. 3

5. Original plans and construction .............................................................................. 3

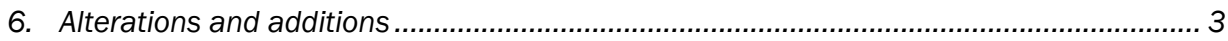

B. Historical Context.................................................................................................. 3

Part II. Architectural Statement.............................................................................................. 8

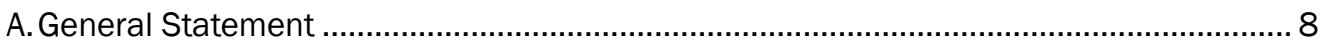

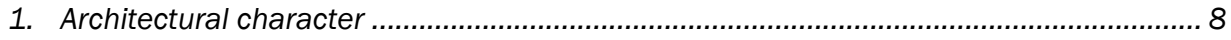

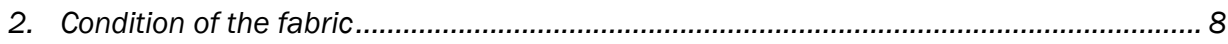

B.Description of Exterior ............................................................................................. 8

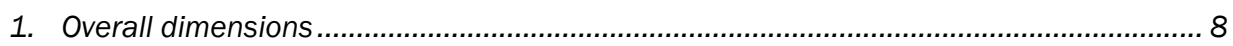

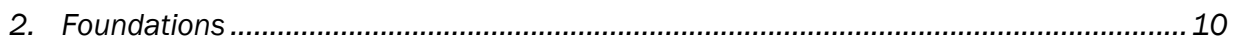

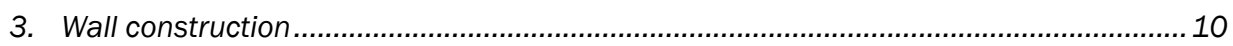

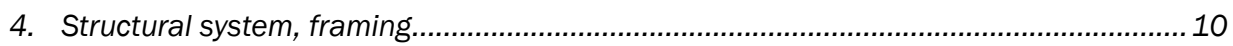

5. Porches, stoops, balconies, bulkheads .................................................................... 10

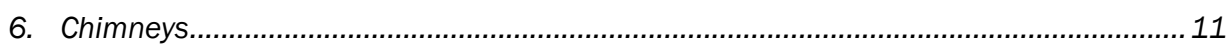

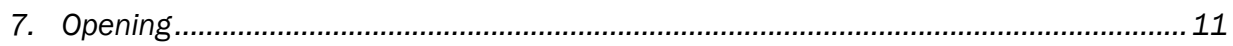

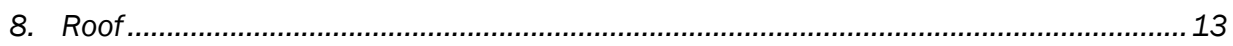

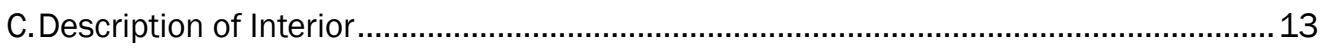

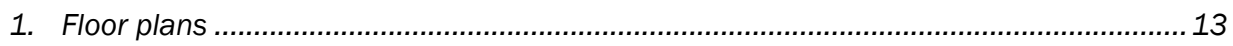

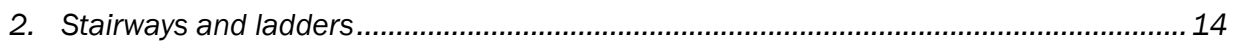

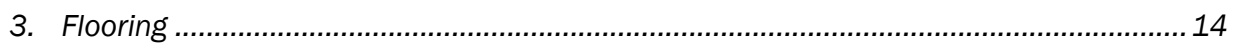

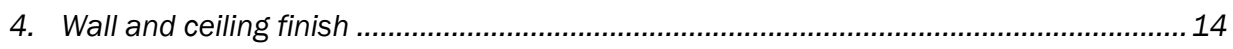

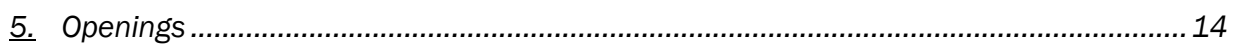

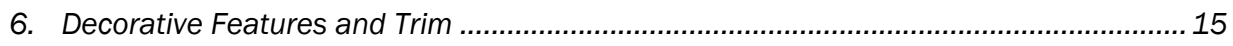

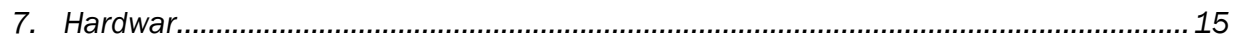

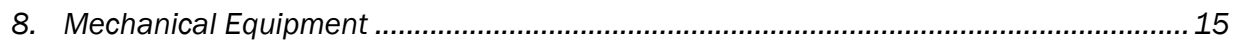

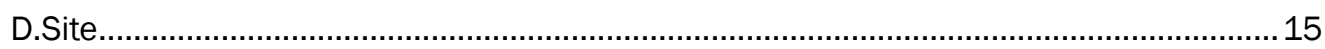

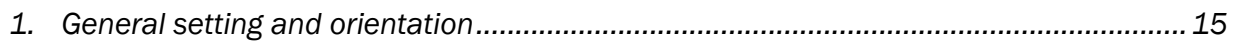

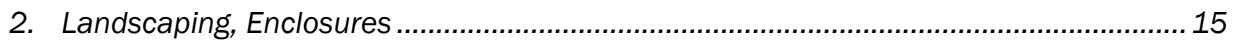




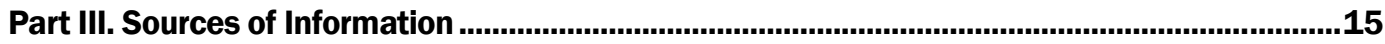

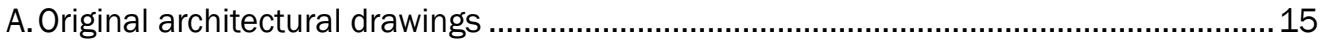

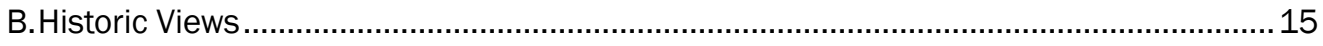

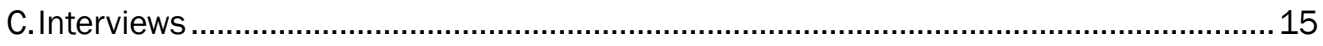

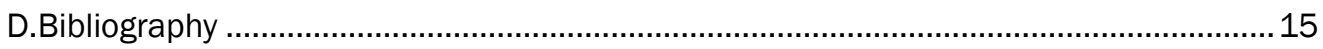

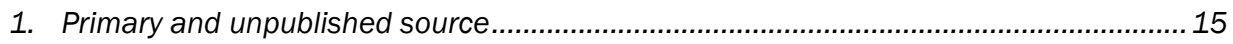

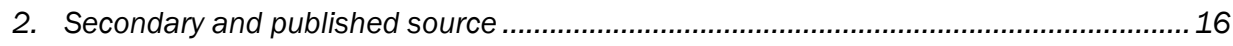

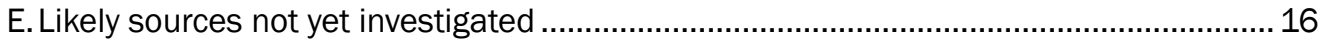

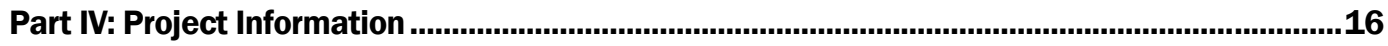

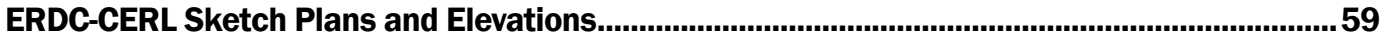

Report Documentation Page ............................................................................................... 


\section{List of Figures}

\section{Figures}

1 Pythian Home soon after opening, no date (courtesy current owners of the

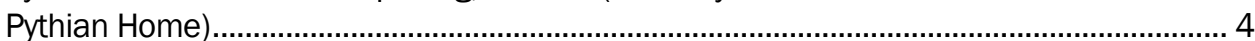

2 Orphans at the Pythian Home, no date (courtesy current owners of the Pythian

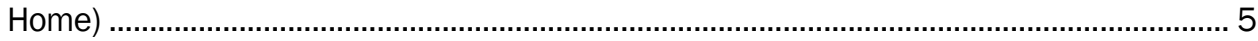

3 Map of O'Reilly General Hospital, 1942 (National Archives at College Park) ...................... 6

4 O’Reilly General Hospital Guardhouse, 1942 (courtesy Springfield-Greene

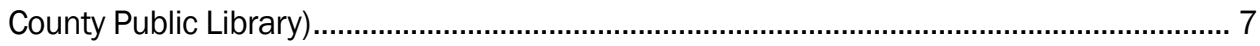

5 U.S Army Reserve, no date (89th RRC) ........................................................................ 7 


\section{Preface}

This study was conducted for the 89th Regional Readiness Command, Wichita, Kansas, under project number 147634, "Architectural Survey for Springfield, MO." Funding was provided by Military Interdepartmental Purchase Request (MIPR) 21/2020/220/ MIPR7CDENVD001/PO, dated 15 August 2007. The 89th RRC technical monitor was Kate Ellison, Environmental Coordinator.

The work was performed by the Land and Heritage Conservation Branch (CN-C) of the Installations Division (CN), Construction Engineering Research Laboratory (CERL). The CERL Project Manager was Adam Smith. Dr. Christopher White is Chief, CN-C, and Dr. J ohn Bandy is Chief, CN. The Deputy Director of CERL is Dr. Kirankumar V. Topudurti. The Director of CERL is Dr. Ilker R. Adiguzel.

CERL is an element of the United States Army Engineer Research and Development Center (ERDC), United States Army Corps of Engineers. The Commander and Executive Director of ERDC is COL Gary E. J ohnson and the Director of ERDC is Dr. J ames R. Houston. 


\section{Unit Conversion Factors}

\begin{tabular}{|l|c|l|}
\hline Multiply & By & To Obtain \\
\hline feet & 0.3048 & meters \\
\hline inches & 0.0254 & meters \\
\hline
\end{tabular}


PYTHIAN POWERHOUSE and laundry

(Building No. 503)

Pythian Home

Division Street on the north, Glenstone Avenue on the east, Pythian Street on the south, and Fremont Avenue on the west

Springfield

Greene County

Missouri

\title{
PHOTOGRAPHS
}

WRITTEN HISTORICAL AND DESCRIPTIVE DATA

\author{
HISTORIC AMERICAN BUILDINGS SURVEY \\ MIDWEST REGIONAL OFFICE \\ National Park Service \\ U.S. Department of the Interior \\ 601 Riverfront Drive \\ Omaha, NE 68102
}




\title{
HISTORIC AMERICAN BUILDINGS SURVEY
}

\section{PYTHIAN POWERHOUSE AND LAUNDRY}

\author{
(Building No. 503)
}

Location: $\quad$ South of Division Street, north of Pythian Street, east of Fremont Avenue, and west of Glenstone Avenue, Springfield, Greene County, Missouri USGS Springfield, Missouri, United States Quadrangle, Universal Transverse Mercator Coordinates: Zone 15.4119384.476230

\section{Present Owner: $\quad$ Headquarters}

United States Army Reserve 89th Regional Readiness Command

3130 George Washington Boulevard

Wichita, Kansas 67210-1598

Original Use: Powerhouse and Laundry

Present Use: Vacant

Significance: The former Pythian Home, located at 1451 Pythian Street, is a large and imposing castle-like structure constructed of cut limestone blocks. It was built in 1915 by the Grand Lodge of Knights of Pythias, a purely fraternal order, as a home for aged members and orphaned children of members of the lodge. The property was sold to the United States Government in 1942 during World War II as only a few people were residing there. The Pythian Home became part of the U.S. Army O’Reilly General Hospital. The home was used as the Enlisted Mens' Service Club. The service club was the location of various recreational activities and remained as such until the hospital was deactivated in 1946. The Pythian Home was used by the Army Reserve from 1946 to 1993 until it was sold into private ownership.

Along with the construction of the large Pythian Home, a small-scale version of the castle-like structure was also constructed in 1915 as the support building for the Pythian Home. The Pythian Powerhouse and Laundry was built on the north side of the Pythian Home. The structure housed the boiler and laundry facility for the Pythian Home. Like the Pythian Home, the Powerhouse and Laundry building was incorporated into the O'Reilly General Hospital plan and was utilized as a guard house. The Powerhouse and Laundry building was retained by the Army Reserve after the main building was sold at government auction. It remains in their ownership today. 


\section{PART I. HISTORICAL INFORMATION}

A. Physical History

1. Date of Erection: 1915.

2. Architect: Unknown.

3. Original and Subsequent Owners: Grand Lodge of Knights of Pythias, United States Government (part of the O’Reilly General Hospital), United States Army Reserve, private ownership, United States Army Reserve.

4. Builder, Contractor, Suppliers: Grand Lodge of Knights of Pythias.

5. Original Plans and Construction: Unknown.

6. Alterations and Additions: Some of the windows have been replaced, two original windows have been removed and the openings have been filled in with stone on the south elevation (Photo 1), one set of paired windows has been removed and the opening has been filled in with stone on the north elevation (Photo 11), one window of a paired set of windows has been removed and the opening filled with a door on the north elevation (Photo 11), the original brick chimney stack has been removed (Photo 9), the entry doors have been replaced, the overhead garage door has been replaced, and a small vestibule has been constructed on the south elevation (Photos 5-6). The interior of the building had a large boiler room that encompassed the current basement and first floor. At some point, a wood floor was added to divide the boiler room into two separate floors (Plan 11).

It is unknown if the one-story garage on the west side of the two-story Powerhouse and Laundry building was original to the design or if it was added at a later date. Also there is a window modification on the south elevation second floor. It is believed that the paired windows in the middle of the second floor replace a door opening (Photo 21). This door opening would have been added during World War II to provide access to the laundry area on the second floor. The windows that currently fill in the door opening are slightly larger than the other paired wood double-hung windows found on the building and the limestone located below the opening is slightly different in texture and in color.

\section{B. Historical Context}

The Powerhouse and Laundry building was originally constructed in 1915 as a support building for the large Pythian Home (see Figures 1-2). The Powerhouse and Laundry building was originally constructed of cut limestone and mimics the castle-like architectural design of the Pythian Home. The Powerhouse and Laundry was sold by the Knights of Pythias to the War Department in 1942. At this time, the building became part of the O’Reilly General Hospital (see Figure 3). 
Since the original hospital plan already included a powerhouse, the Pythian Powerhouse and Laundry building was used as a guardhouse (see Figure 4). The original towering chimney was more than likely removed at this time. The original boiler room was modified with the addition of a wood floor that divided the space into two floors. The boiler was also removed at this time. It is unknown, but the windows placed on the first floor at ground level were more than likely added or the original window openings were enlarged. A utility tunnel connects the basement of the Pythian Home to the former boiler room of the Powerhouse and Laundry building. This tunnel housed the pipes carrying steam from the boiler to the radiators in the Pythian Home. The Pythian Home was used by the Army Reserve from 1946 to 1993 (see Figure 5) until it was sold into private ownership.

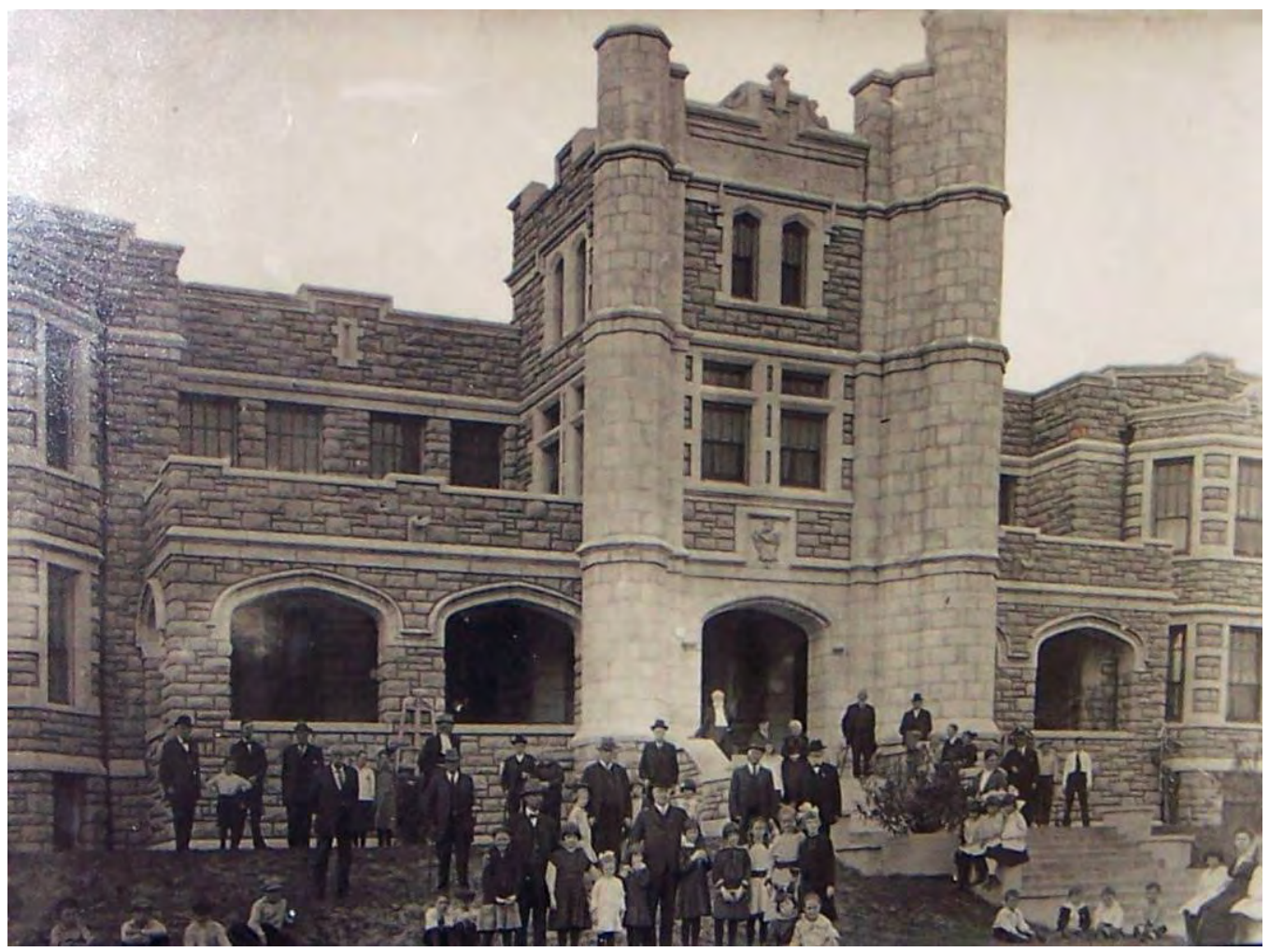

Figure 1. Pythian Home soon after opening, no date (courtesy current owners of the Pythian Home). 


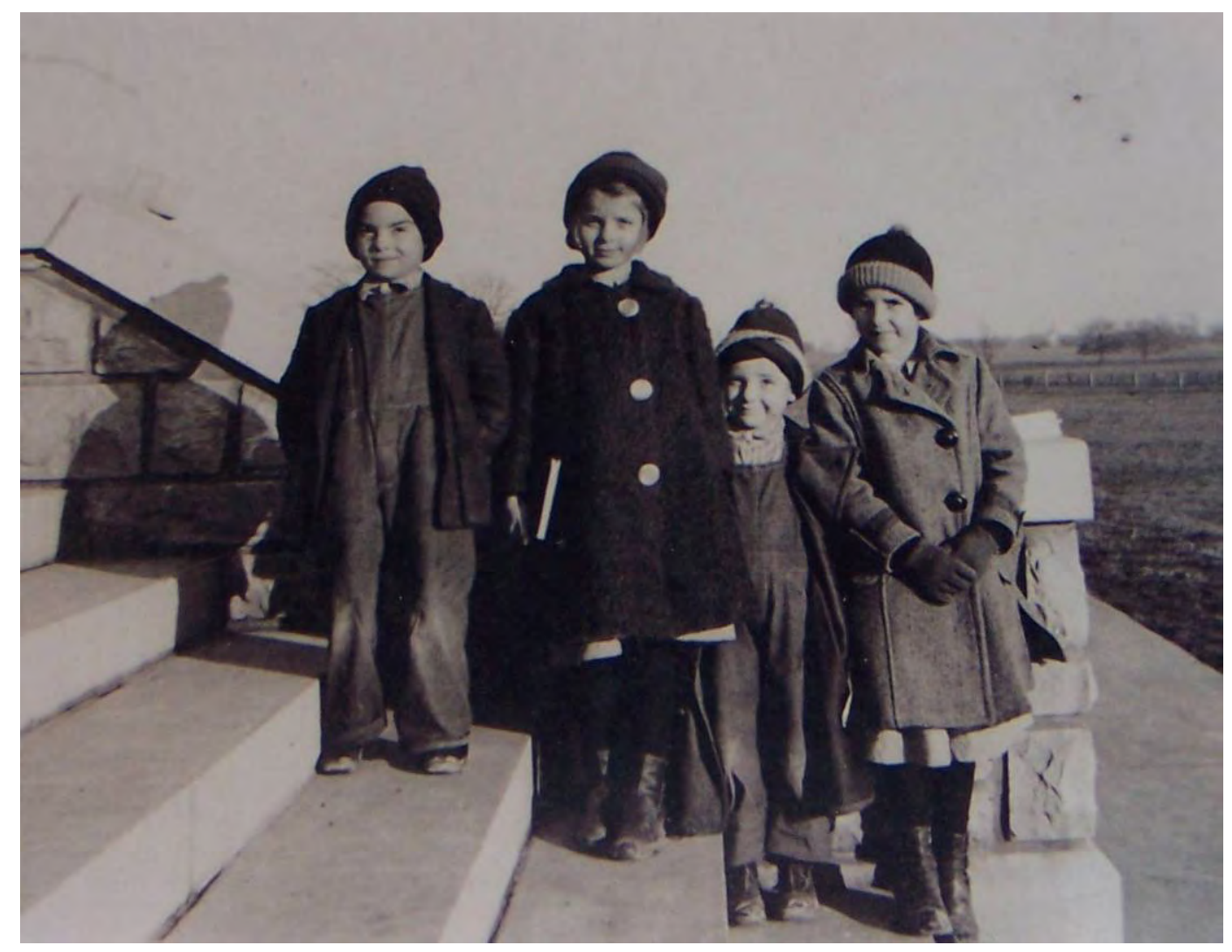

Figure 2. Orphans at the Pythian Home, no date (courtesy current owners of the Pythian Home). 
PYTHIAN POWERHOUSE AND LAUNDRY

(page 6)

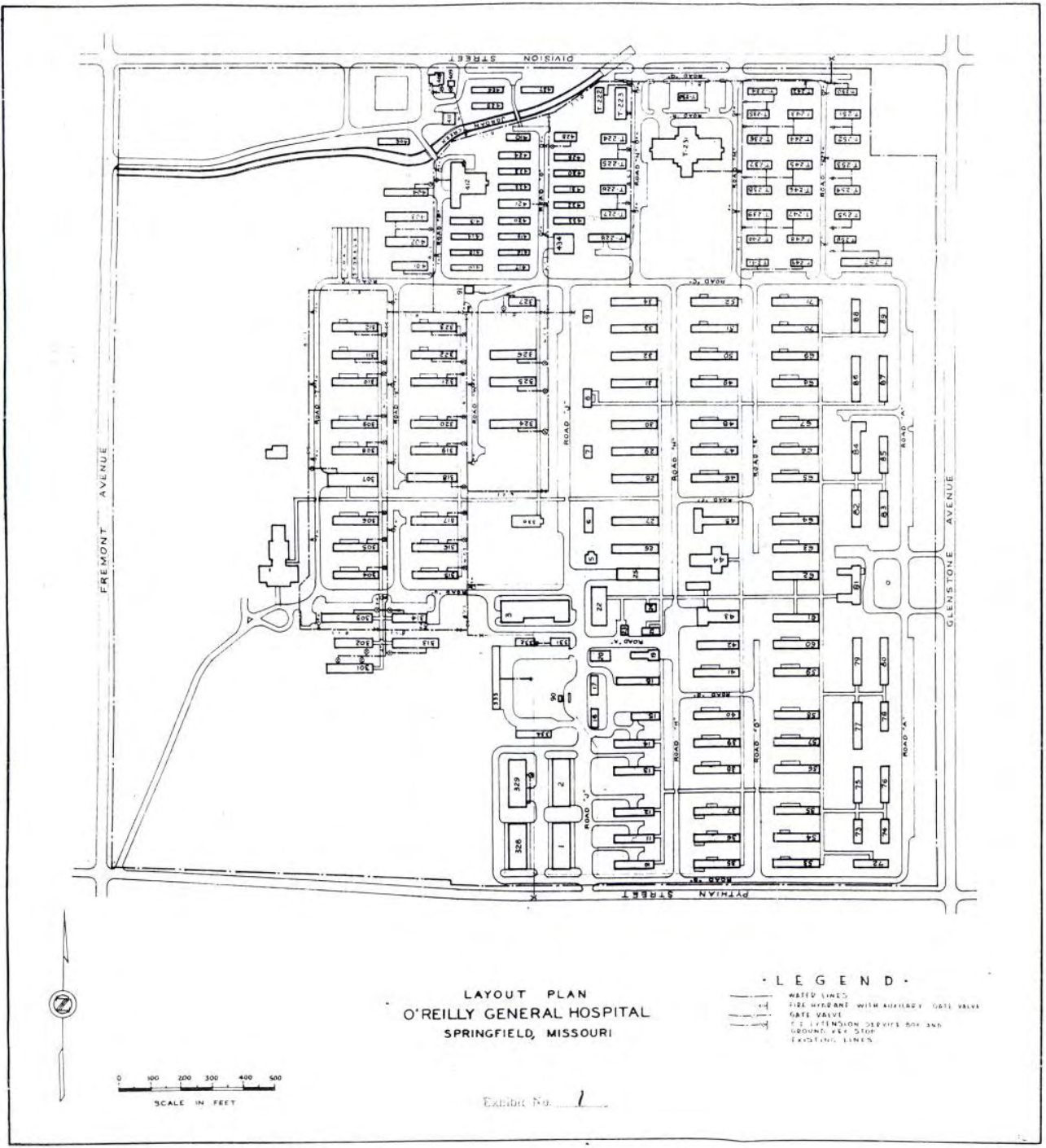

Figure 3. Map of O’Reilly General Hospital, 1942 (National Archives at College Park). 


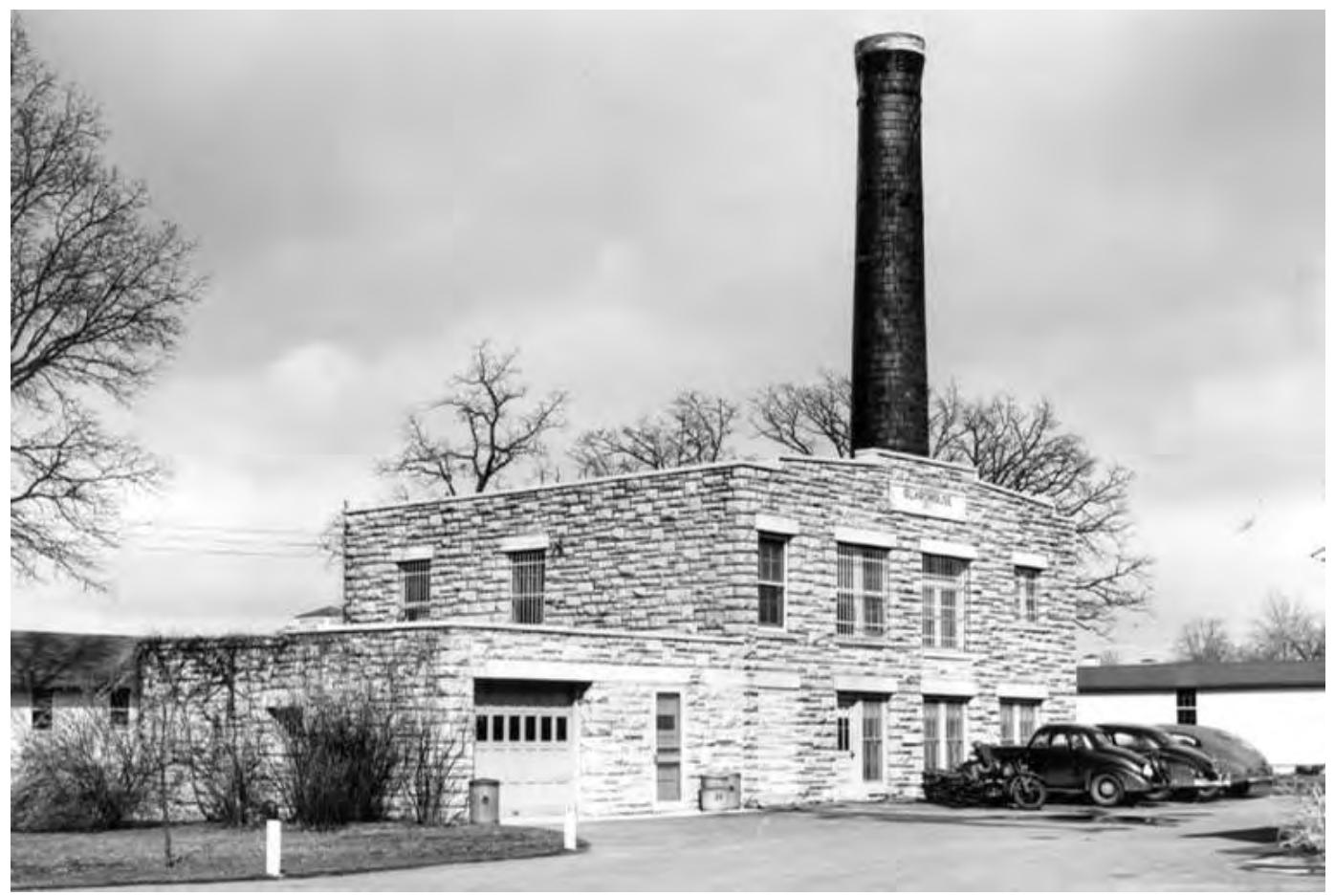

Figure 4. O’Reilly General Hospital Guardhouse, 1942 (courtesy SpringfieldGreene County Public Library).

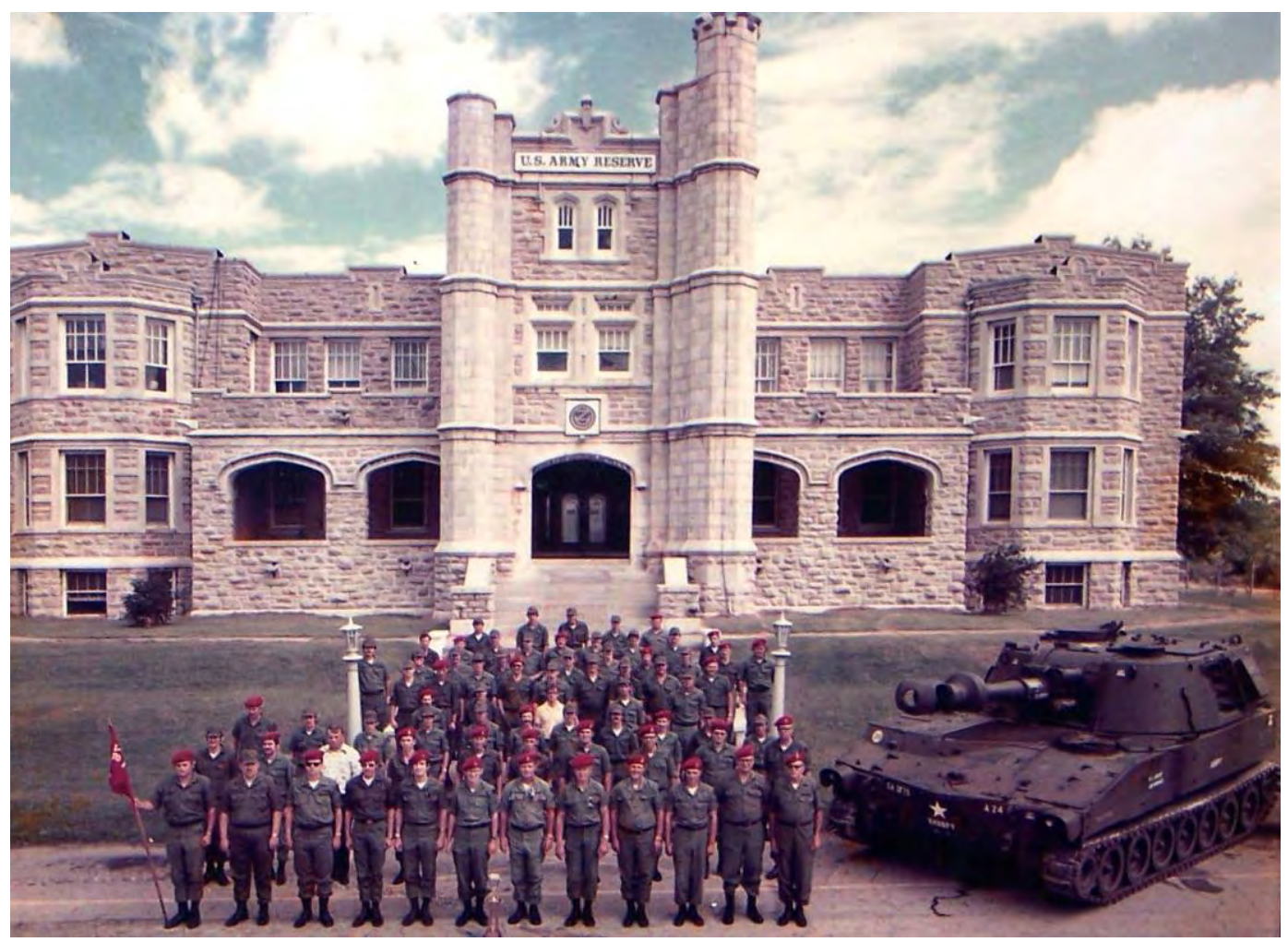

Figure 5. U.S Army Reserve, no date (89th RRC). 


\section{PART II. ARCHITECTURAL STATEMENT}

\section{A. General Statement}

1. $\quad$ Architectural Character: The Pythian Powerhouse and Laundry building looks like an artistic block of stone (Photo 1). The building is a rectangular structure that rises straight from the ground with no detail or watertable. The structure has two distinct areas defined by two different roof heights. Both spaces are covered with sloped roofs. The slope of the roofs decrease from the south (front) to the north (back) of the building. The two-story roof has a stepped parapet wall. The main elevation is on the south and is defined by a one-story garage space and several paired wood double-hung windows. The remnants from the original towering cut limestone and terra cotta tile chimney stack are located on the east elevation. There are two engraved concrete names on the south elevation. One reads "GARAGE" above the garage door opening and the other reads "POWER HOUSE \& LAUNDRY" above the second floor windows. Concrete lintels are located above the window openings. Two original decorative light fixtures are on the south elevation.

The original boiler room was divided by a wood floor that was added during World War II. The basement floor is left open with several wood columns and two concrete columns. The first floor addition is left open, with few dividing walls. Several temporary metal cage storage units occupy the second floor. Two concrete columns run continuous from the basement floor to the two concrete beams that support the second floor roof. A bathroom is located on the second floor. More than likely, this bathroom dates to the original construction of the building. All of the fixtures including the toilet, urinal, mop sink, and sink date to that period. The radiators on the first floor seem to be added during World War II, while the second floor has original radiators. A wood staircase provides access from the ground floor to the second floor.

2. Condition of the fabric: The foundation and overall structure of the Powerhouse and Laundry building are in good condition. The sturdiness of the building is attributed to the types of materials--concrete foundation and floors and cut limestone walls; however, one potential problem could arise in the future. The design of the window placement on the first floor (ground level) has the bottom of the windows located near the ground. Since there is no watertable to shed rainwater from the building nor window sills to keep water out of the windows at the ground level, all of these windows are subject to rot, water damage, and insect damage.

\section{B. Description of Exterior}

1. $\quad$ Overall Dimensions: The Pythian Powerhouse and Laundry building is a rectangular mass with two different sloped roofs, a garage space on the 
west side of the building, and the main entrance on the south elevation. The overall dimension of the building is approximately $60^{\prime}-11^{\prime \prime} \times 28^{\prime}-1^{\prime \prime}$. The one-story garage roof is $10^{\prime}-10^{\prime \prime}$ high on the south (front) elevation and slopes to $9^{\prime}-51 / 2^{\prime \prime}$ high on the north (back) elevation. The two-story roof height is $21^{\prime}-4^{\prime \prime}$ above grade. The cut limestone walls are $1^{\prime}-10^{\prime \prime}$ thick.

The south elevation (Photo 1) is the main elevation of the building that faces an open, paved parking lot and the rear of the Pythian Home. The south elevation is two different heights. The left side of the elevation is one-story and houses what use to be the garage space (Photo 2). This portion is covered with a sloped roof and a straight parapet with concrete capping. A metal replacement overhead garage door provides access into the one-story interior space. A replacement single metal entry door is located to the right of the garage door opening. This door is showing signs of severe rust damage. A concrete lintel stretches across the garage door opening and is located above the replacement metal door and the letters "GARAGE" are etched into the concrete (Photo 3). To the right of the door on the one-story portion of the exterior wall, an original window has been removed and the opening has been filled in with stone. The concrete lintel remains above the filled opening (Photo 4). The right side of the south elevation is two stories in height and is dominated by several paired wood double-hung windows. This portion of the building is covered with a sloped roof defined by a stepped parapet with concrete capping. There is one single window opening that has been filled in with stone. This window is located on the first floor and to the right of the other filled opening described above. The concrete lintel is intact. To the right of this filled window is a vestibule addition (Photo 5). A small wood structure has been constructed in front of the original single entry door. The vestibule is clad with asbestos cement siding and has a shed roof covered with asphalt shingles. Adjacent to the vestibule is a single six-over-six wood doublehung window (Photo 6). Two sets of paired six-over-six wood doublehung windows are located on the right side of the first floor. The second floor of the exterior wall contains a single six-over-six wood double-hung window, two sets of paired six-over-six wood double-hung windows, and a set of smaller paired four-over-four wood double-hung windows. Located above the windows in the center of the wall is a concrete sign. Etched in the sign are the letters "POWER HOUSE \& LAUNDRY" (Photo 7). Two decorative light fixtures are located at the top edges of the exterior wall (Photo 8).

The east elevation (Photo 9) is where the original chimney stack was located. A majority of the stack is intact; however, the top portion of the stack that extended above the two-story roof height has been removed and has been capped off (Photo 10). The chimney is located in the center of the elevation and is five-sided. There are two sets of paired wood doublehung windows on the first floor; one on each side of the chimney. One single six-over-six wood double-hung window is to the right of the chim- 
ney on the second floor. All three windows have a concrete lintel above and are covered with metal security bars.

The north elevation (Photo 11) is defined by several window openings. The majority of the elevation is two-stories tall. The first floor of the twostory exterior wall has a window opening modified with one window and a replacement door (Photo 12), one set of paired six-over-six wood doublehung windows, a modified window opening that has been filled in with stone, and one single six-over-six wood double-hung window. The second floor consists of four evenly spaced single six-over-six wood double-hung windows. All of the windows have concrete windowsills and lintels and are covered with metal security bars. The right side of the north elevation is recessed from the two-story portion. The right side is one-story tall and has one smaller three-pane wood awning window with a concrete windowsill and a small single-pane fixed window without a concrete windowsill (Photo 27).

The west elevation (Photo 13) is divided into two parts. The one-story garage space occupies the foreground, while the two-story space is in the background. The one-story exterior wall of the garage has one small threepane wood window with a concrete windowsill and lintel and is covered with metal security bars. The second floor of the two-story exterior wall has two single six-over-six wood double-hung windows. Each window has a concrete windowsill and lintel and is covered with metal security bars.

2. Foundations: The foundation consists of a concrete floor with cut limestone walls.

3. Wall Construction: The walls of the building are $1^{\prime}-10^{\prime \prime}$ thick. The exterior walls are composed of cut limestone. The stone is exposed on both the exterior and interior. The majority of the interior is left open with the exception of a small enclosed bathroom in the northwest corner of the second floor. Wood stud walls enclose this space.

4. Structural System, Framing: The building has a simple structural system. The exterior walls are approximately 1 '-10" thick cut limestone. Two concrete columns are located in the two-story space that extends from the lower level (basement) up through the second floor. These 1'-0" by 1'-0" columns are set within a concrete pier. Each column base measures $1^{\prime}-6^{\prime \prime}$ by $1^{\prime}-6^{\prime \prime}$. The columns are located $24^{\prime}-0^{\prime \prime}$ from the east wall and $12^{\prime}-2^{\prime \prime}$ and $24^{\prime}-10^{\prime \prime}$ from the south wall (Photo 14 ). Newer $0^{\prime}-8$ " by 0 '-8" wood columns are spread throughout the basement to support the wood floor addition above. These columns are set within concrete foundations (Photo 15).

5. $\quad$ Porches, Stoops, Balconies, Bulkheads: There are none. 
6. Chimneys: A five-sided chimney is located on the exterior of the east wall (Photo 16). The chimney is constructed of the same cut limestone. The original stack has been removed and the remaining portion of the chimney has been capped. The chimney width is $10^{\prime}-0^{\prime \prime}$ across. The five sides measure $4^{\prime}-6^{\prime \prime}, 3^{\prime}-8^{\prime \prime}, 3^{\prime}-10^{\prime \prime}, 3^{\prime}-8^{\prime \prime}$, and $4^{\prime}-6^{\prime \prime}$. The current height of the chimney is $22^{\prime}-0^{\prime \prime}$.

\section{7. $\quad$ Opening}

a. Openings: There are none.

b. Doorways and doors: There are four door openings on the building. The main entrance is located on the south elevation. A wood frame vestibule addition clad with asbestos cement siding has been constructed in front of the door opening. The door opening for the vestibule measures $2^{\prime}-7^{\prime \prime}$ by $7^{\prime}-0^{\prime \prime}$. The main front entry door measures $3^{\prime}-1$ " by $7^{\prime}-0$ ". There are also two more doors on the south elevation. One is a replacement metal garage door (Photo 17). The door is placed $2^{\prime}-10^{\prime \prime}$ from the edge of the building. The door opening is $10^{\prime}-1$ " wide by $7^{\prime}-8$ " tall. The other door is located $5^{\prime}-3^{\prime \prime}$ to the right of the garage door opening. This replacement metal door measures $3^{\prime}-0^{\prime \prime}$ by $6^{\prime}-71 / 2$ ". The fourth door is located on the north elevation. This door was not original to the design. A set of paired windows has been modified. One of the wood windows has been removed and the opening has been filled with a plywood door. The door is located $1^{\prime}-8^{\prime \prime}$ from the left side of the north elevation. It is approximately $2^{\prime}-10^{\prime \prime}$ by $6^{\prime}-71 / 2 "$.

c. Windows and_shutters: Several wood windows are on the building. It is unknown if these windows are original to the 1915 construction or if they were replaced in 1942 when the War Department took over the building. There are eight types of wood windows on the building. Each window has a $1^{\prime}-0^{\prime \prime}$ concrete lintel and $0^{\prime}-3 \frac{1}{2} 2^{\prime \prime}$ concrete windowsill. All but one small three-pane wood window are covered with metal security bars. The majority of the windows are set $0^{\prime}-6^{\prime \prime}$ into the cut limestone walls.

Type 1: A single six-over-six wood double-hung window that measures 3'-7" by 6'-3" with 0'-51/2" frame (Photo 18).

Type 2: Paired six-over-six wood double-hung windows that measure 2'-9" by 6'-11/2" each; divided by 0 '-51/2" frame with a total width of (including framing members) 6'-81/2" (Photo 19).

Type 3: Larger paired six-over-six wood double-hung windows that measure 6'-41/2" by 6'-51/2" (Photo 20). 
Type 4: Smaller paired six-over-six wood double-hung windows that measure $1^{\prime}-8{ }^{1 / 2}$ " by $4^{\prime}-1^{\prime \prime}$ each; divided by $0{ }^{\prime}-81 / 2$ " frame with a total width of (including framing members) 4'-11" (Photo 21).

Type 5: Small wood three-pane awning window that measures 3'8" by 2'-4" (Photo 22).

Type 6: Small single-pane wood fixed window that measures 1'-8" by $1^{\prime}-0 "$ and is framed with $2 x 4$ members (Photo 23).

Type 7: Originally a single window with window removed and opening filled with cut limestone (Photo 24).

Type 8: Original paired windows with the windows removed and the opening filled with cut limestone. The concrete windowsill has been removed (Photo 25).

The south elevation has five window types. Three Type 2 windows are on the ground level; however, one of the window openings has been modified. One of the paired windows has been removed and the opening has been filled with a door (the vestibule addition is located in front of this window). To the left of the vestibule addition are two Type 6 windows. The second floor consists of Type 1, Type 3, and Type 4 windows. Type 1 and Type 2 are positioned $10^{\prime}-1$ " above ground level. Type 3 is positioned $9^{\prime}-6$ " above ground level. Type 4 is positioned $12^{\prime}-1 \frac{1}{2} 2^{\prime \prime}$ above ground level.

The east elevation consists of two Type 2 windows at ground level and one Type 1 window that is $10^{\prime}-4 \frac{1}{2} 2^{\prime \prime}$ above ground level.

The majority of the north elevation is two stories with the right side one-story portion recessed $10^{\prime}-7^{\prime \prime}$ from the left. Several windows are on the two-story exterior wall. The ground level consists of three Type 2 windows; however, the window on the far left has been modified. One of the paired windows has been removed and the opening is currently filled with a door. There is also a Type 7 window on the ground level that is located 25'-9 1/4" from the left edge of the north elevation. Four Type 1 windows are evenly spaced across the second floor. These windows are approximately $2^{\prime}-5$ " above the lintel of the ground floor windows. The one-story exterior wall has one Type 5 window positioned $3^{\prime}-1 \frac{1}{1} 2^{\prime \prime}$ from the left edge of the one-story wall that is $3^{\prime}-01 / 2$ " above the ground and one Type 6 window located $13^{\prime}-2^{\prime \prime}$ to the right of the Type 5 window.

The west elevation is divided into two parts. The one-story garage space occupies the foreground, while the two-story space is in the background. There is one Type 5 window on the one-story exterior 
wall located approximately $12^{\prime}-10^{\prime \prime}$ from the left edge and $3^{\prime}-8$ " above ground level. Two Type 1 windows are located on the twostory exterior wall.

\section{8. $\quad \underline{\text { Roof }}$}

a. Shape, covering: There are two sloped roofs that cover the interior of the building. One roof is located over the one-story garage space and the other is located over the two-story Powerhouse and Laundry building space. Both roofs slope from the south (front) to the north (back) of the building. The roofs are constructed of concrete. The one-story roof has a parapet wall on the west edge of the roof. This parapet wall slopes downward from the middle (Photo 27). The two-story roof also has a parapet wall on the south, east, and west edges of the roof. The south parapet wall is designed as a step parapet (Photo 28). Both roofs have concrete capping.

b. Cornice, eaves: None.

c. Dormers, cupolas, towers: None.

\section{Description of Interior}

1. Floor Plans: The floor plan of the building is rectangular. The west portion of the plan is one-story and was used as garage space. The majority of the plan was originally used as the powerhouse and had a large open space that once contained the boiler. Currently, this space has been divided into two floors with the addition of a wood floor. A set of wood stairs is located near the adjoining wall to the garage space. These stairs lead down to the current basement. A set of switchback concrete stairs leads from the entry door level up to the second floor. The walls that surround these stairs are constructed of concrete on the first floor, while a metal security cage surrounds the stair opening on the second floor.

a. Basement: The basement is $7^{\prime}-0^{\prime \prime}$ below grade level. The space is left open (Photo 29). Only concrete and wood columns dot the plan. A poured concrete ramp leads up from the basement to the ground level; however, the wood floor addition makes the ramp non-functional. The ramp is located along the east wall. More than likely, this ramp was used to bring coal into the basement for the boiler. The boiler and chimney base are located on the east wall. The original boiler opening has been filled in with concrete masonry units. The tunnel that connects the powerhouse to the Pythian Home is located on the south wall and is accessed at the lower level. Currently, this opening has been blocked over.

b. $\quad$ First floor: The first floor was added to the building at some point (more than likely during World War II when the building was 
transformed from a powerhouse into a guardhouse). The wood floor is 1'-6" below grade. The first floor is open except metal cage security walls were installed at some point by the Army Reserve.

c. Second floor: The majority of the second floor is open with the exception of a small enclosed bathroom located in the northwest corner. The bathroom measures $11^{\prime}-2^{\prime \prime}$ by $8^{\prime}-11^{\prime \prime}$. Inside the bathroom are a toilet, urinal, sink, mop sink, and shower stall (Photos 30, 31, 32, and 33). This bathroom is more than likely original to the building and utilized when this floor was a laundry. All of the fixtures date to this period. Two concrete columns are located near the center of the plan. The remainder of the second floor is subdivided into smaller spaces by metal cage security walls were installed at some point by the Army Reserve (Photo 34).

2. Stairways and Ladders: There are two sets of stairs. One is constructed of wood and leads to the lower level (Photo 35). This stair is located just off of the entry on the south wall. There is another stair adjacent to the wood stair. This stair is constructed of concrete and leads to the second floor. The concrete stairs switchback with a 3'-7" wide with, $0^{\prime}-9$ " risers, and $0^{\prime}$ $10^{\prime \prime}$ treads. The concrete landing measures 3'-3" by 7'-10" (Photos 36 and 37).

3. Flooring: The floors in the one-story garage space, basement, and second floor are poured concrete. The flooring on the first floor is wood.

4. Wall and Ceiling Finish: The inside of the exterior walls are left as exposed cut limestone; however, several coats of paint or sealant have been added (Photo 38). The bathroom walls are wood stud with drywall.

The ceiling finish in the garage is unknown but more than likely is left as exposed concrete. The ceiling of the second floor is concrete (Photo 39). The ceiling of the basement is the under side of the wood first floor.

\section{5. $\quad$ Openings}

a. Openings: There are none.

b. Doorways and doors: There are few interior doorways and only one door on the interior. One wood five-panel door leads from the entry on the south wall to the concrete stairs up to the second floor. Near this door was a door opening leading from the two-story space to the garage space; however, this opening has been filled with concrete masonry units (Photo 40). The only other doorway is on the second floor leading into the bathroom space. The door is missing but the opening measures $2^{\prime}-61 / 2 "$.

c. Windows: There are none. 
6. Decorative features and trim: There are none.

7. Hardware: There is no original hardware.

8. Mechanical equipment

a. Heating, air conditioning, ventilation: Several radiators are located on the first and second floors. These radiators are placed under the windows (Photos 41, 42, and 43). More than likely, the radiators on the first floor were added by the War Department during World War II and are much less decorative than the original radiators on the second floor.

b. Lighting: The second floor has several older styles of light fixtures that range from bulb to fluorescent.

c. Plumbing: Plumbing was not accessible.

d. Fixtures: There is a toilet, urinal, sink, mop sink, and shower stall located in the bathroom on the second floor. These fixtures date to the original construction of the building in 1915.

9. Original furnishings: There are none.

D. $\quad \underline{\text { Site }}$

1. General setting and orientation: The building is north of Pythian Street, east of Fremont Avenue, south of Division Street, and west of Glenstone Avenue. It is sited to the north of the large castle-like Pythian Home and east of the 89th Regional Readiness Command training center while west of Evangel University.

The building faces south.

2. Landscaping, enclosures: The building faces an asphalt parking lot on the south and is surrounded by grass on the other three sides.

\section{PART III. SOURCES OF INFORMATION}

A. Original architectural drawings: There are none.

B. Historic Views: 89th Regional Readiness Command, Springfield-Greene County Public Library, and the current owners of the Pythian Home.

C. Interviews: None

D. Bibliography

1. $\quad$ Primary and unpublished source: There are none. 
2. Secondary and published source: There are none.

E. Likely sources not yet investigated: None.

\section{PART IV: PROJECT INFORMATION}

Headquarters 89th Regional Readiness Command (RRC), Wichita, Kansas sponsored this project. The project was completed at the Land and Heritage Conservation Branch of the Construction Engineering Research Laboratory (CERL), part of the United States Army Corps of Engineers, Engineer Research and Development Center (ERDC). The project historian was Sunny Stone (CERL). Sunny Stone, with assistance from Adam Smith (CERL), produced the architectural description section of the report and Sara Lask (CERL), produced the architectural sketch drawings section of the report. Photographs contained in this report were taken by Adam Smith and Sunny Stone in December 2006 and December 2007. Documentation was coordinated with the 89th RRC Cultural Resources Program through preservation planner Kate Ellison. The documentation was completed August 2008. 
HISTORIC AMERICAN BUILDING SURVEY

INDEX TO PHOTOGRAPHS

PYTHIAN POWERHOUSE AND LAUNDRY

(Building No.503)

Pythian Home

Division Street on the north, Glenstone Avenue on the east, Pythian Street on the south, and Fremont Avenue on the west

Springfield

Greene County

Missouri

Adam Smith and Sunny Stone, Photographers

DECEMBER 2006, DECEMBER 2007

PHOTO 1 SOUTH ELEVATION; OVERALL VIEW

PHOTO 2 SOUTH ELEVATION OF ONE-STORY GARAGE

PHOTO 3 DETAIL OF “GARAGE” ETCHING

PHOTO 4 VIEW OF MODIFIED FILLED WINDOW OPENING ON SOUTH ELEVATION

PHOTO 5 CLOSE-UP OF VESTIBULE ADDITION ON SOUTH ELEVATION

PHOTO 6 CLOSE-UP OF WINDOW MODIFICATION NEAR VESTIBULE ADDITION ON SOUTH ELEVATION

PHOTO 7 DETAIL OF “POWER HOUSE \& LAUNDRY” ETCHING

PHOTO 8 DETAIL OF ORIGINAL EXTERIOR LIGHT FIXTURE ON SOUTH ELEVATION

PHOTO 9 EAST ELEVATION; OVERALL VIEW

PHOTO 10 CLOSE-UP OF CHIMNEY STACK MODIFICATION

PHOTO 11 LEFT SIDE OF NORTH ELEVATION; OVERALL VIEW

PHOTO 12 CLOSE-UP OF WINDOW MODIFICATION ON NORTH ELEVATION

PHOTO 13 WEST ELEVATION; OVERALL VIEW

PHOTO 14 INTERIOR VIEW OF TWO CONTINUOUS CONCRETE COLUMNS ON SECOND FLOOR 


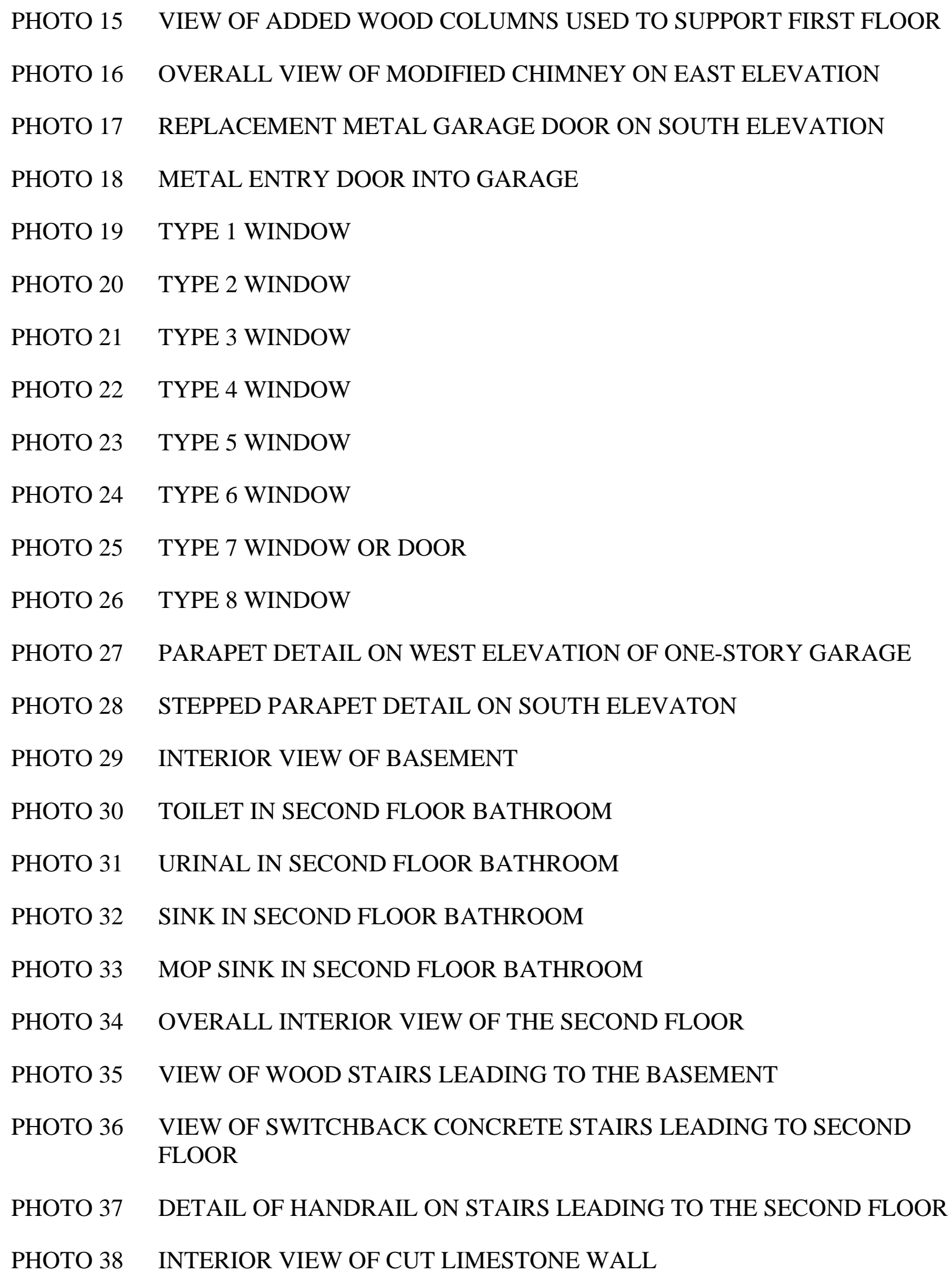


PYTHIAN POWERHOUSE AND LAUNDRY

PHOTOGRAPHS (page 19)

\author{
PHOTO 39 VIEW OF CONCRETE CEILING \\ PHOTO 40 VIEW OF FIVE-PANEL WOOD INTERIOR DOOR AND DOOR OPENING \\ FILLED WITH CONCRETE MASONRY UNITS \\ PHOTO 41 EXAMPLE OF RADIATOR ON SECOND FLOOR \\ PHOTO 42 EXAMPLE OF RADIATOR ON FIRST FLOOR \\ PHOTO 43 EXAMPLE OF ORIGINAL RADIATOR ON SECOND FLOOR
}


PYTHIAN POWERHOUSE AND LAUNDRY

PHOTOGRAPHS (page 20)

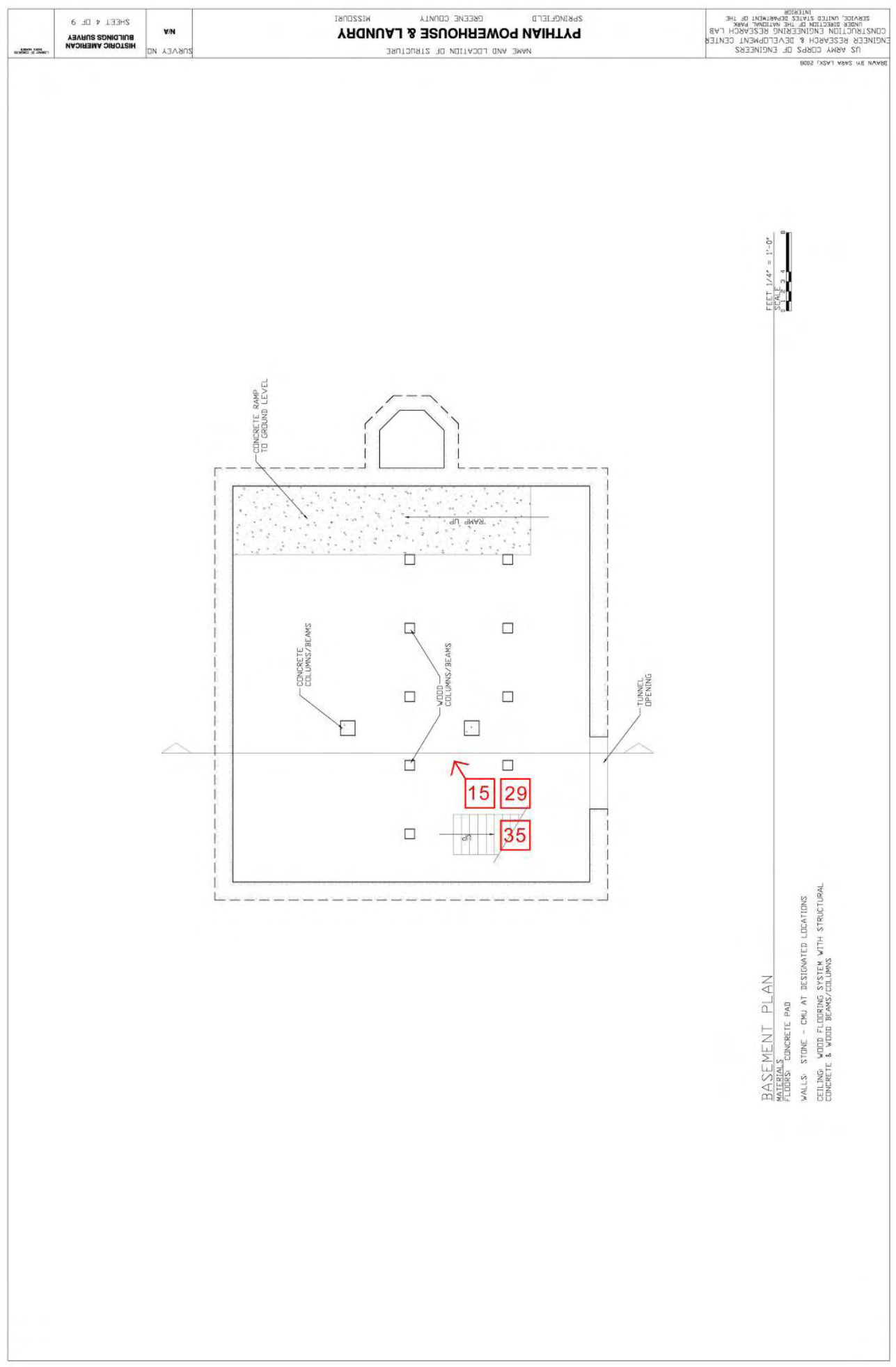

Basement Photograph Locations 
PYTHIAN POWERHOUSE AND LAUNDRY PHOTOGRAPHS (page 21)

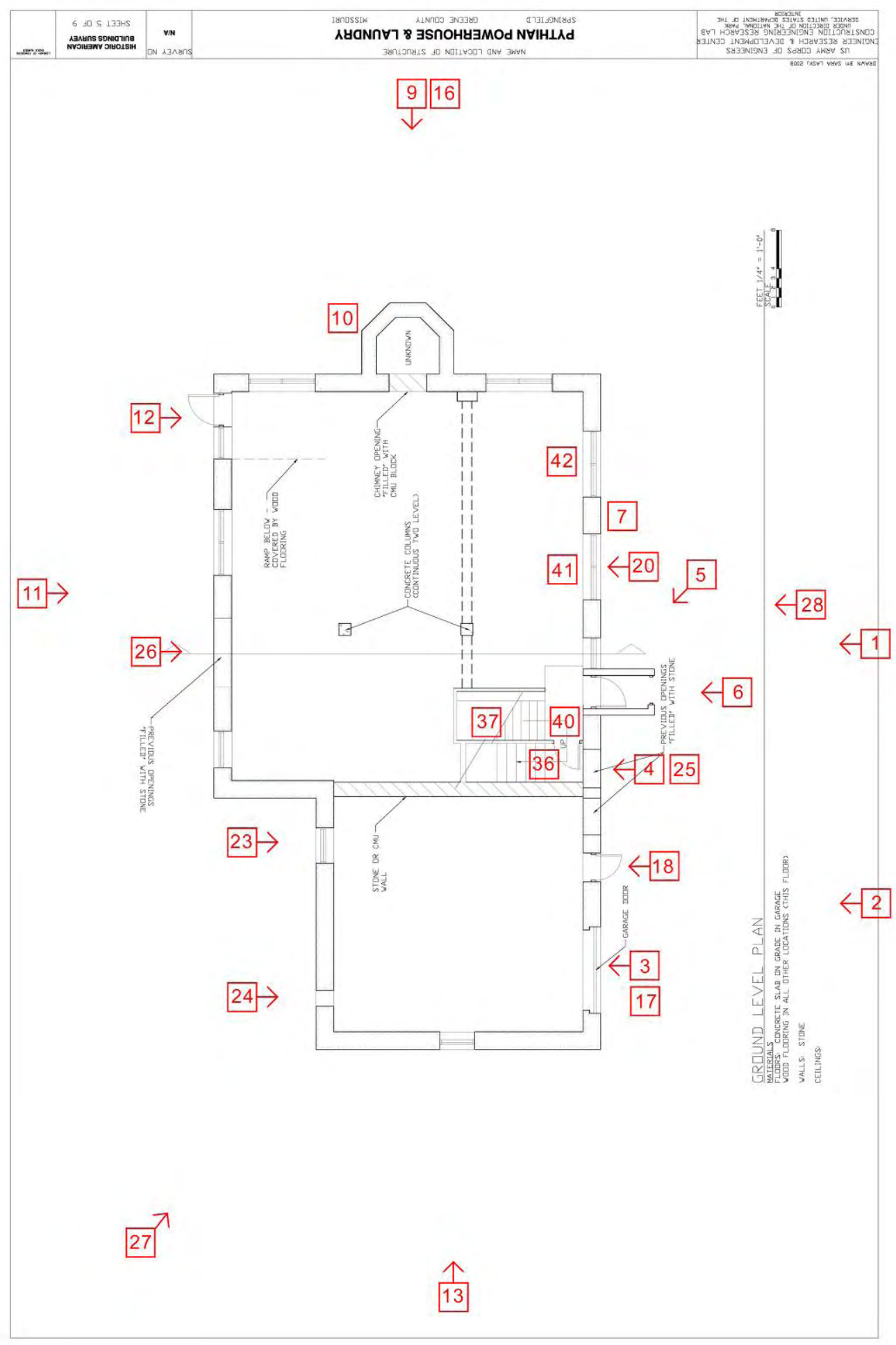

First Floor Photograph Locations 
PYTHIAN POWERHOUSE AND LAUNDRY

PHOTOGRAPHS (page 22)

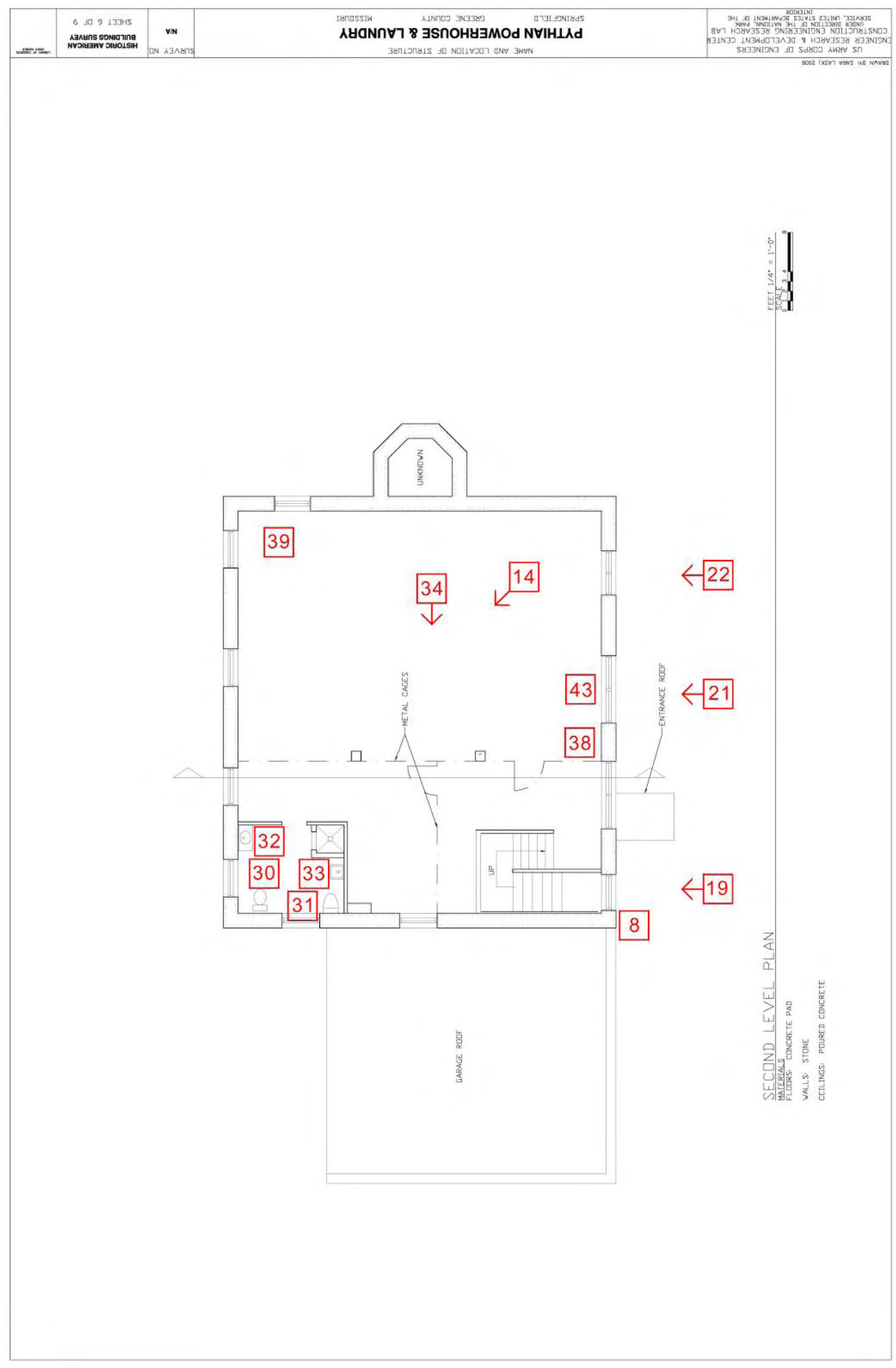

Second Floor Photograph Locations 


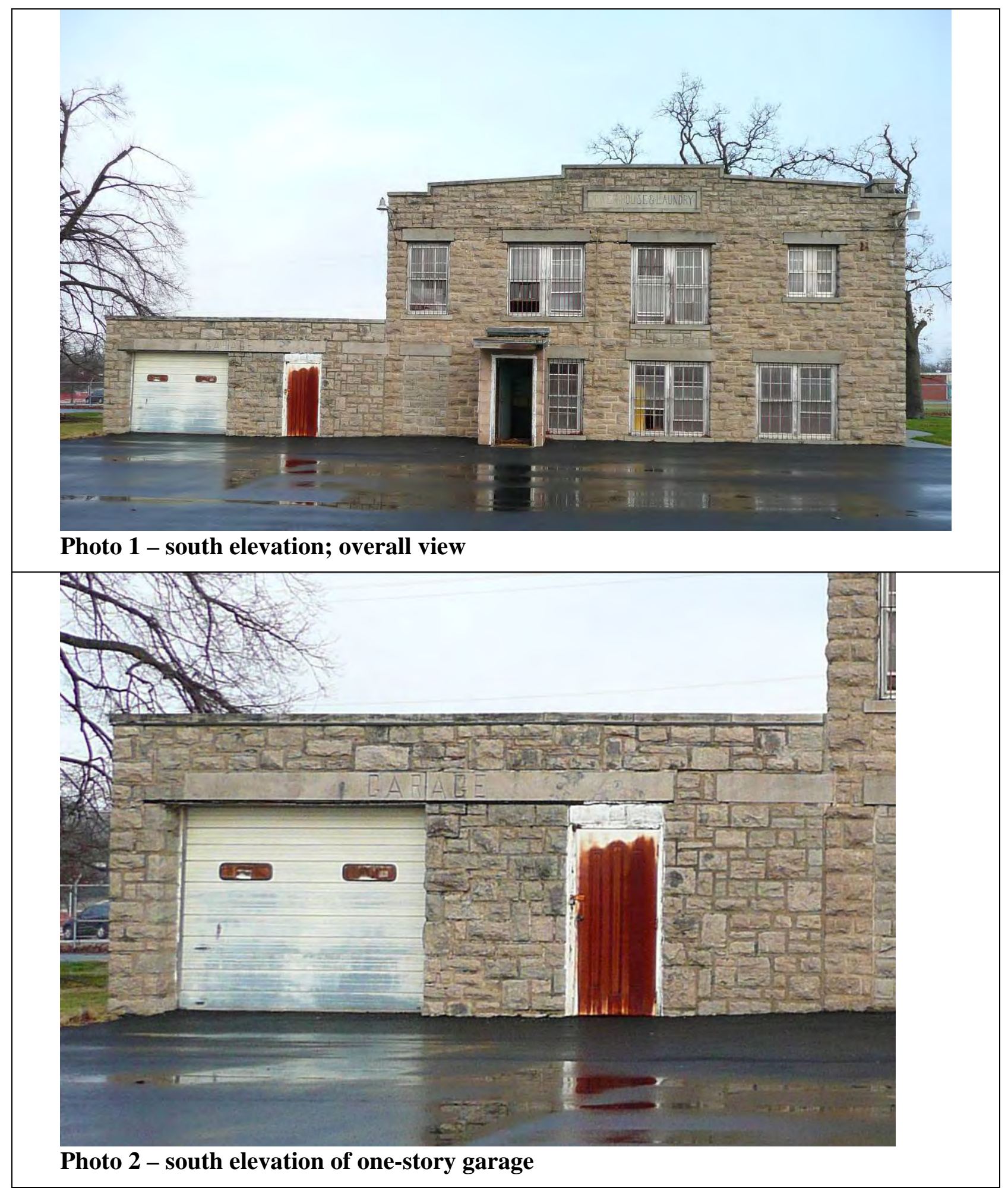


PYTHIAN POWERHOUSE AND LAUNDRY

PHOTOGRAPHS (page 24)

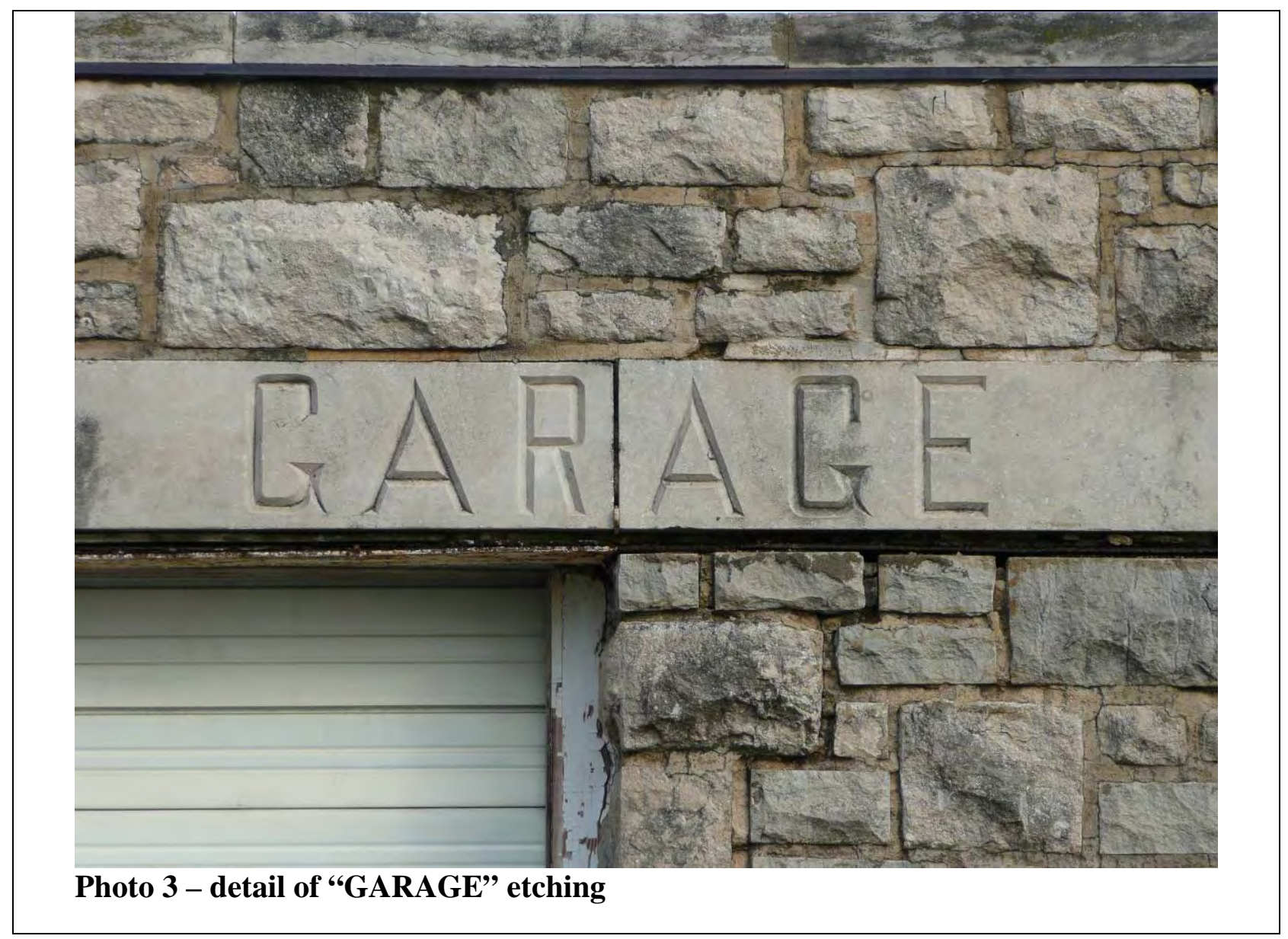




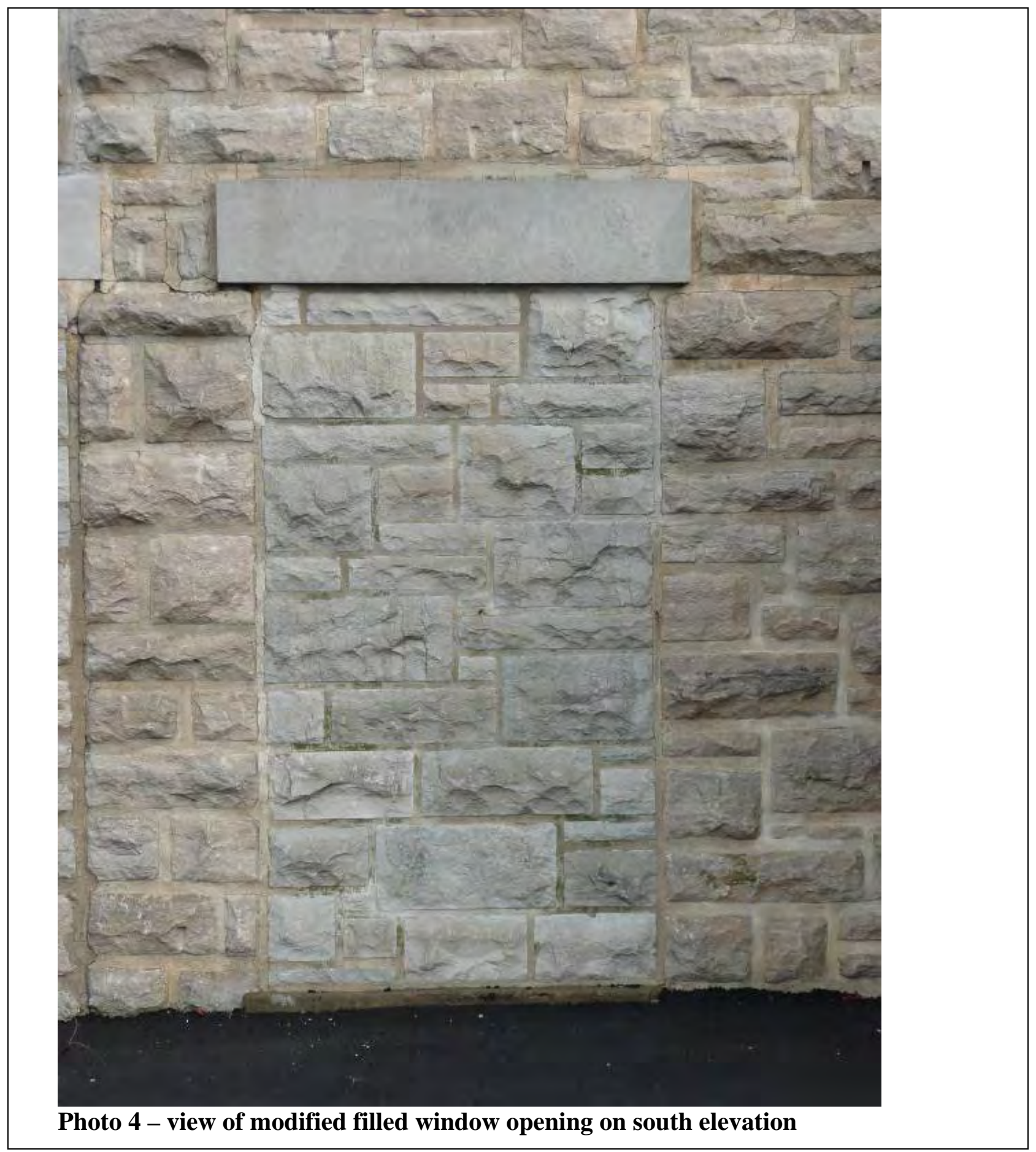




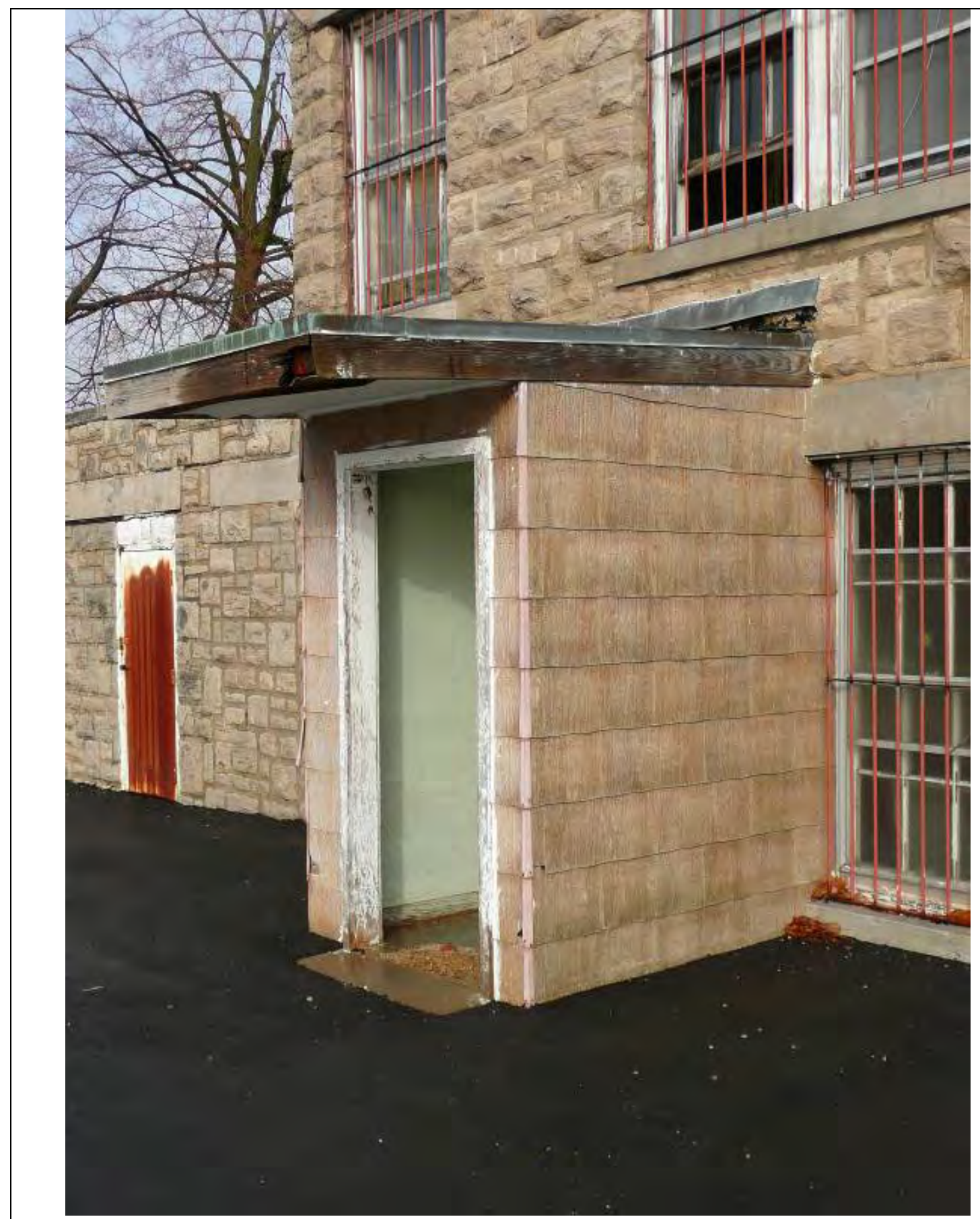

Photo 5 - close-up of vestibule addition on south elevation 


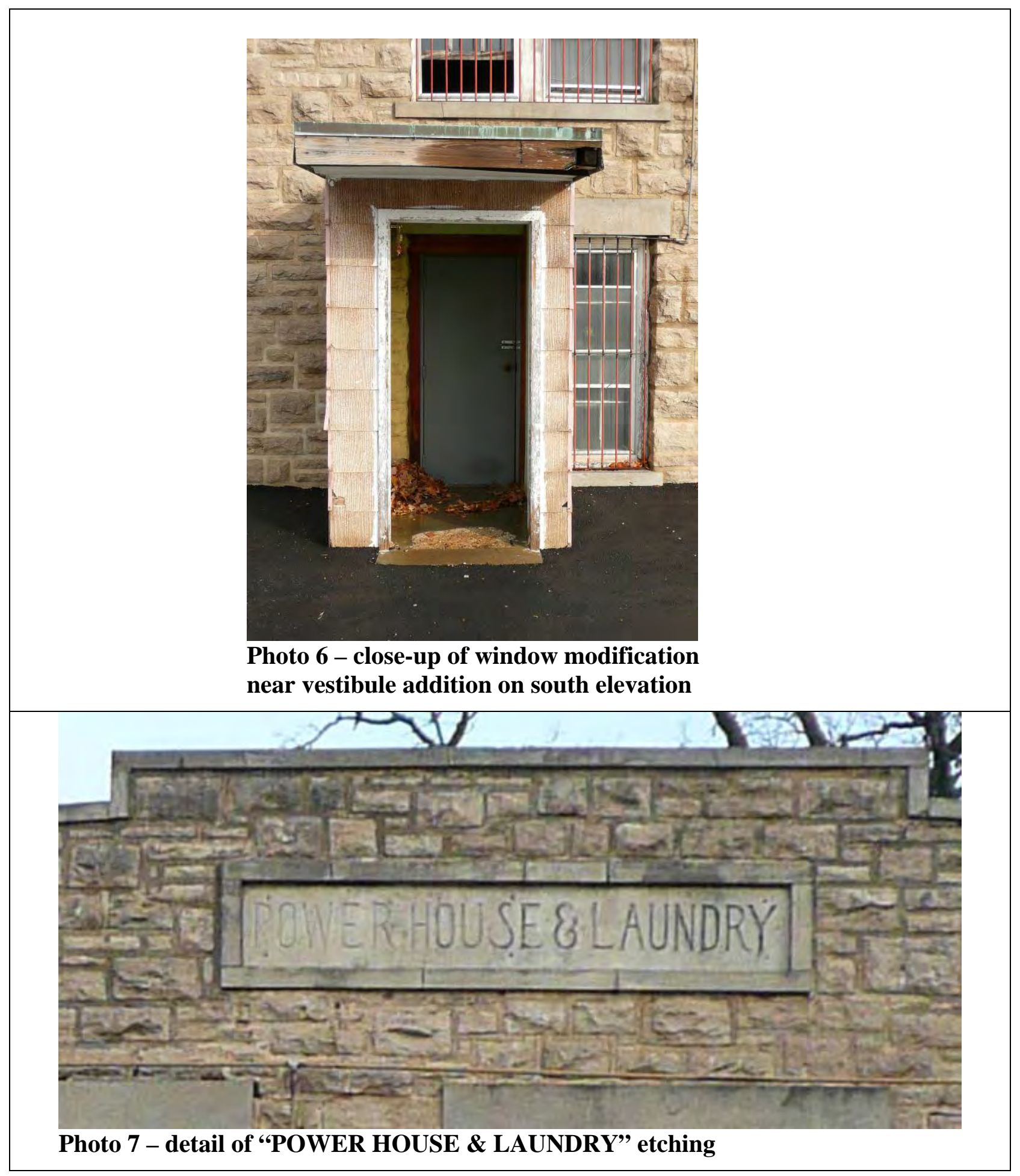




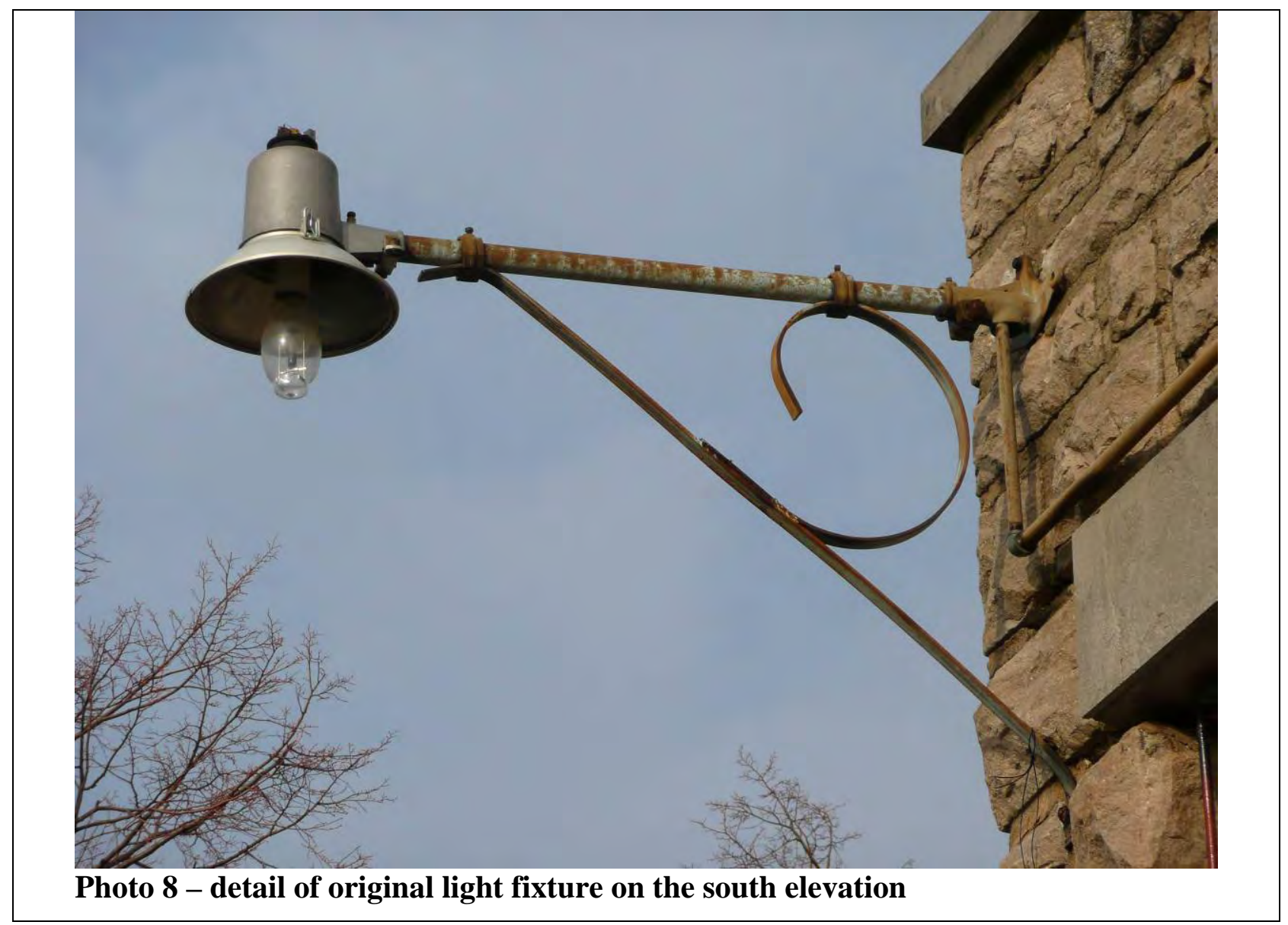




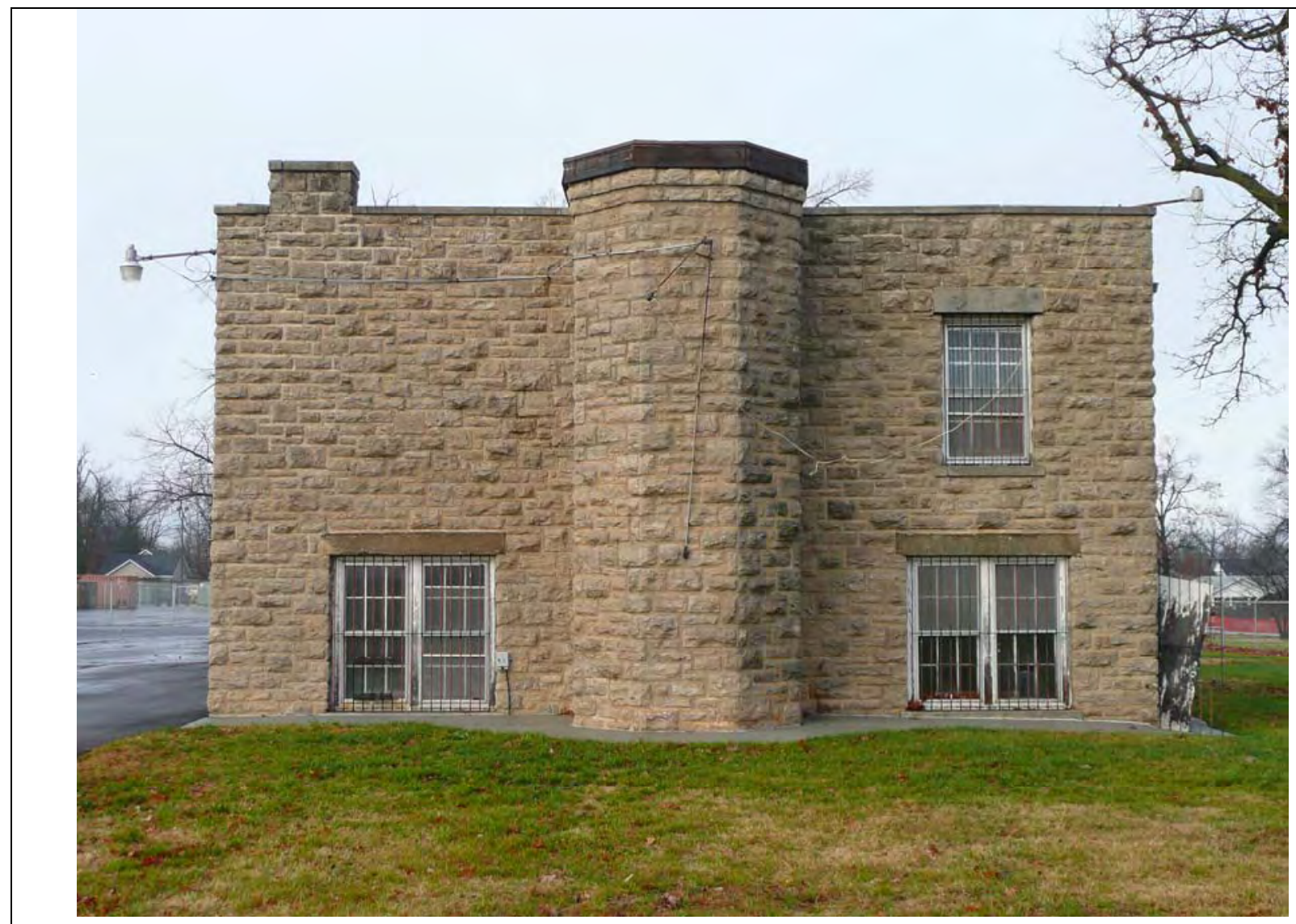

Photo 9 - east elevation; overall view

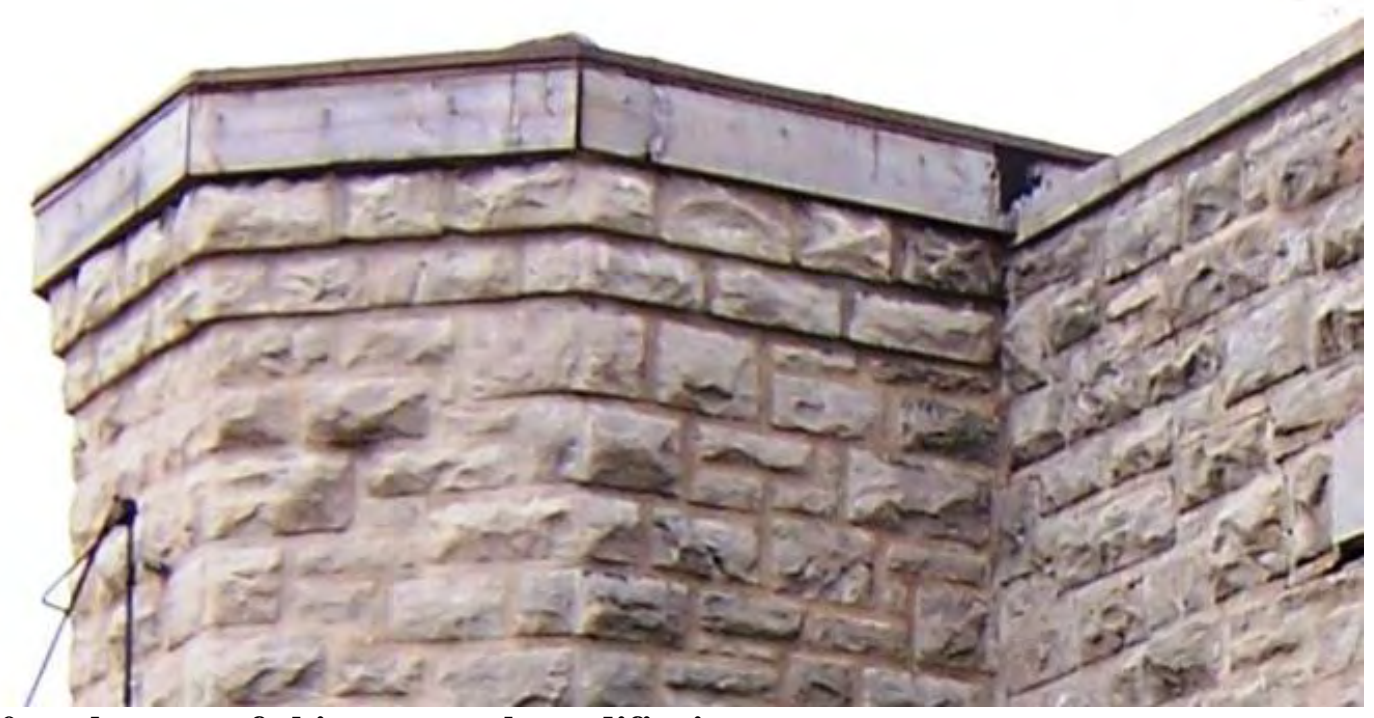

Photo 10 - close-up of chimney stack modificaiton 
PYTHIAN POWERHOUSE AND LAUNDRY

PHOTOGRAPHS (page 30)

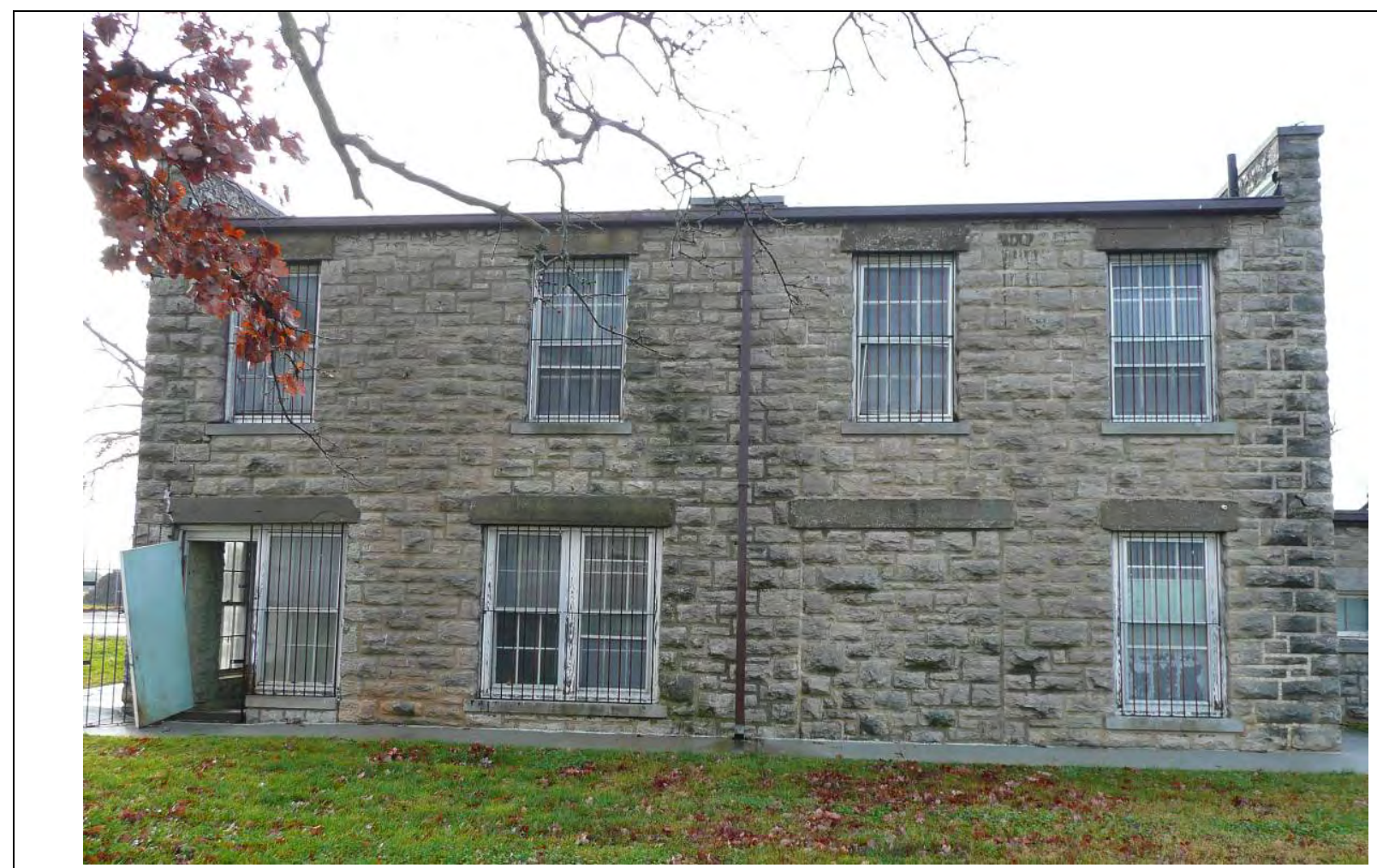

Photo 11 - left side of the north elevation; overall view

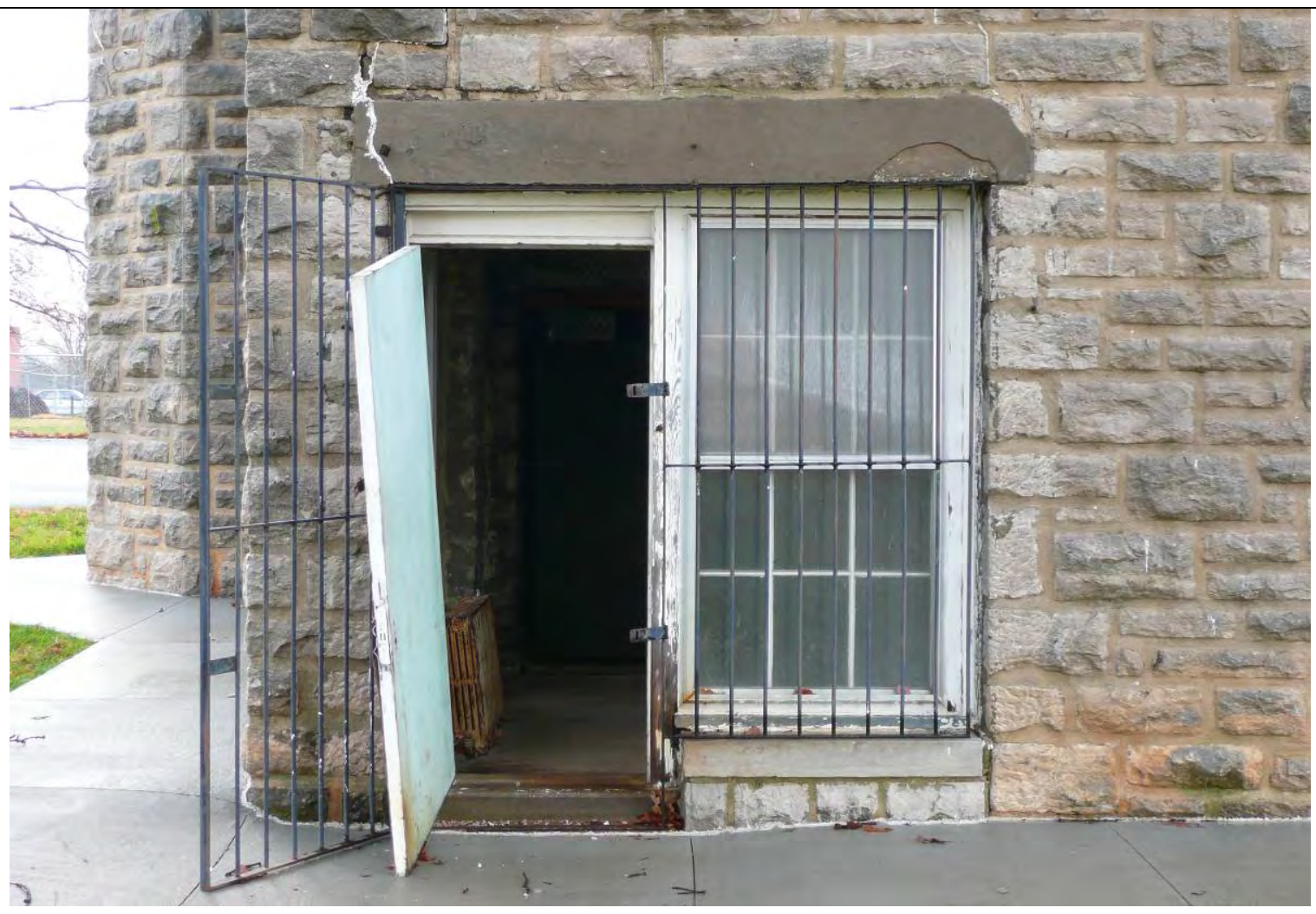

Photo 12 - close-up of window modification on north elevation 
PYTHIAN POWERHOUSE AND LAUNDRY

PHOTOGRAPHS (page 31)

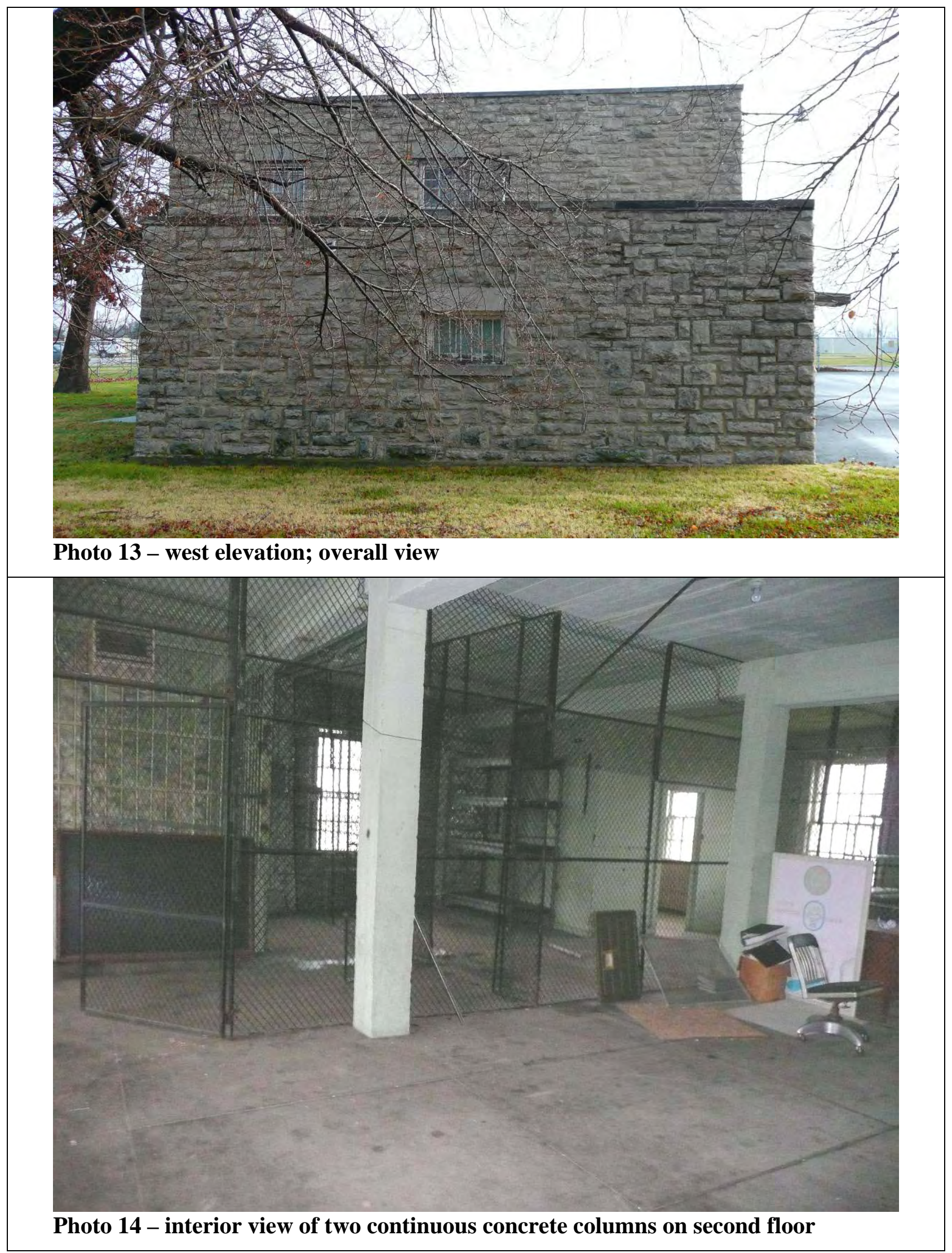


PYTHIAN POWERHOUSE AND LAUNDRY

PHOTOGRAPHS (page 32)

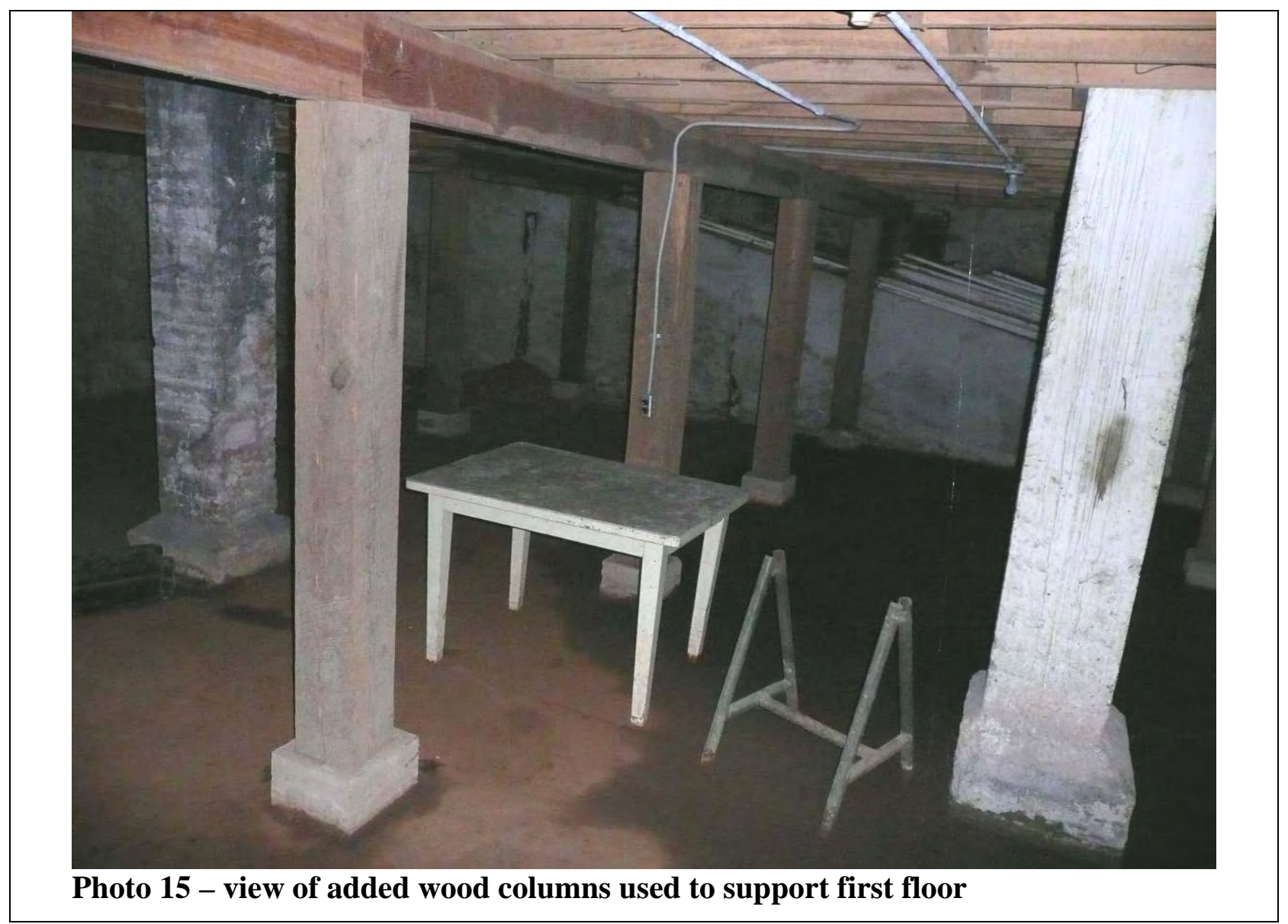




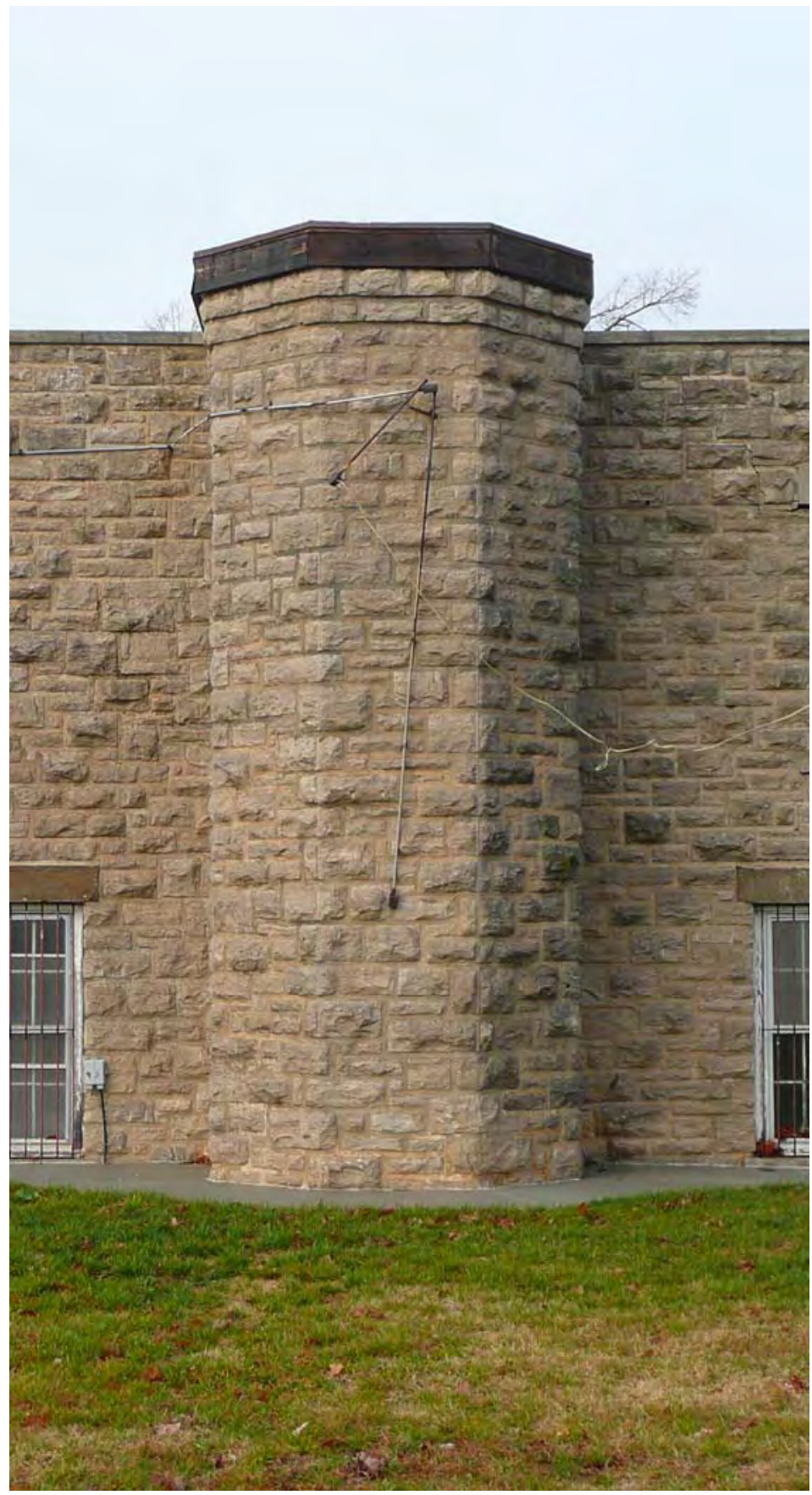




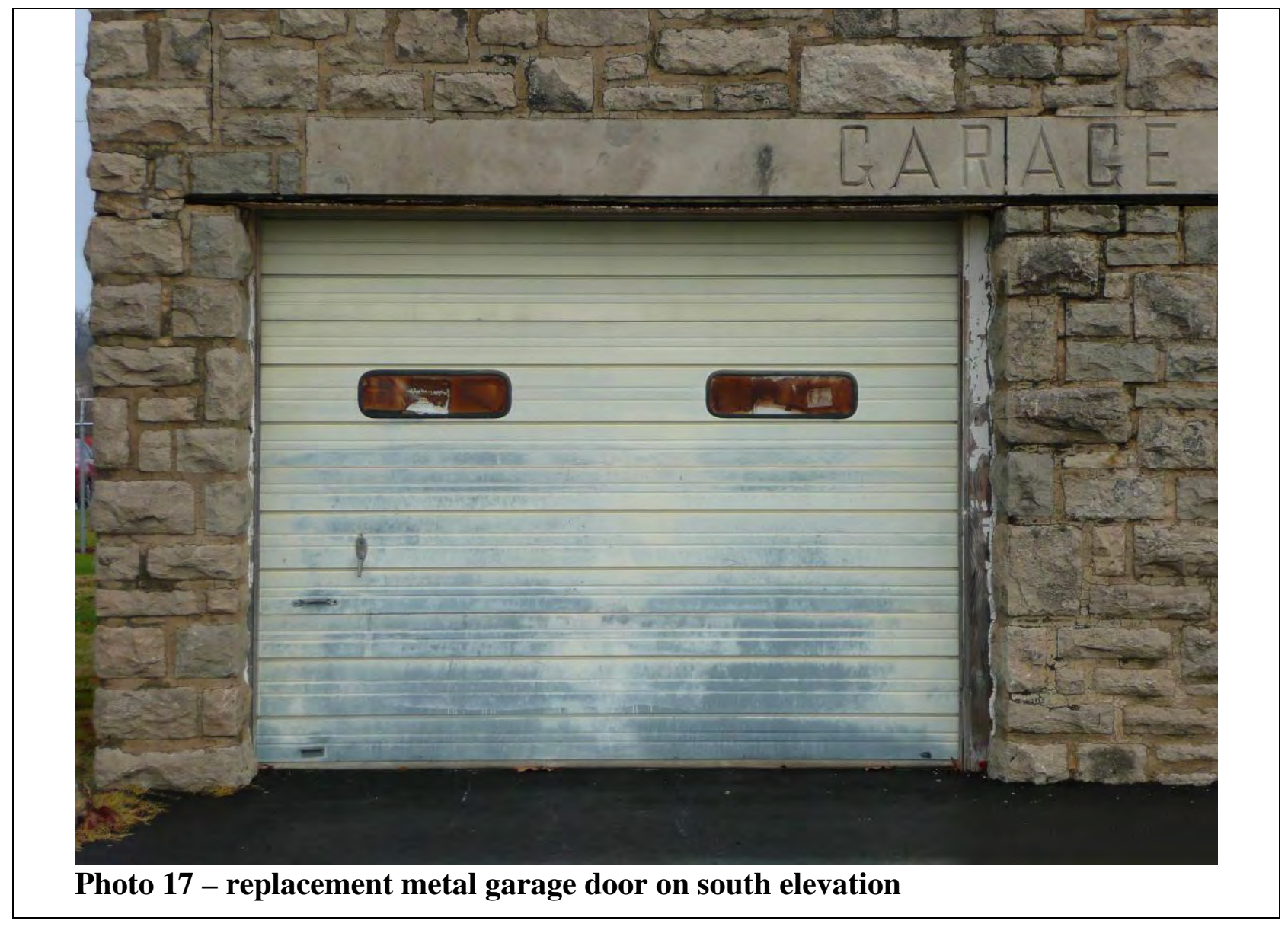




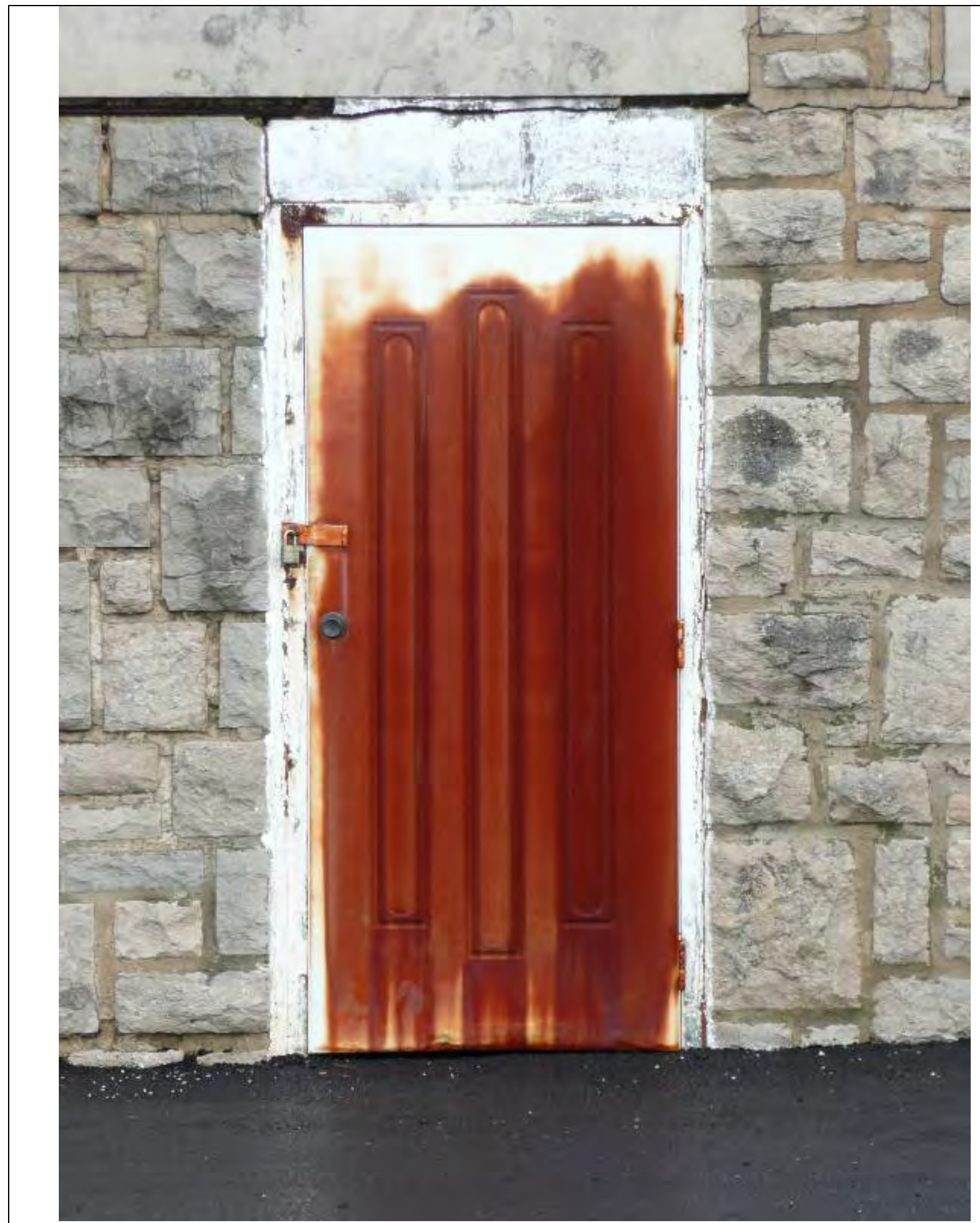

Photo 18 - metal entry door into garage 
PYTHIAN POWERHOUSE AND LAUNDRY

PHOTOGRAPHS (page 36)

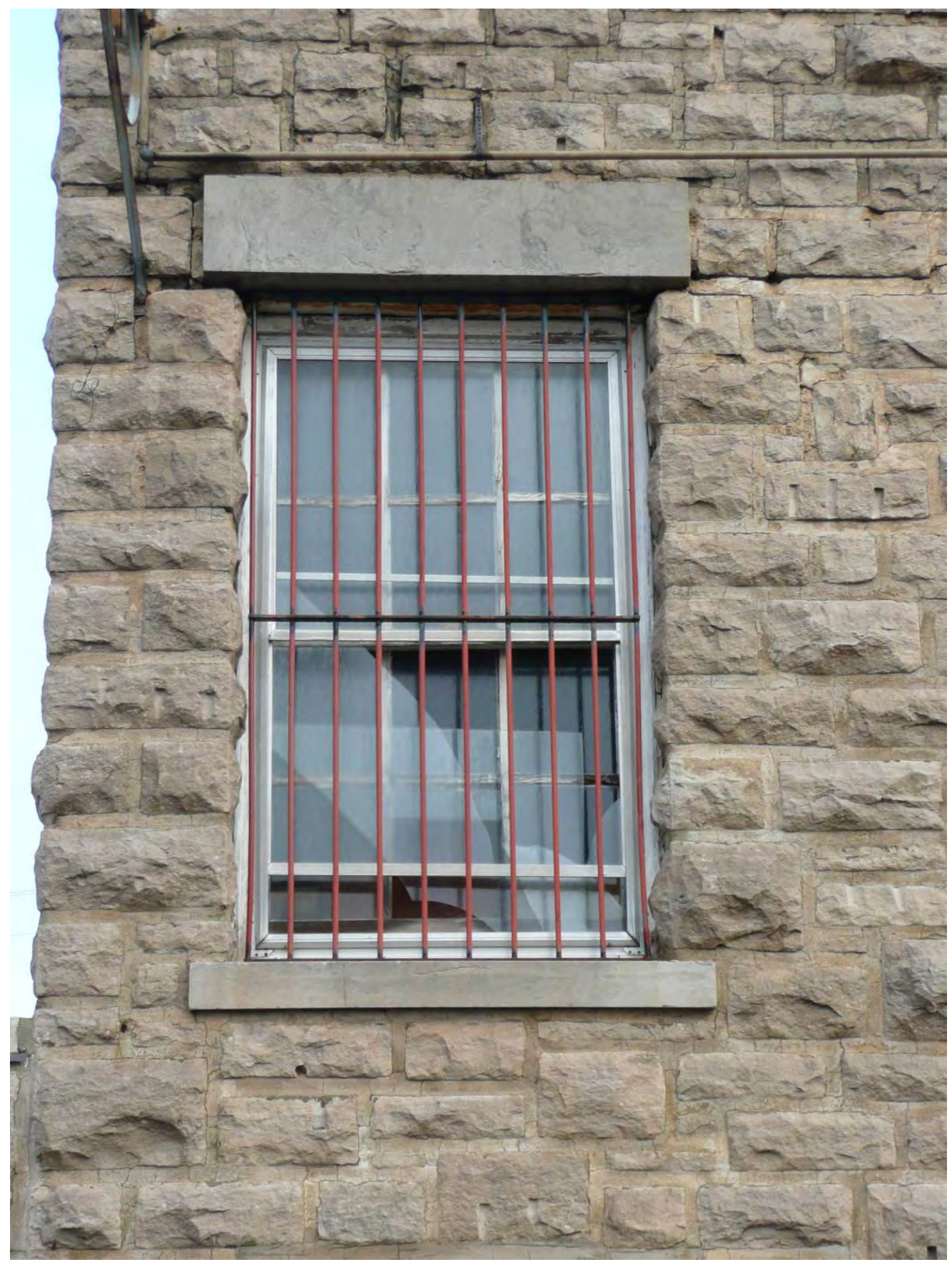

Photo 19 - Type 1 window 


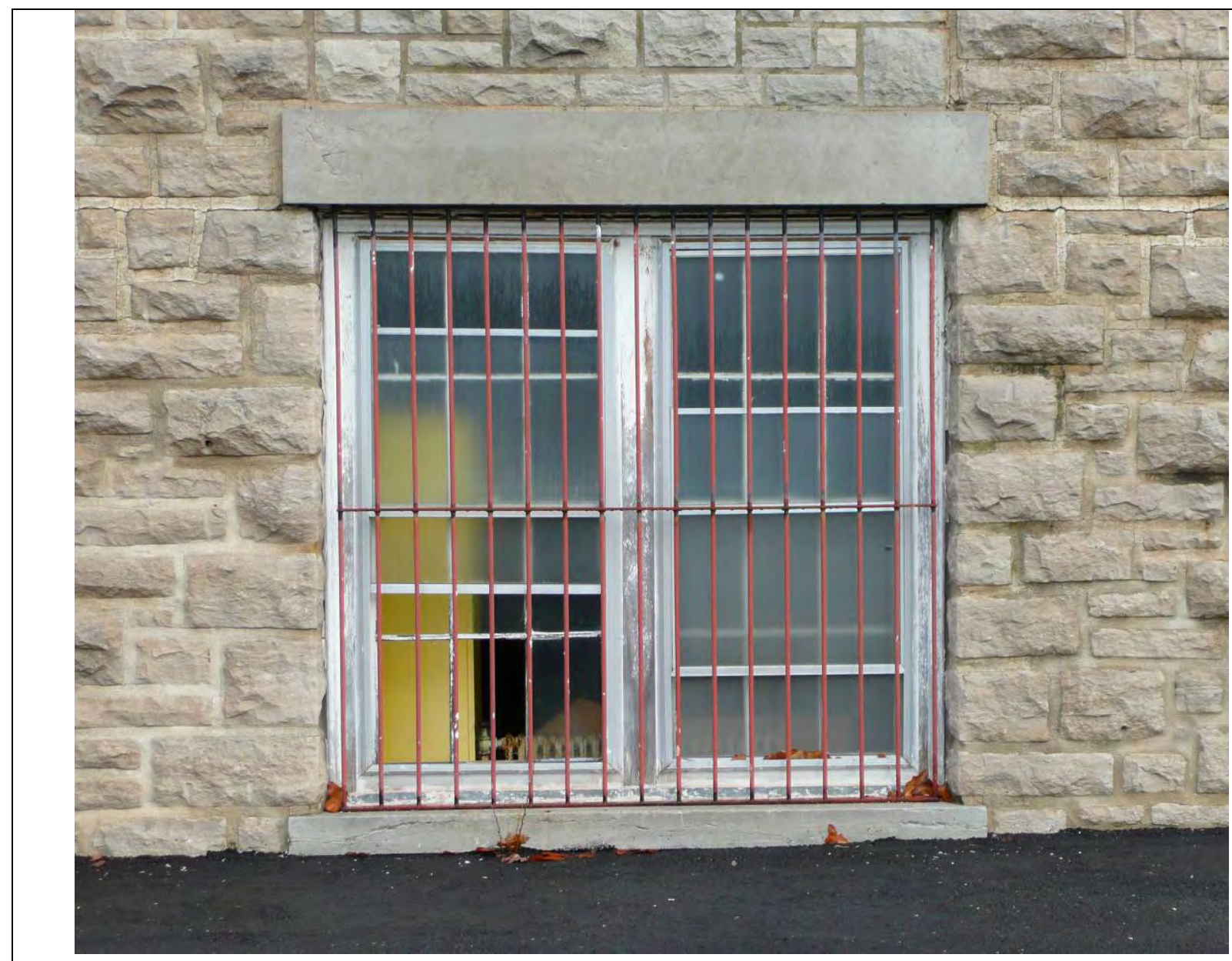

Photo 20 - Type 2 window 


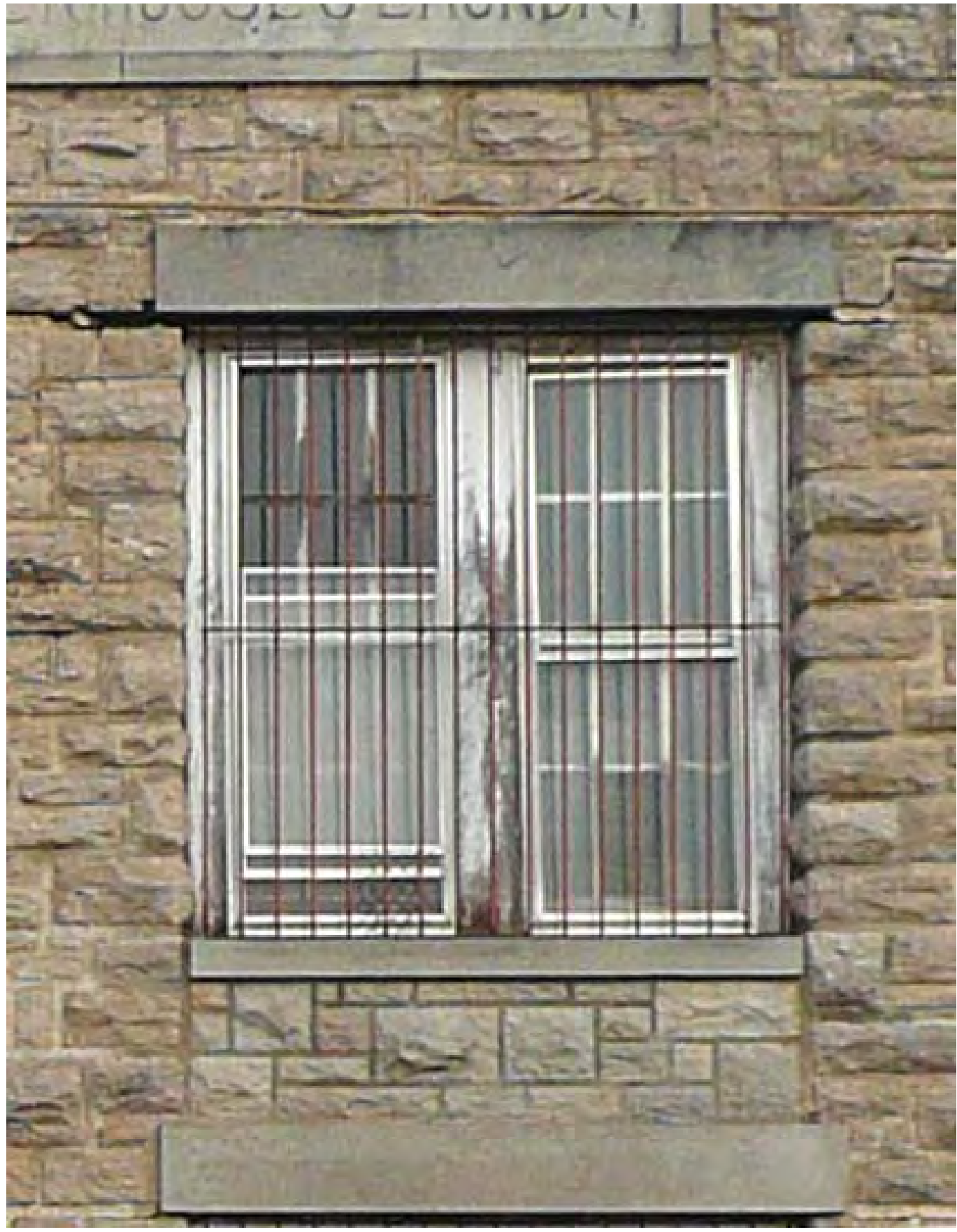

Photo 21 - Type 3 window 


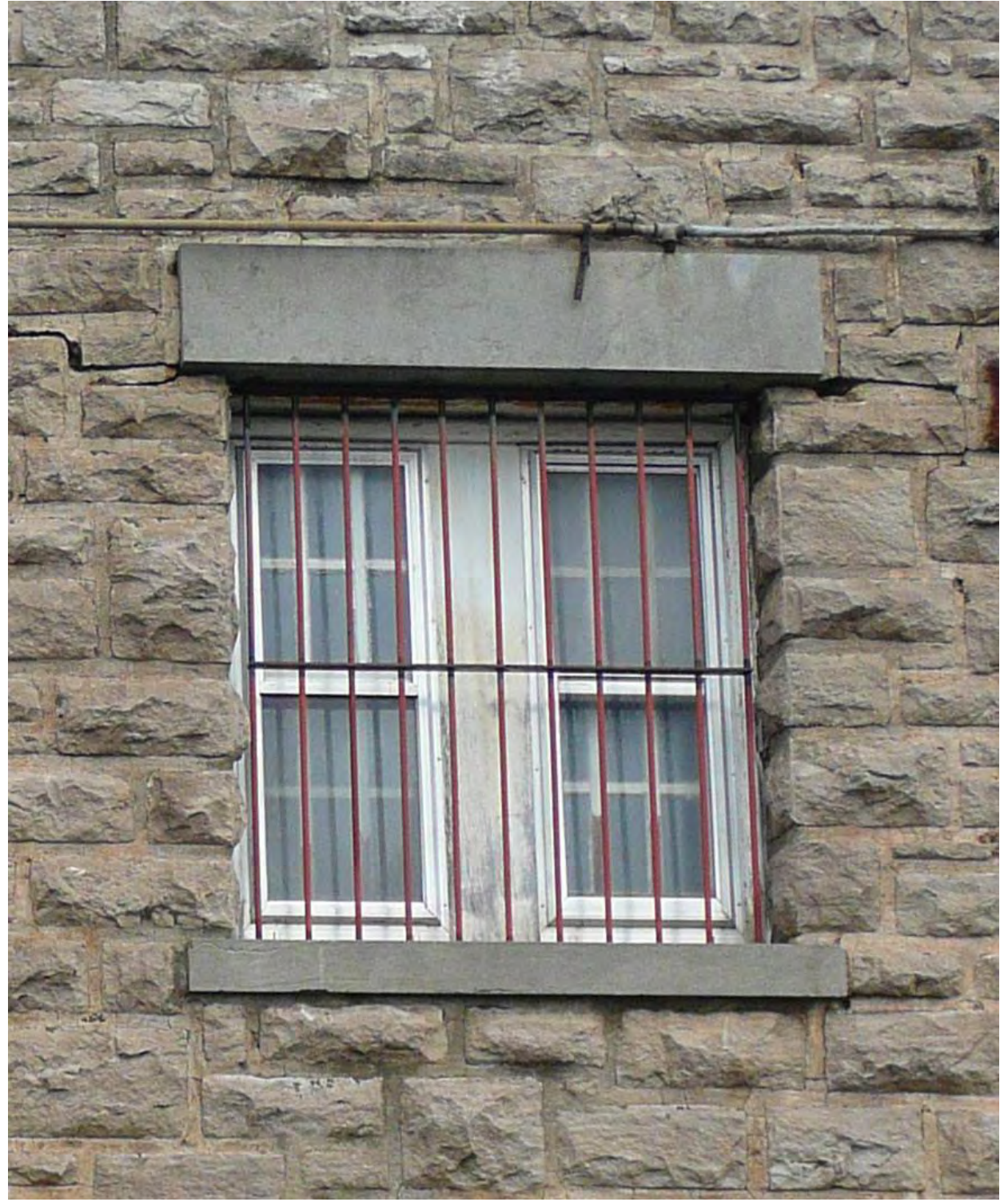

Photo 22 - Type 4 window 


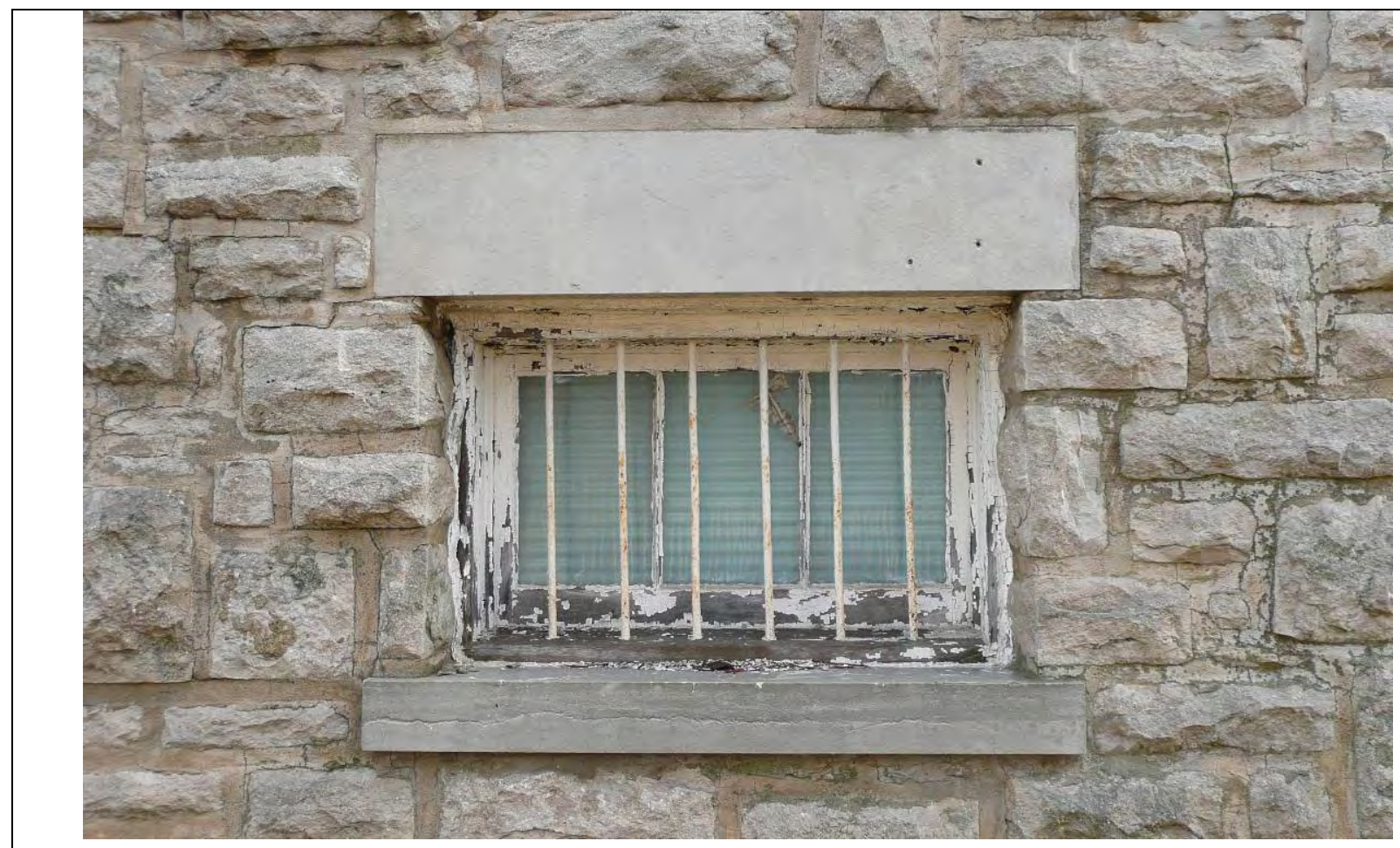

Photo 23 - Type 5 window

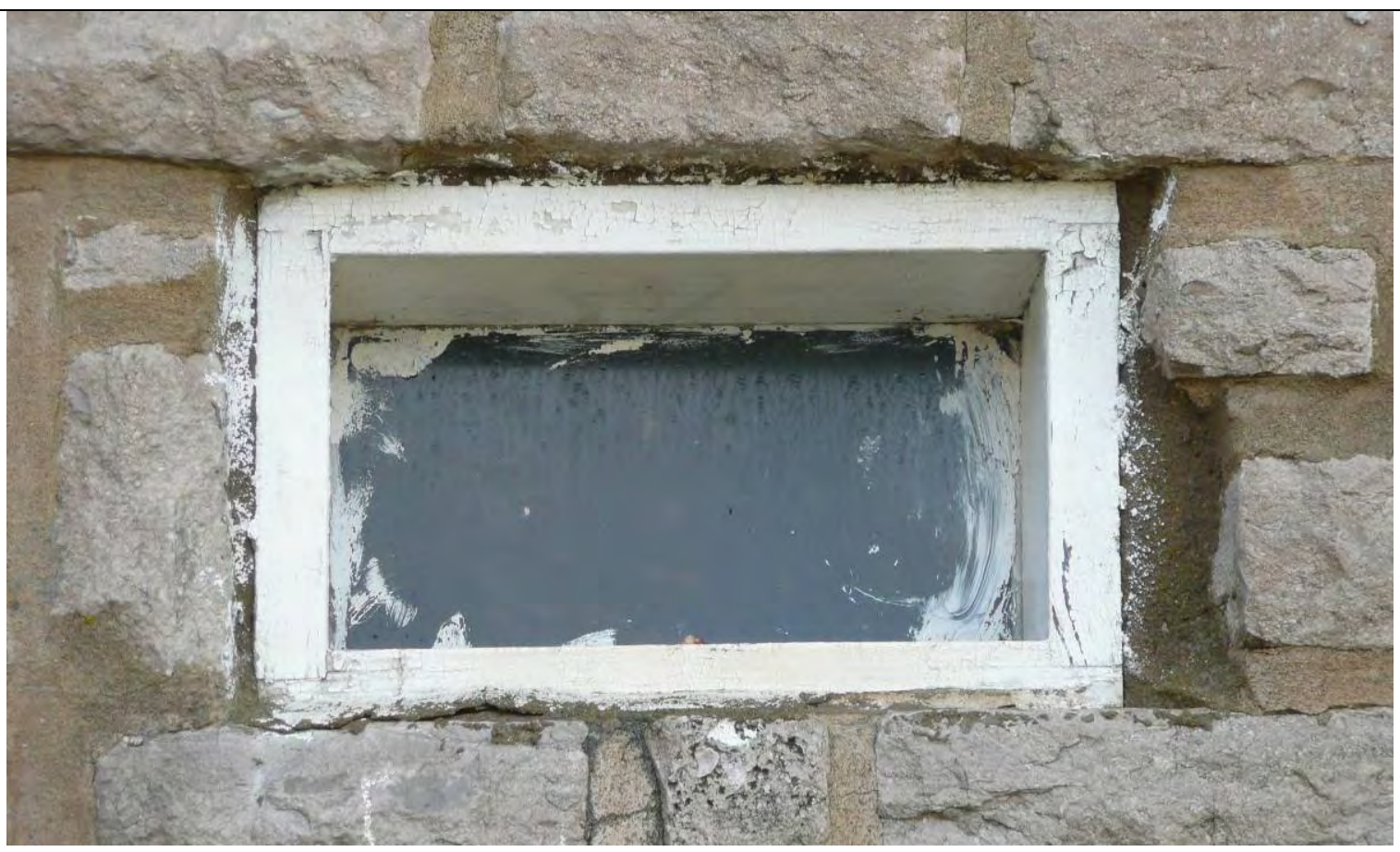

Photo 24 - Type 6 window 


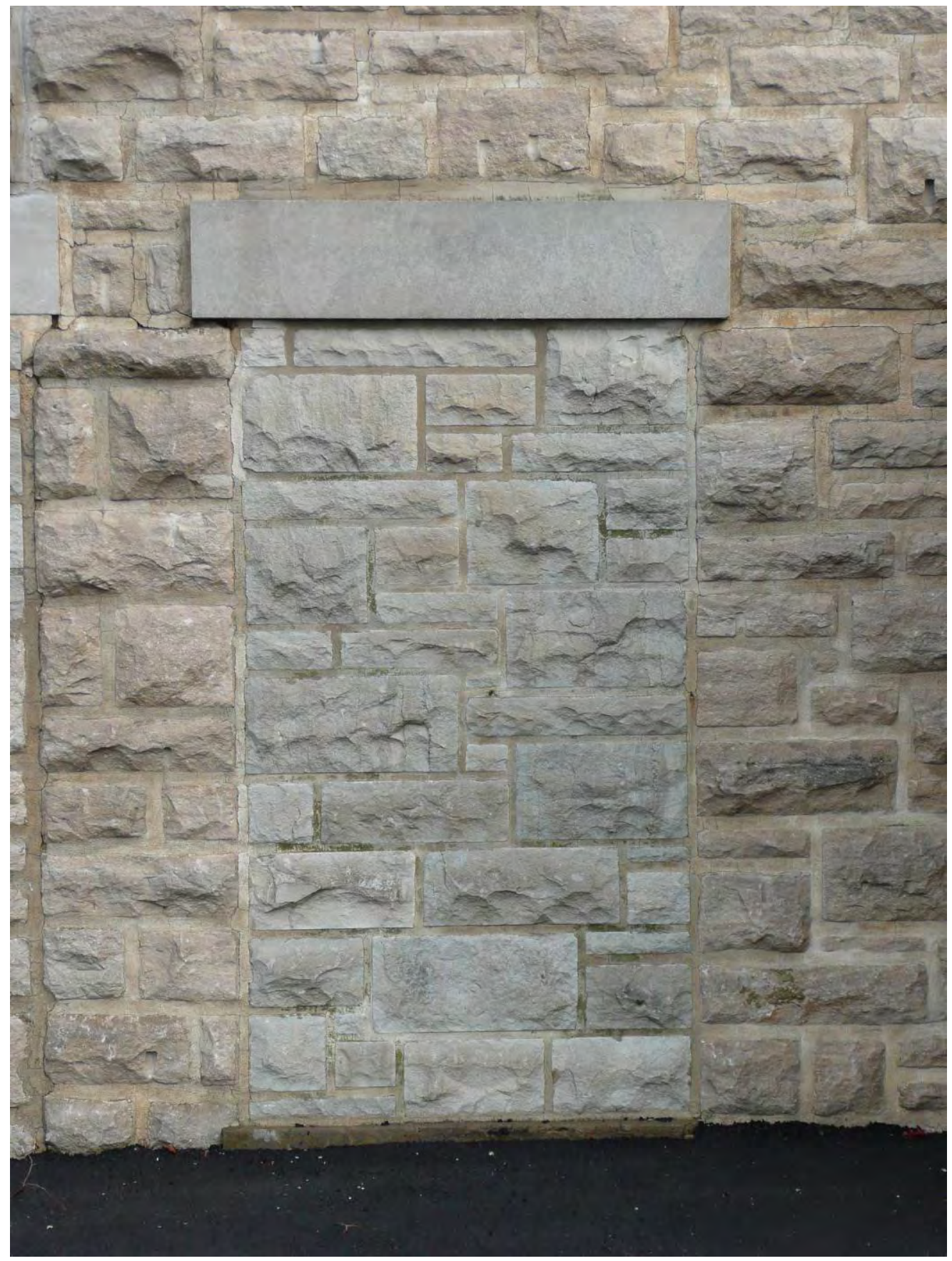

Photo 25 - Type 7 window or door 
PYTHIAN POWERHOUSE AND LAUNDRY

PHOTOGRAPHS (page 42)

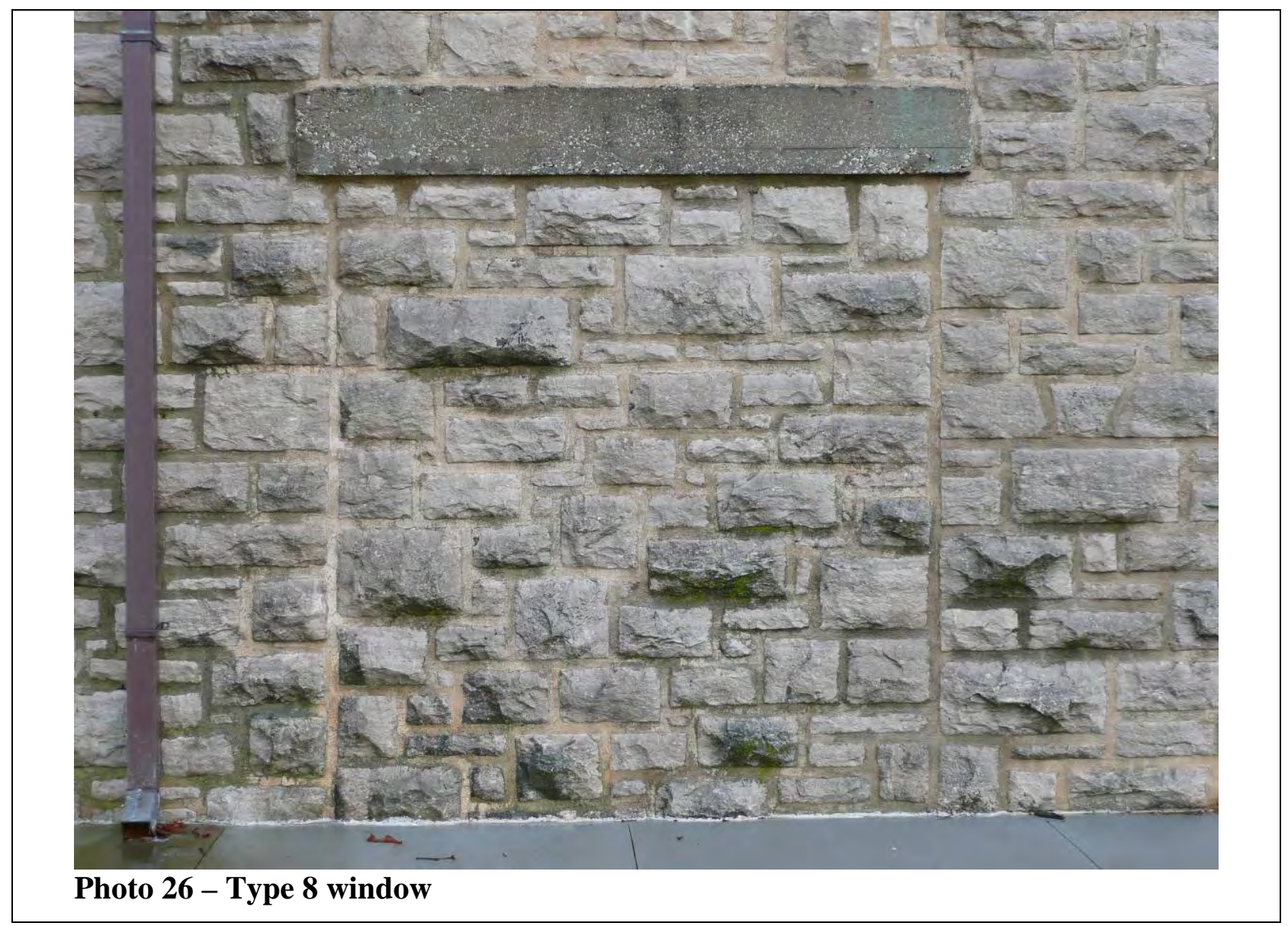




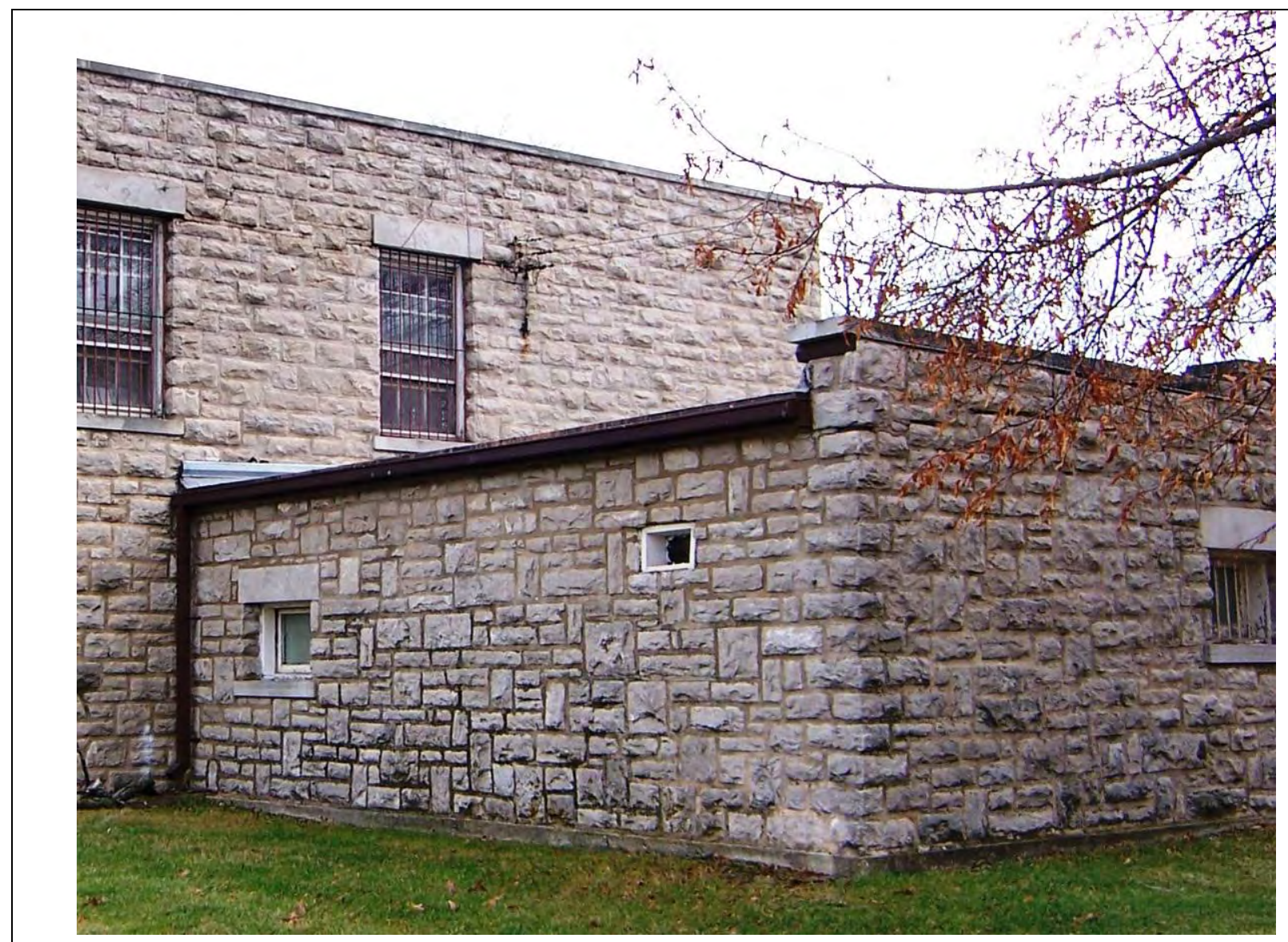

Photo 27 - parapet detail on west elevation of one-story garage

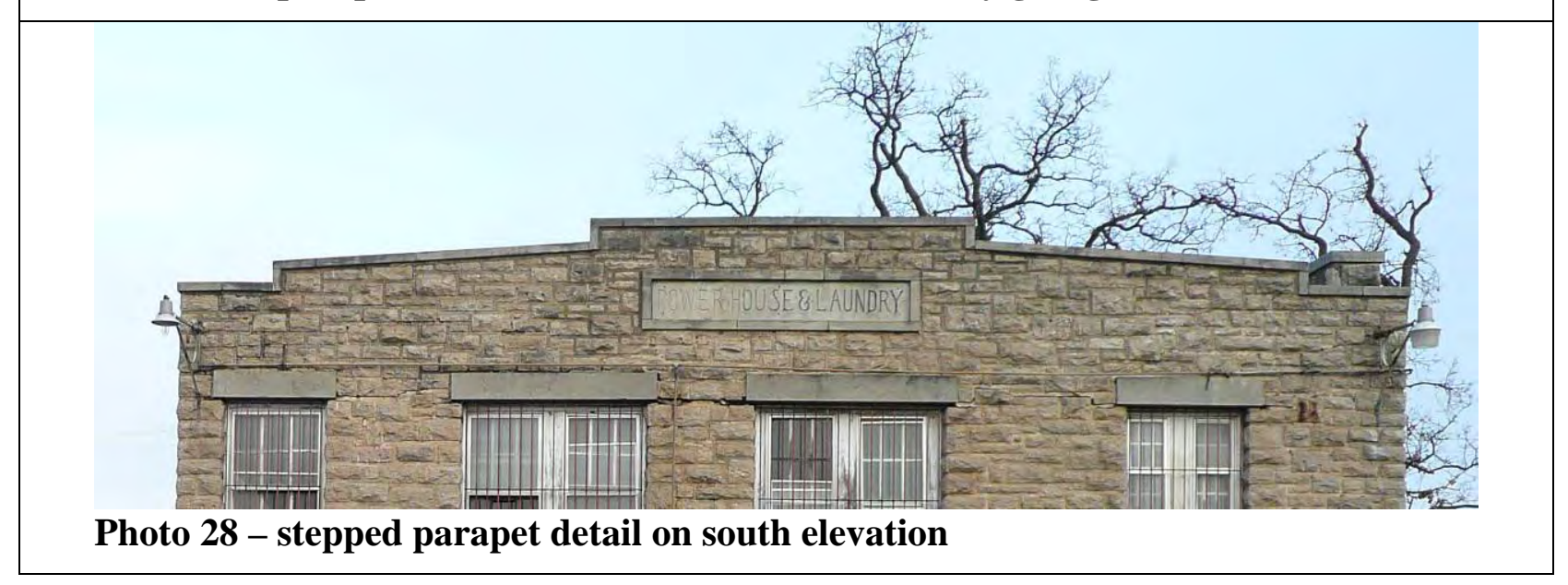


PYTHIAN POWERHOUSE AND LAUNDRY INTERIOR PHOTOGRAPHS (page 44)

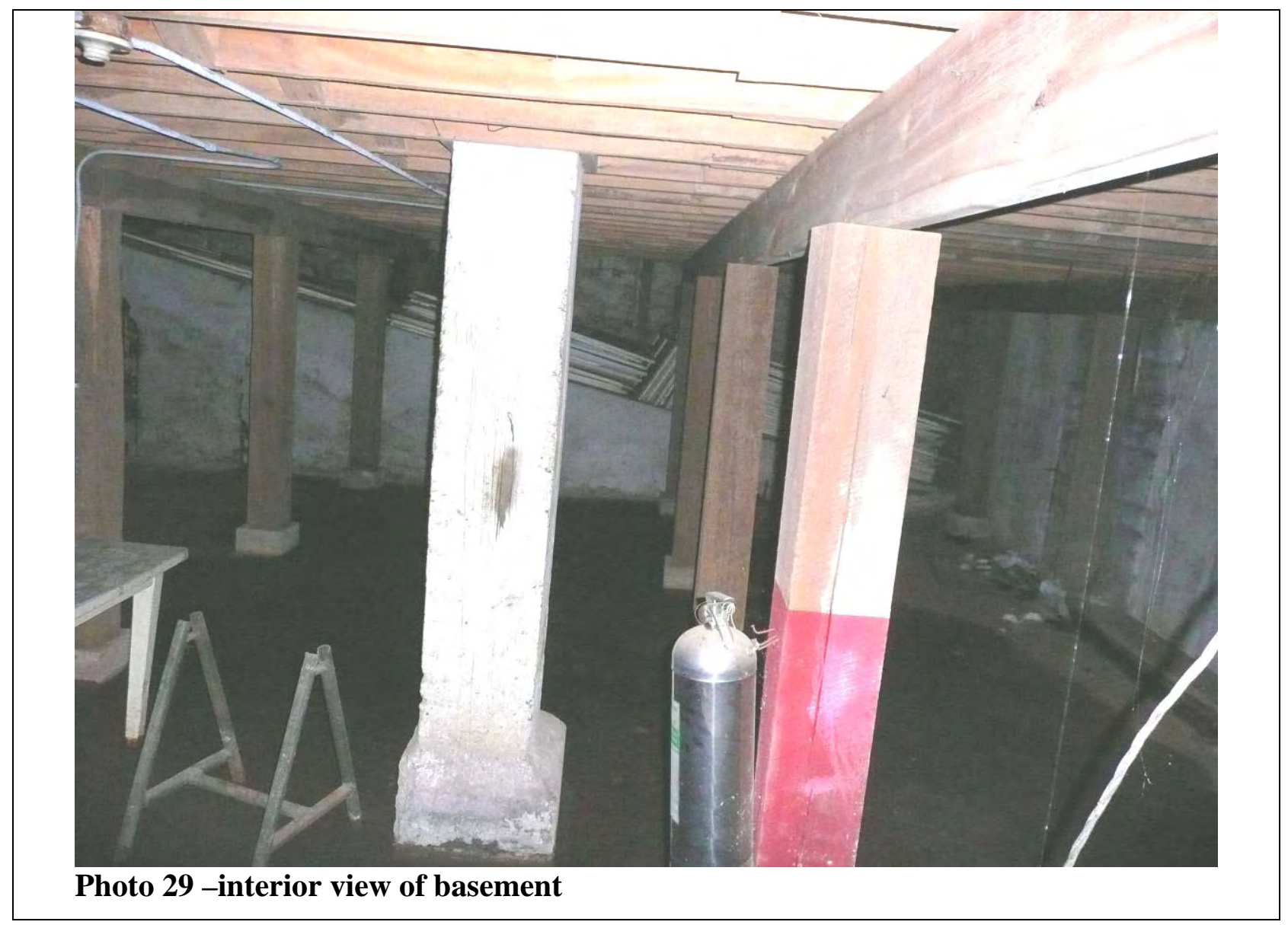


PYTHIAN POWERHOUSE AND LAUNDRY

INTERIOR PHOTOGRAPHS (page 45)

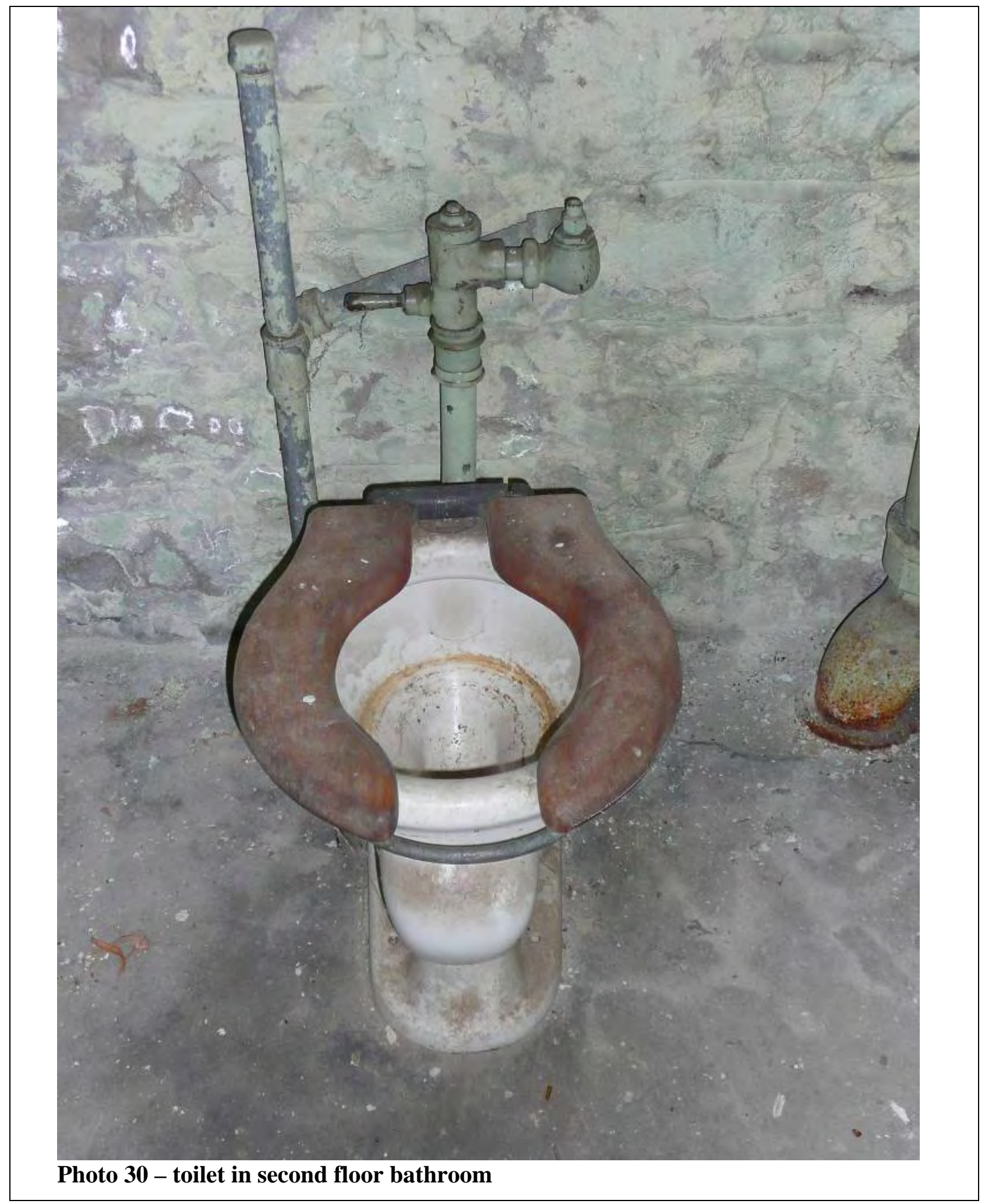


PYTHIAN POWERHOUSE AND LAUNDRY INTERIOR PHOTOGRAPHS (page 46)

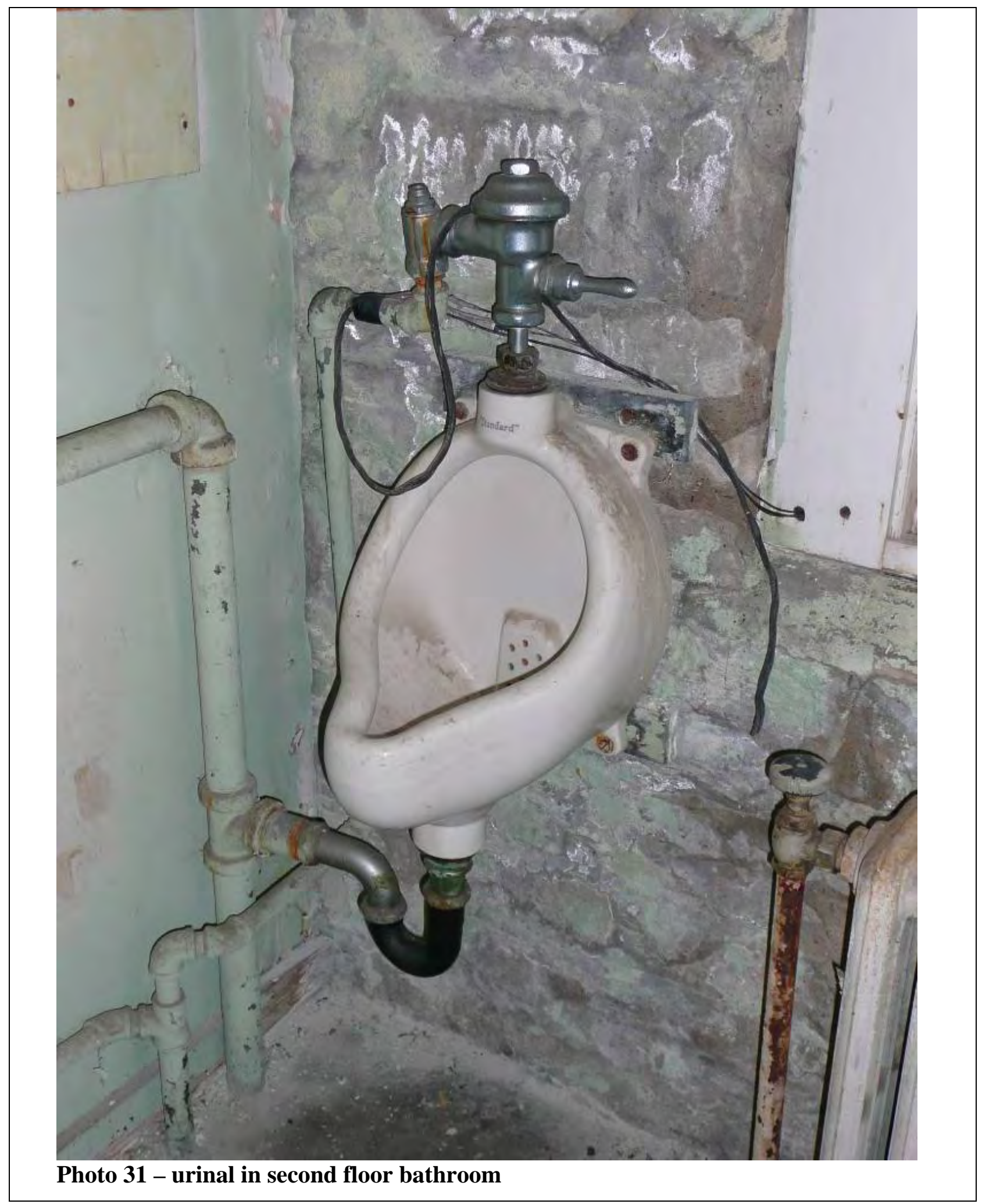


PYTHIAN POWERHOUSE AND LAUNDRY INTERIOR PHOTOGRAPHS (page 47)

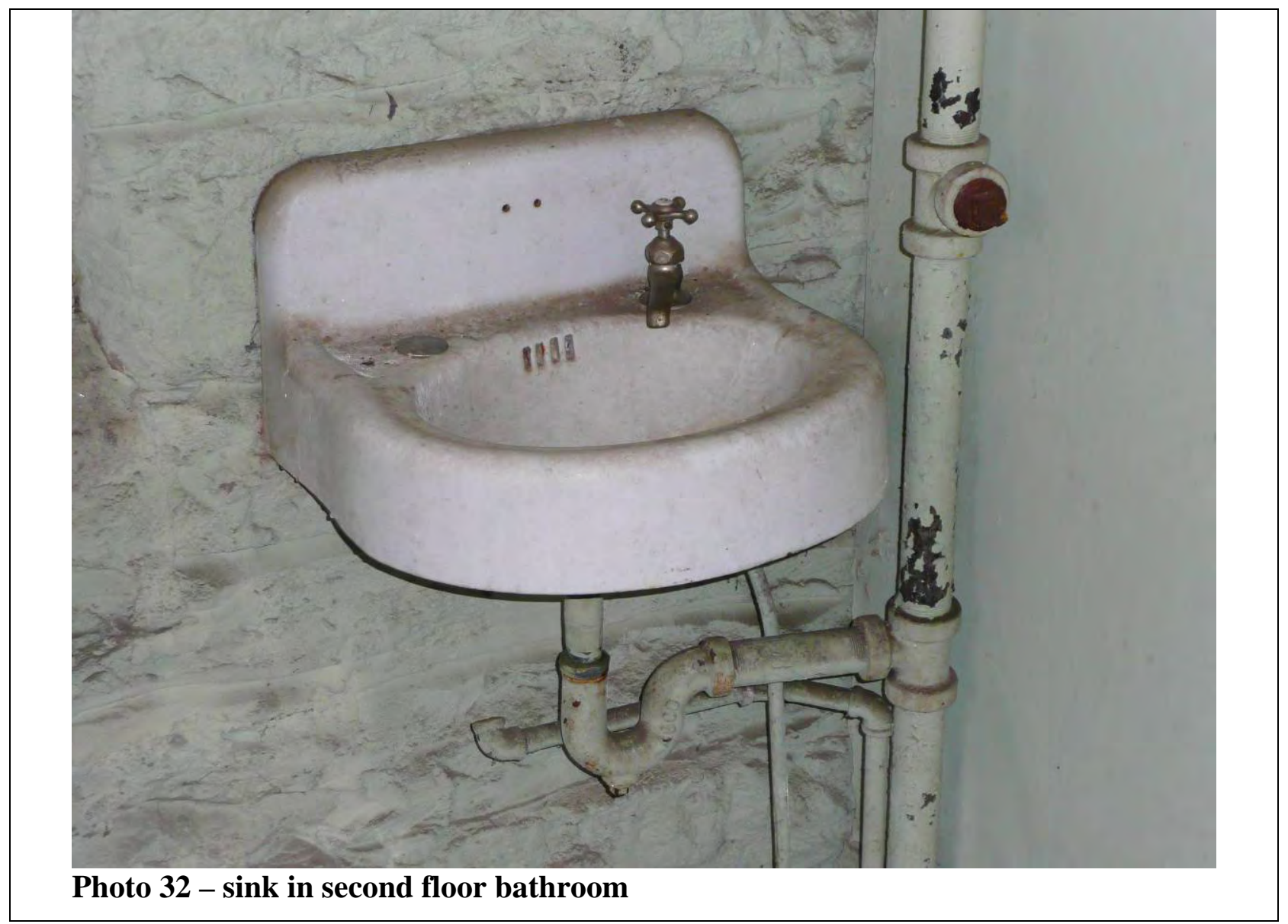


PYTHIAN POWERHOUSE AND LAUNDRY INTERIOR PHOTOGRAPHS (page 48)

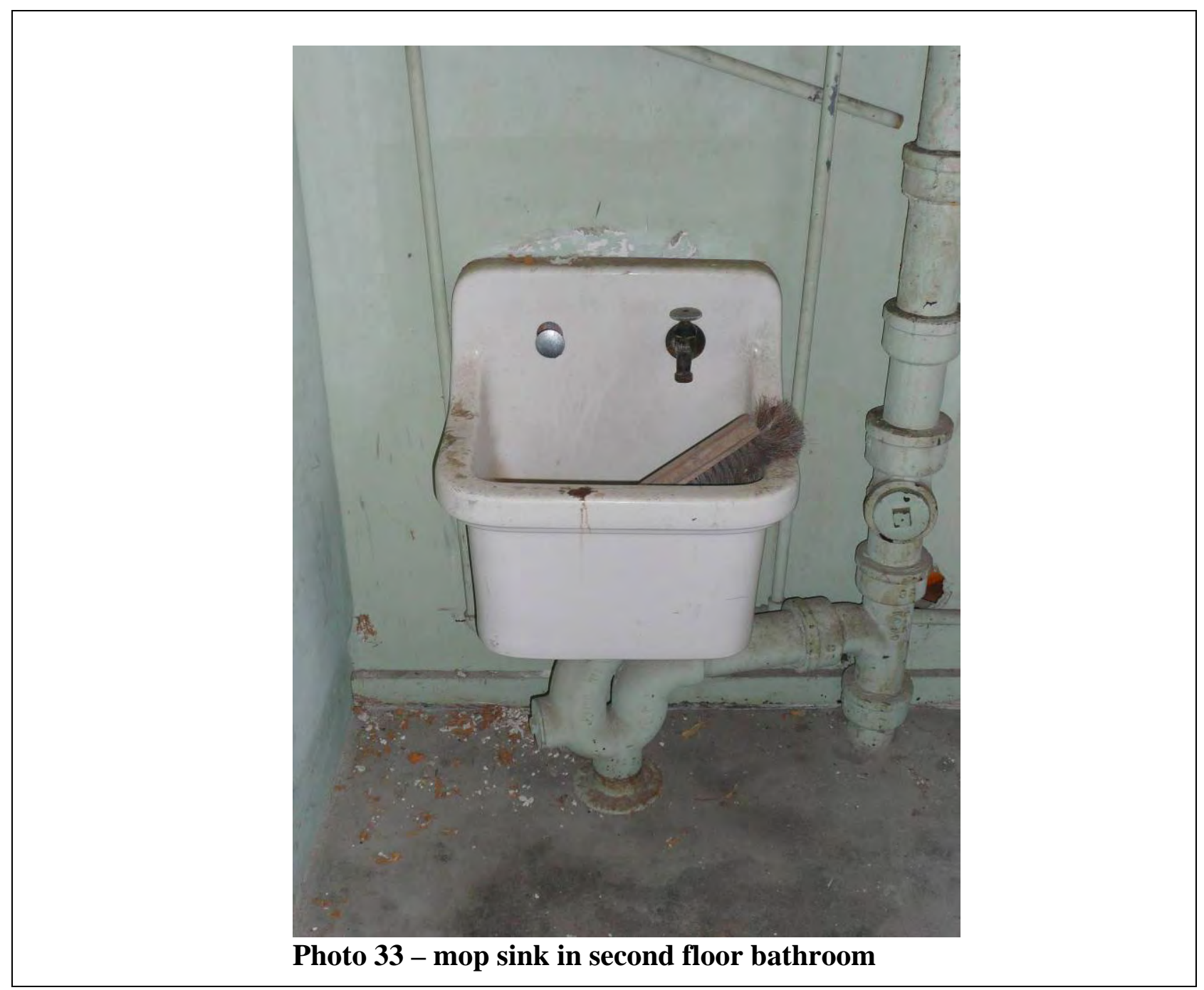


PYTHIAN POWERHOUSE AND LAUNDRY INTERIOR PHOTOGRAPHS (page 49)

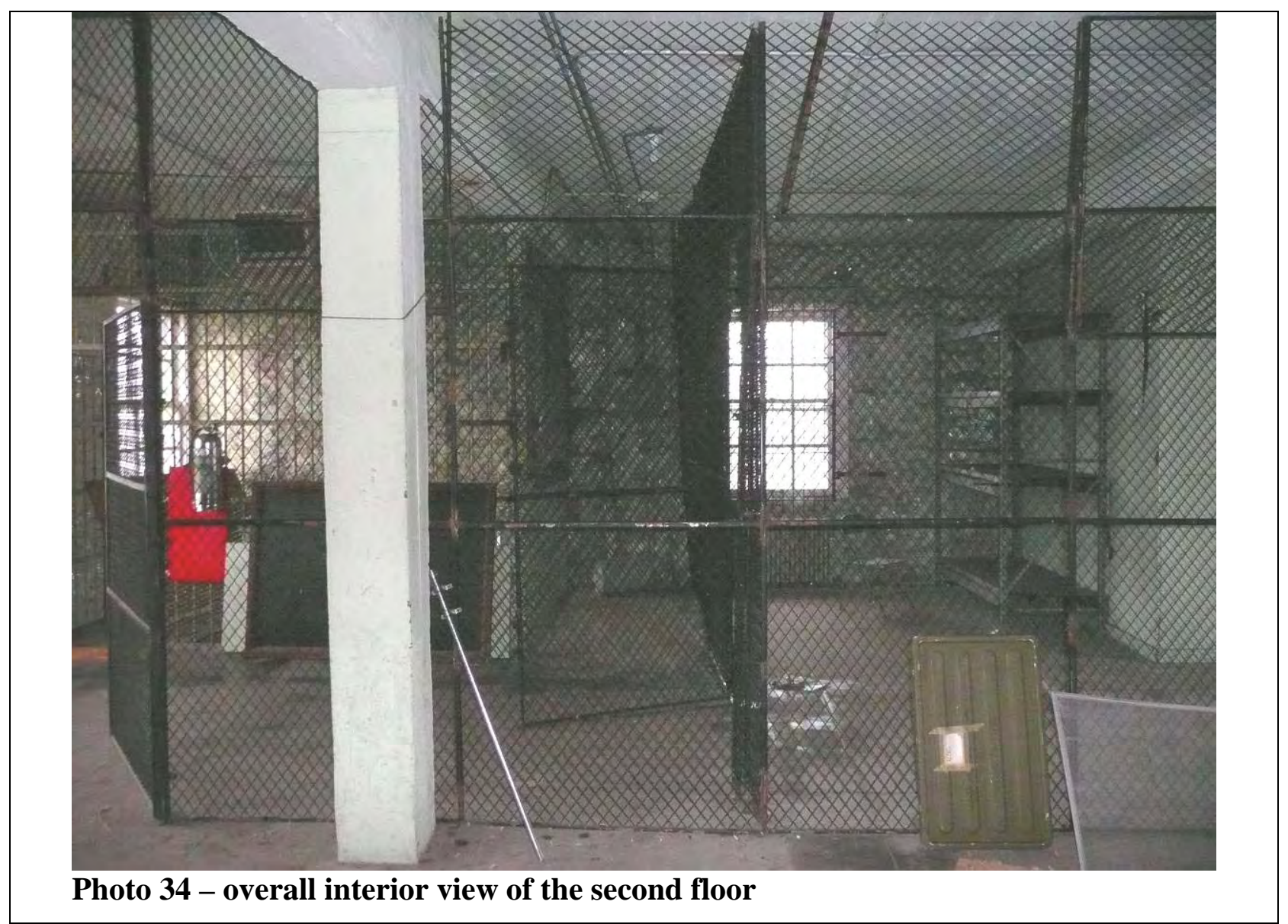




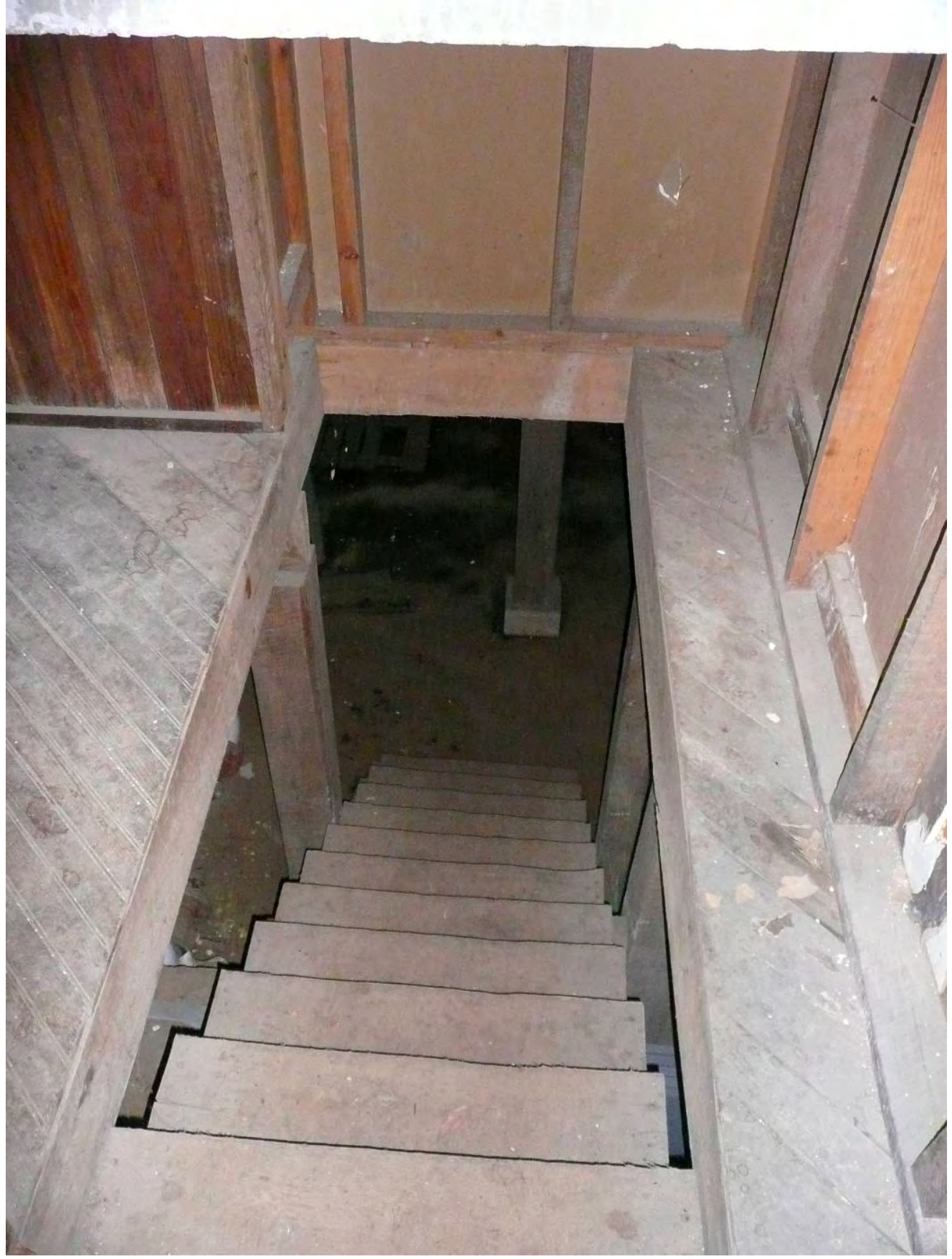

Photo 35 - view of wood stairs leading to the basement 


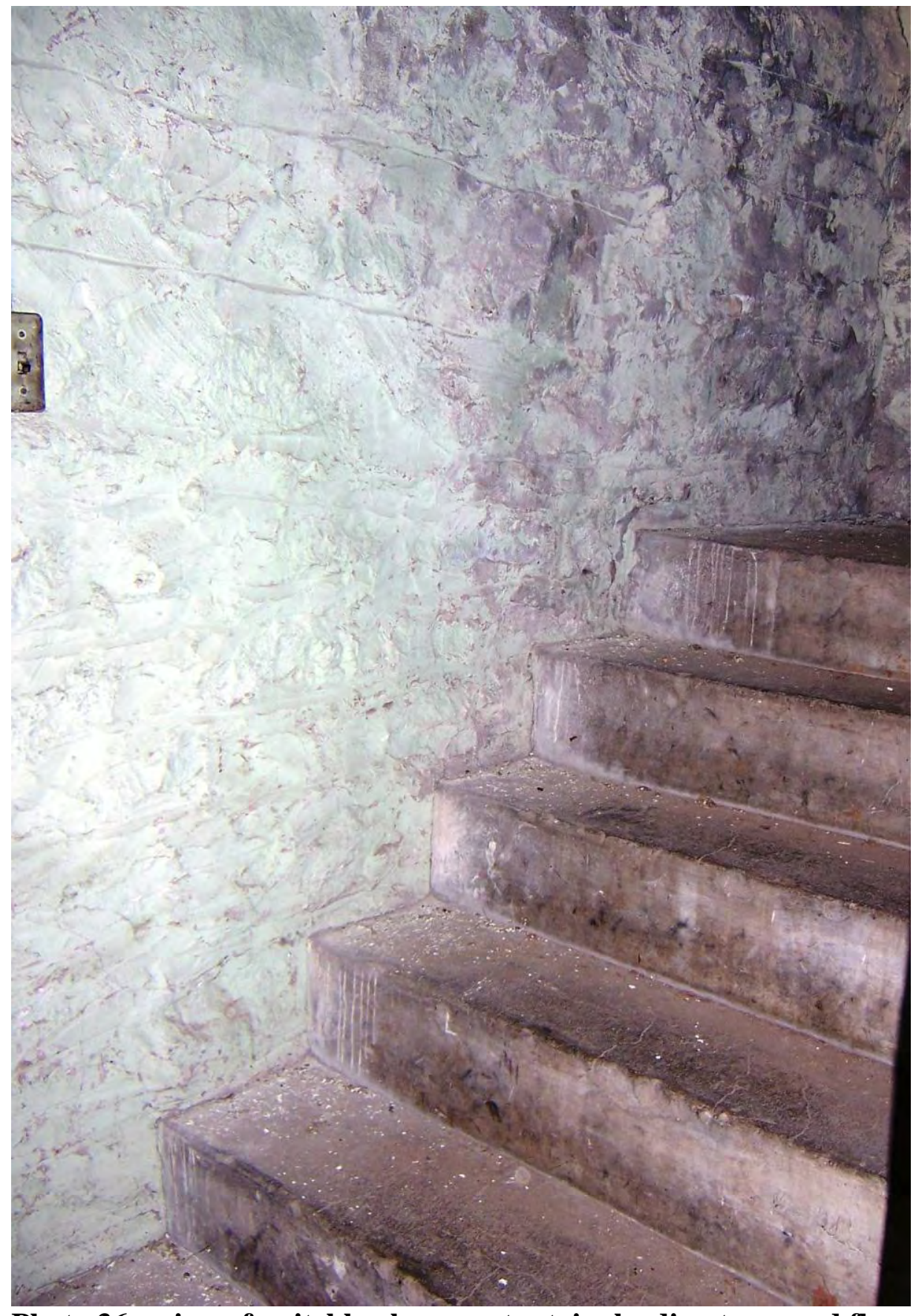

Photo 36 - view of switchback concrete stairs leading to second floor 
PYTHIAN POWERHOUSE AND LAUNDRY INTERIOR PHOTOGRAPHS (page 52)

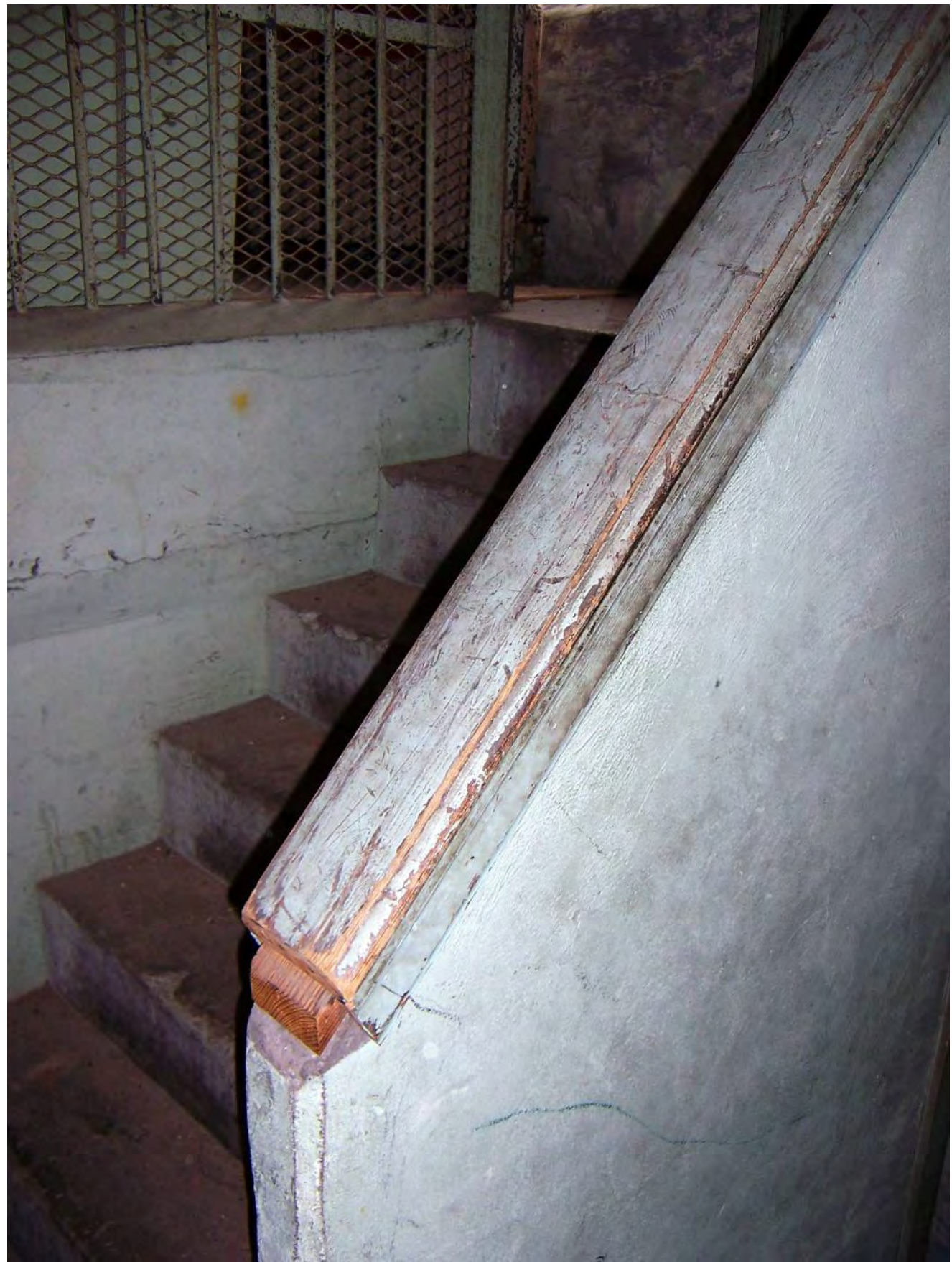

Photo 37 - detail of handrail on stairs leading to the second floor 
PYTHIAN POWERHOUSE AND LAUNDRY INTERIOR PHOTOGRAPHS (page 53)

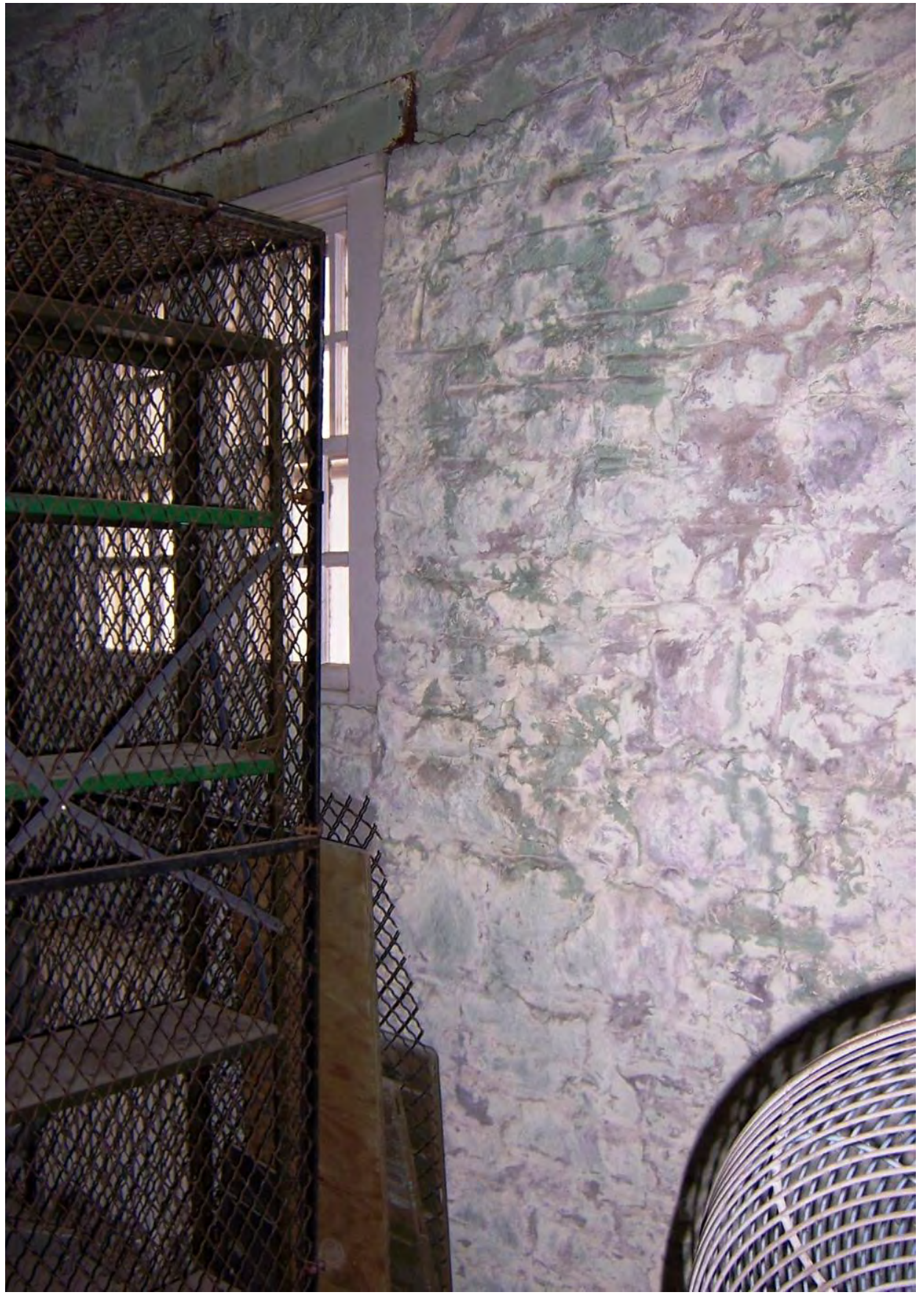

Photo 38 - interior view of cut limestone wall 
PYTHIAN POWERHOUSE AND LAUNDRY INTERIOR PHOTOGRAPHS (page 54)

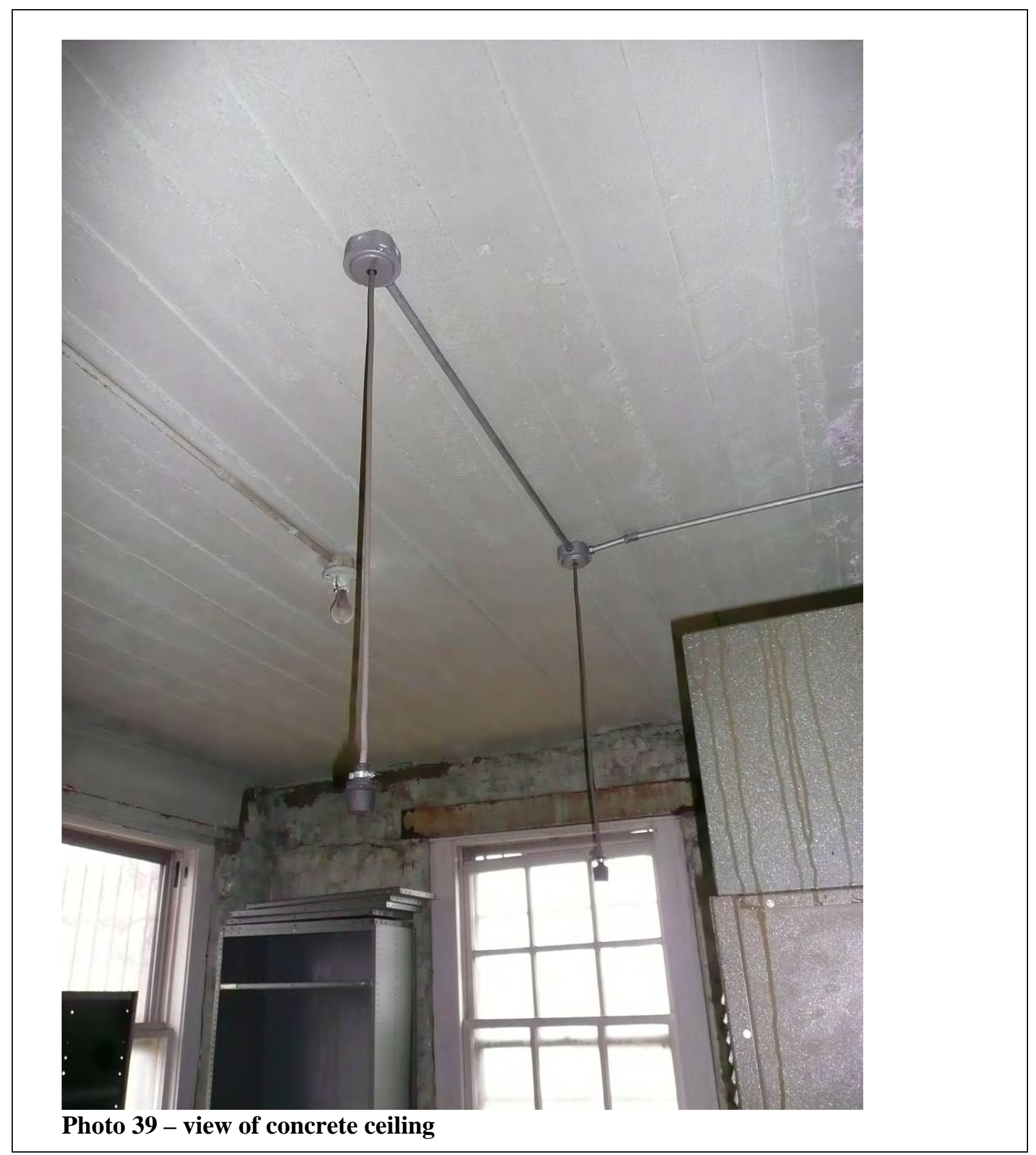


PYTHIAN POWERHOUSE AND LAUNDRY INTERIOR PHOTOGRAPHS (page 55)

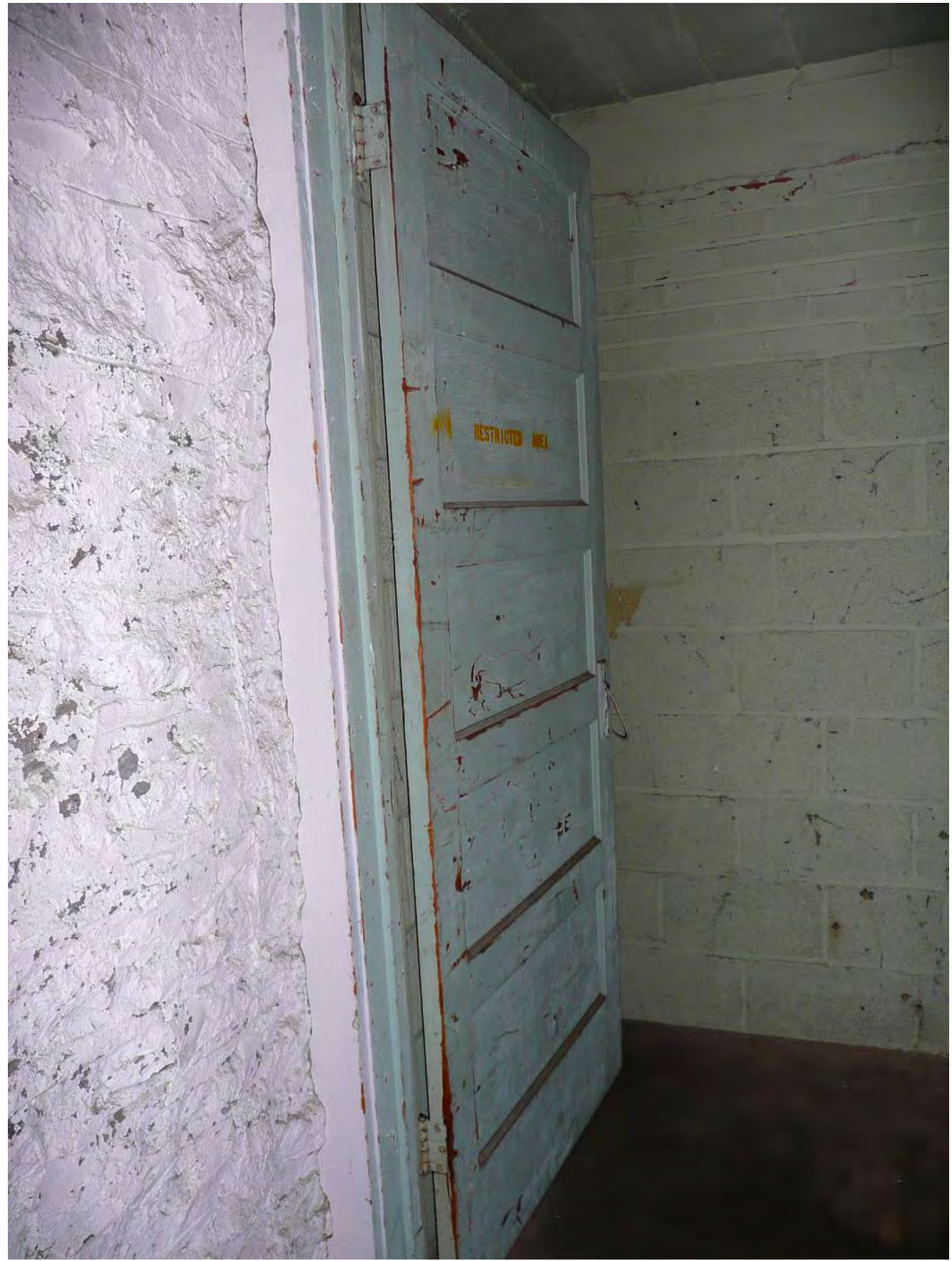

Photo 40 - view of five-panel wood interior door and door opening filled with concrete masonry units 
PYTHIAN POWERHOUSE AND LAUNDRY INTERIOR PHOTOGRAPHS (page 56)

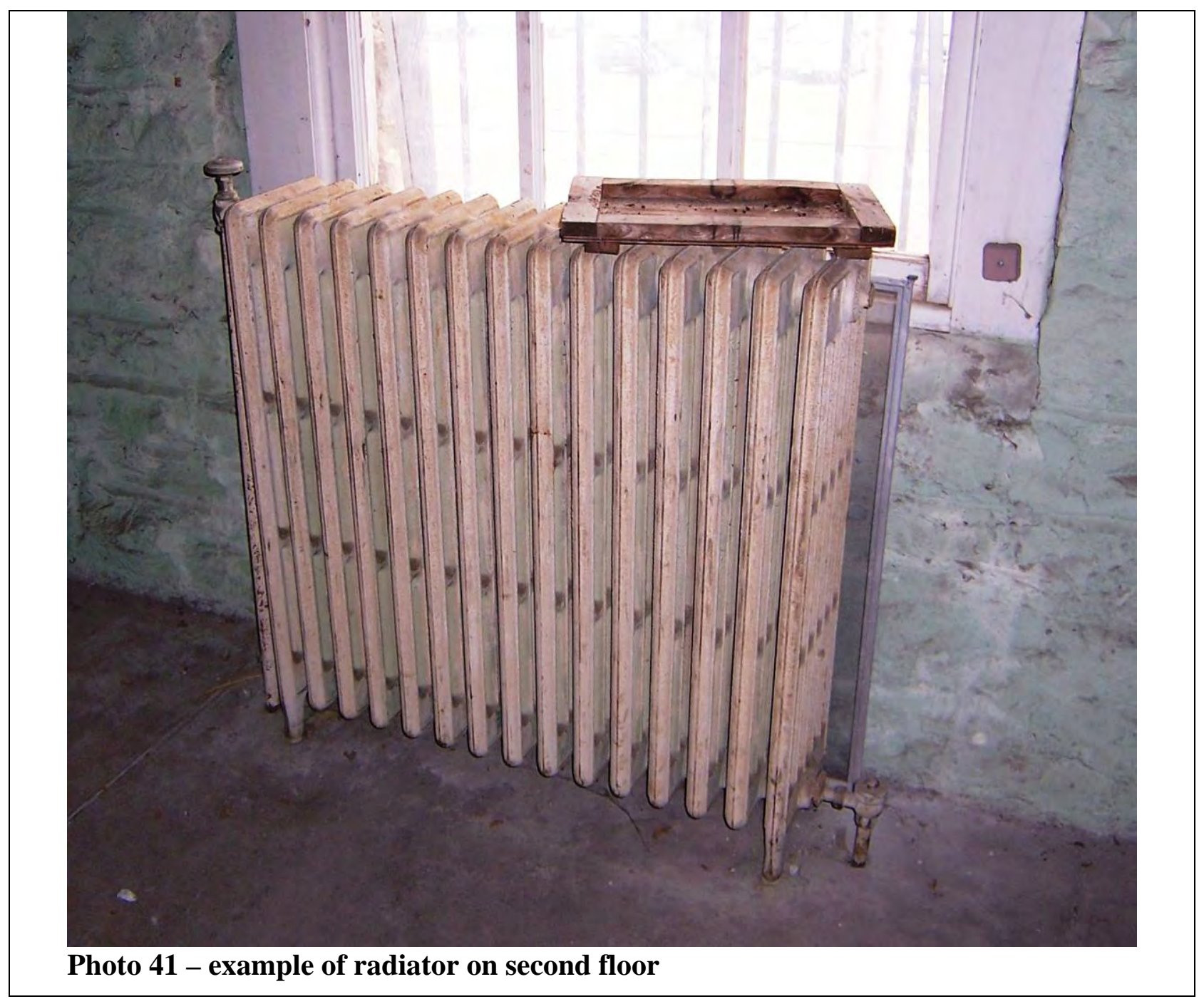




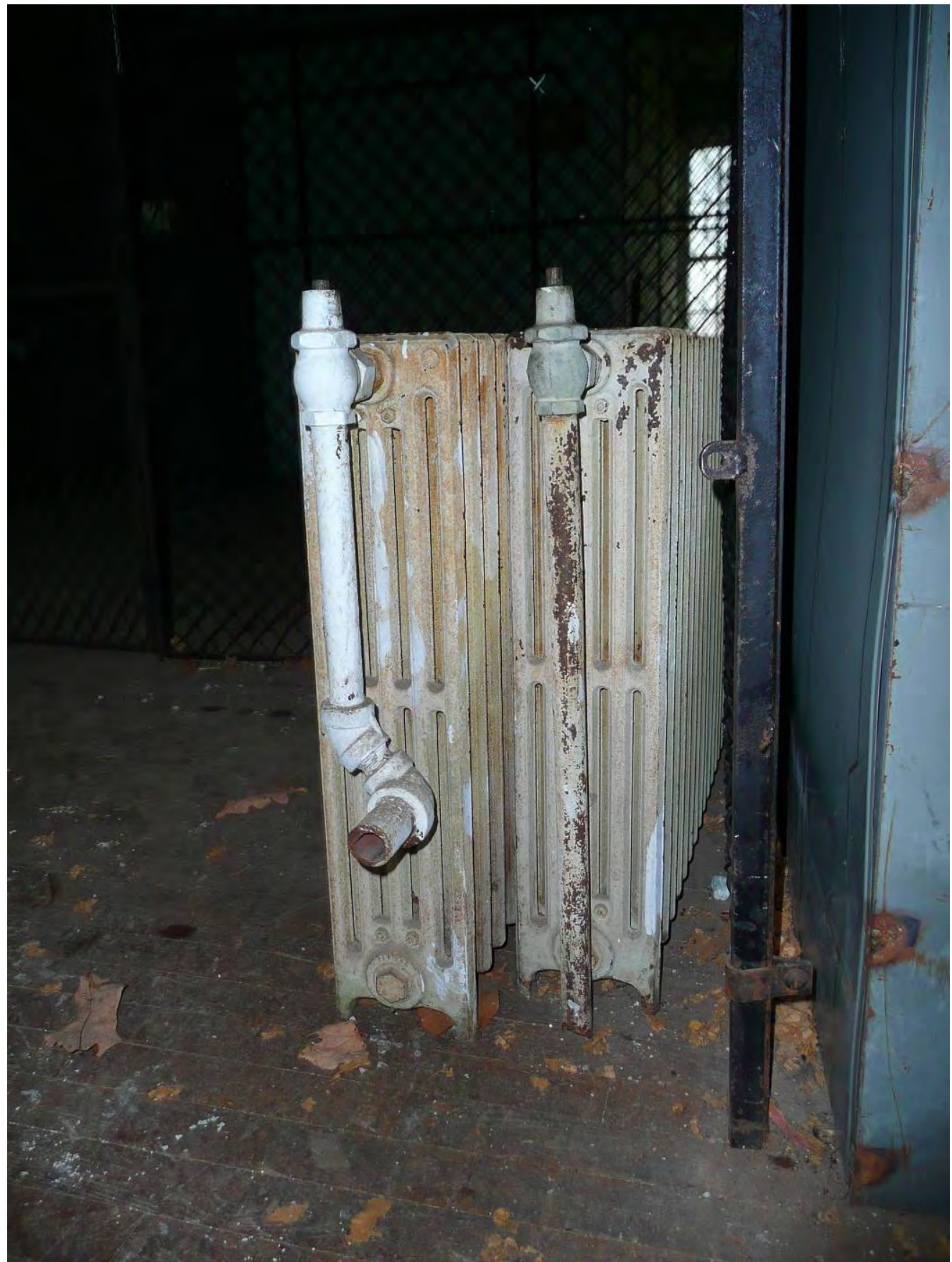




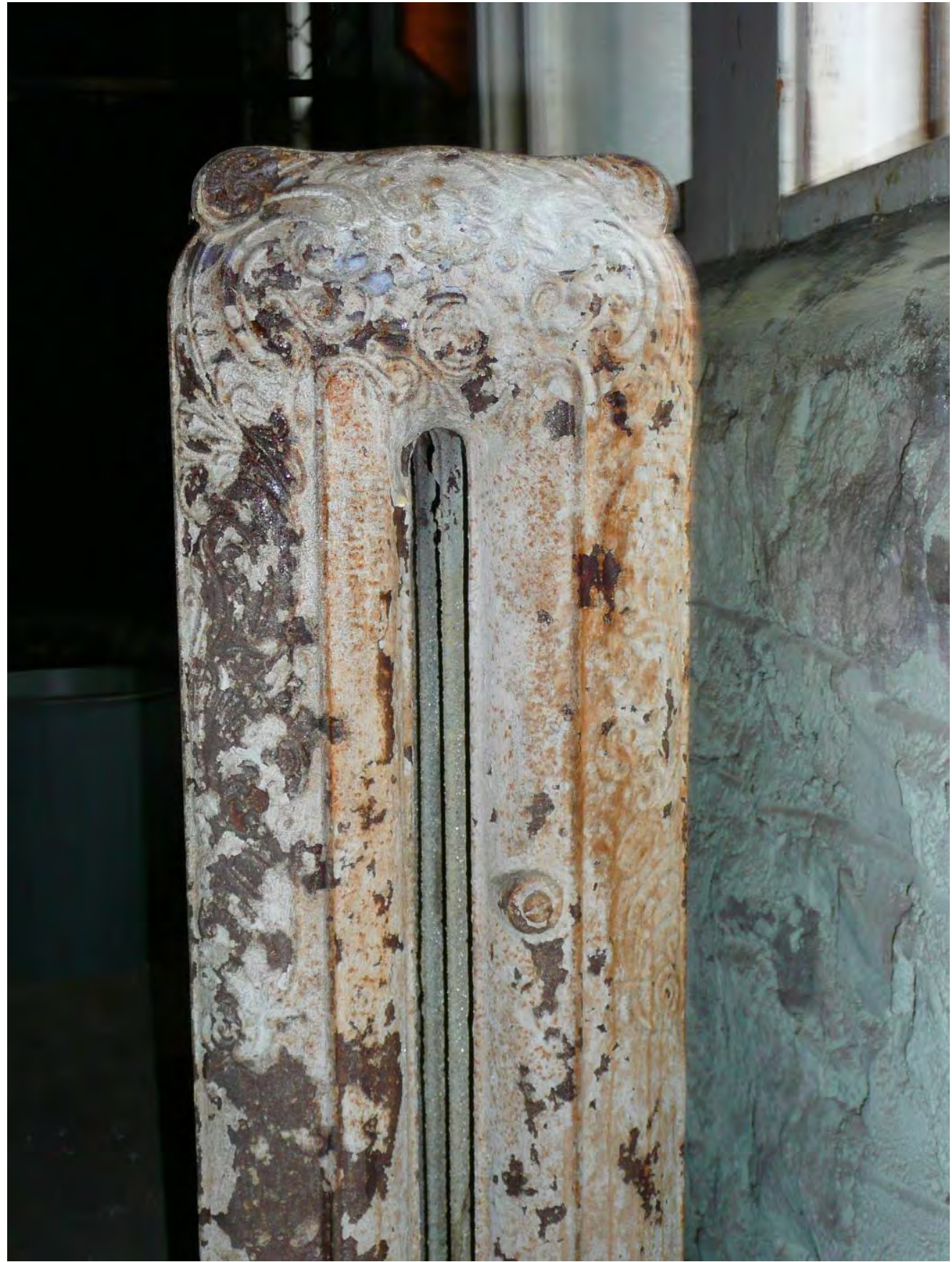




\section{ERDC-CERL SKETCH PLANS AND ELEVATIONS}

PLAN 1 SITE PLAN

PLAN 2 NORTH AND SOUTH ELEVATIONS

PLAN $3 \quad$ EAST AND WEST ELEVATIONS

PLAN 4 BASEMENT FLOOR PLAN

PLAN 5 FIRST FLOOR PLAN

PLAN 6 SECOND FLOOR PLAN

PLAN $7 \quad$ CROSS SECTION

PLAN 8 WINDOW DETAILS

PLAN 9 EXTERIOR DOOR DETAILS

PLAN 10 SOUTH ELEVATION HISTORICAL CONJECTURE

PLAN 11 SECTION HISTORICAL CONJECTURE 


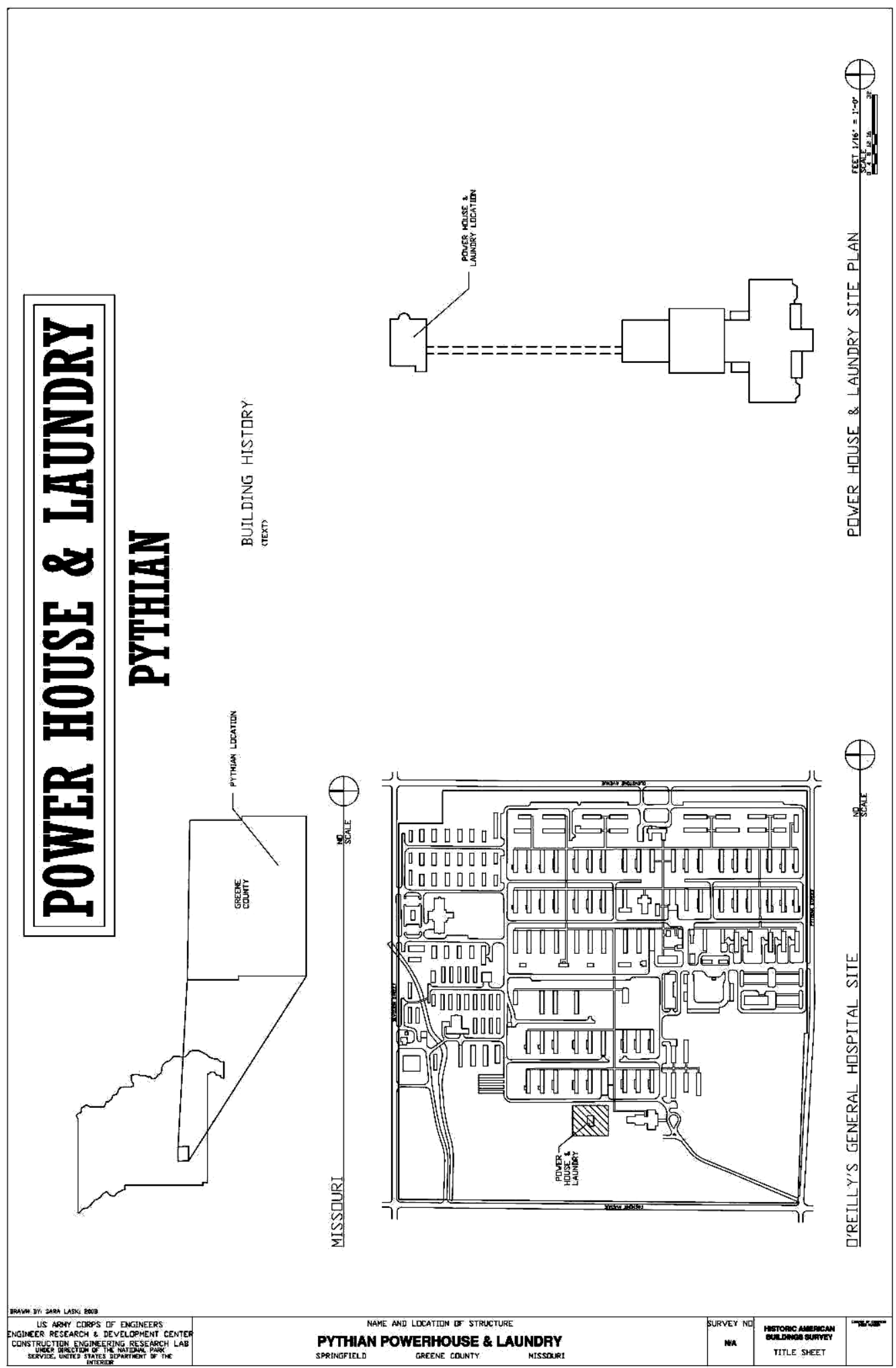

\section{PLAN 1 SITE PLAN}




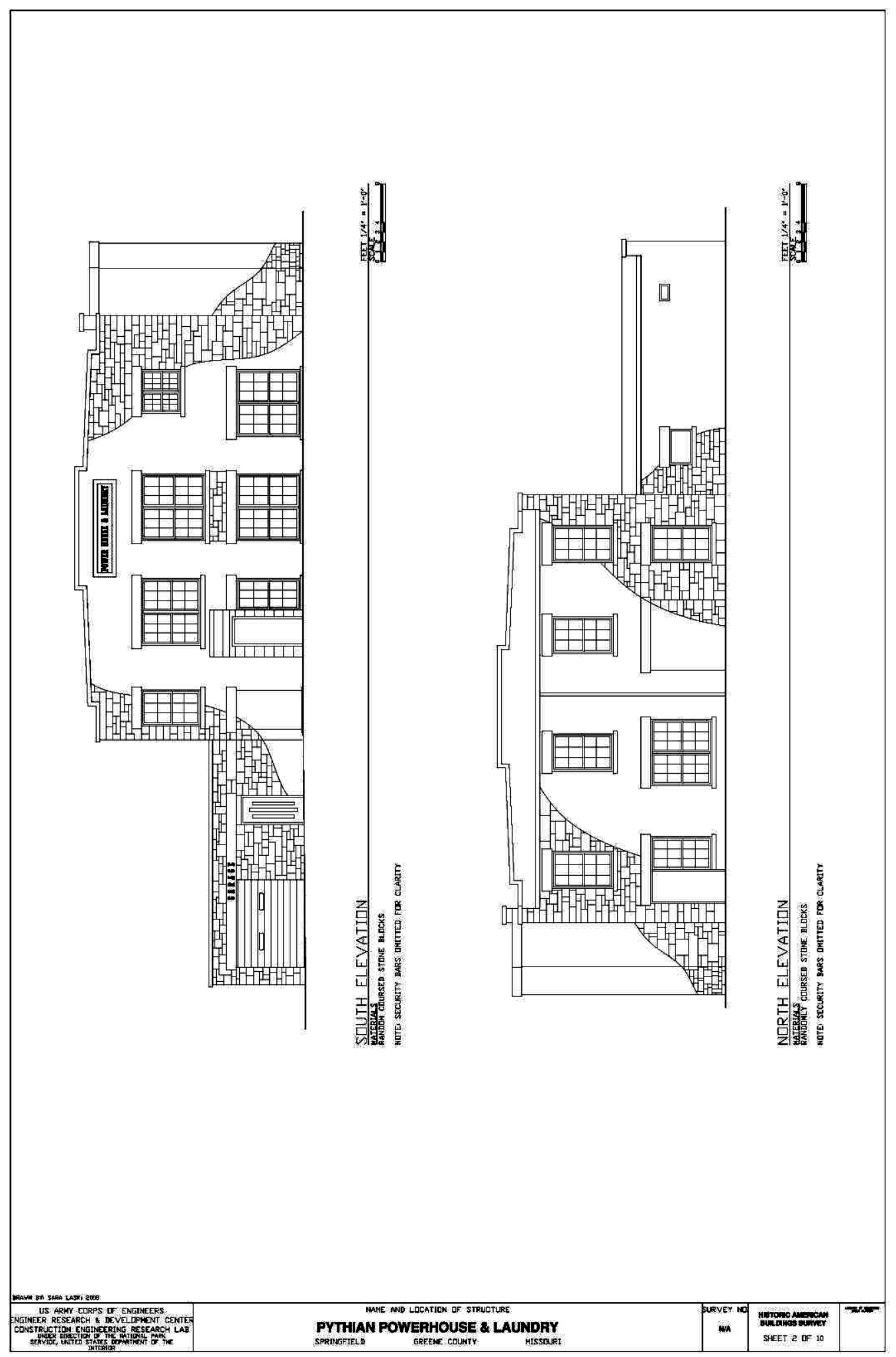

PLAN 2 NORTH AND SOUTH ELEVATIONS 


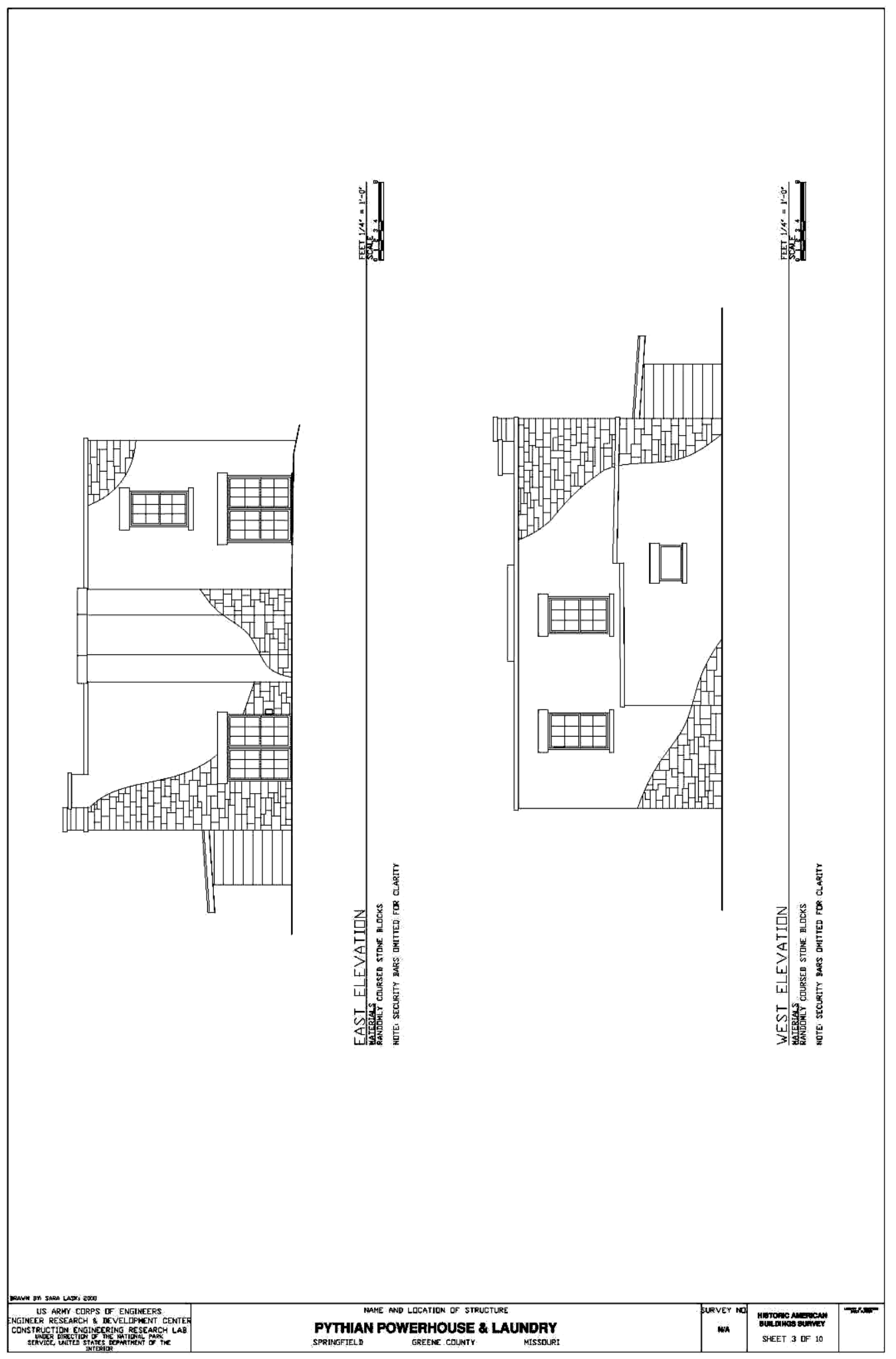

PLAN $3 \quad$ EAST AND WEST ELEVATIONS 


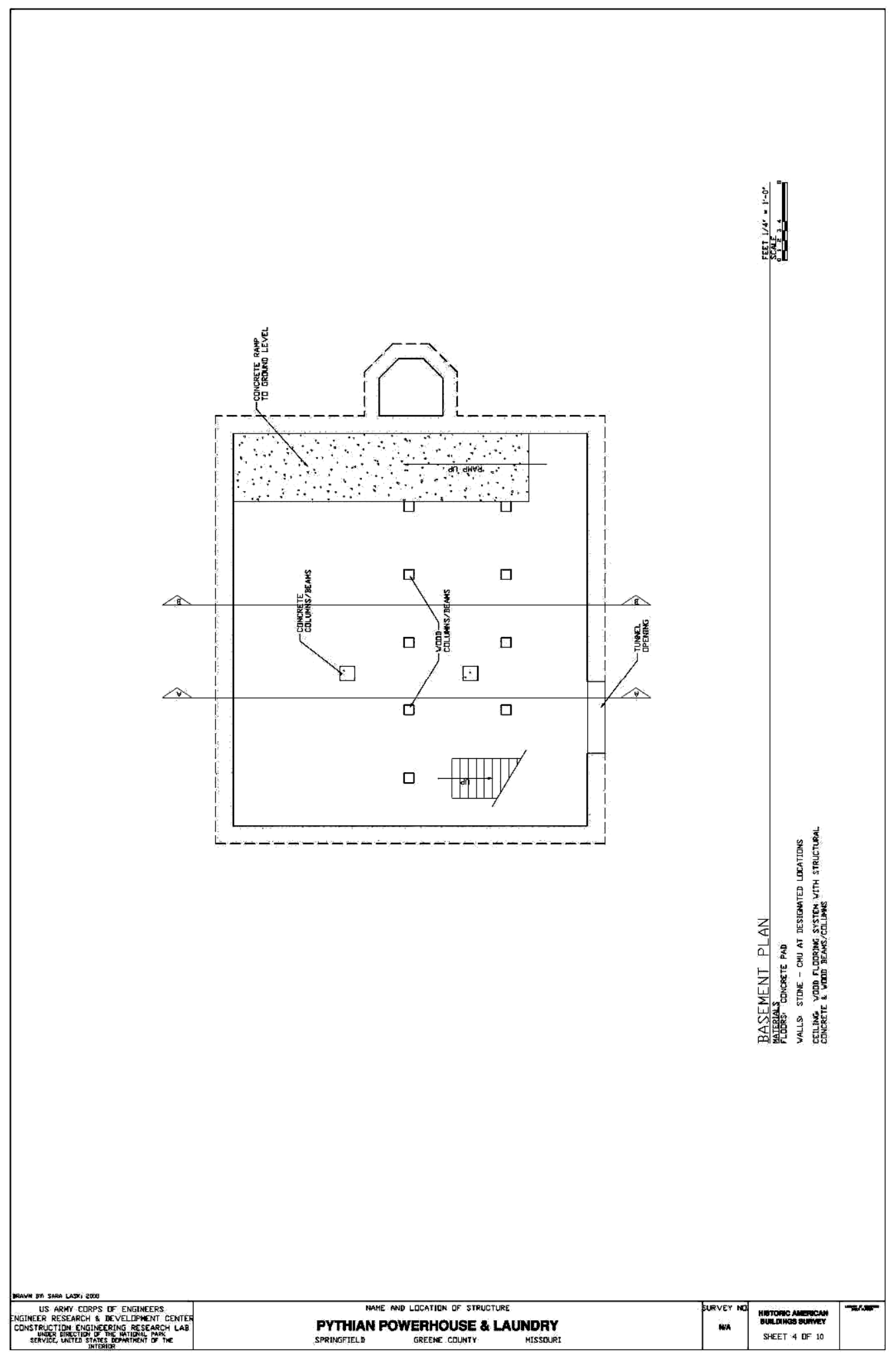

PLAN 4 BASEMENT FLOOR PLAN 
PYTHIAN POWERHOUSE AND LAUNDRY (page 64)

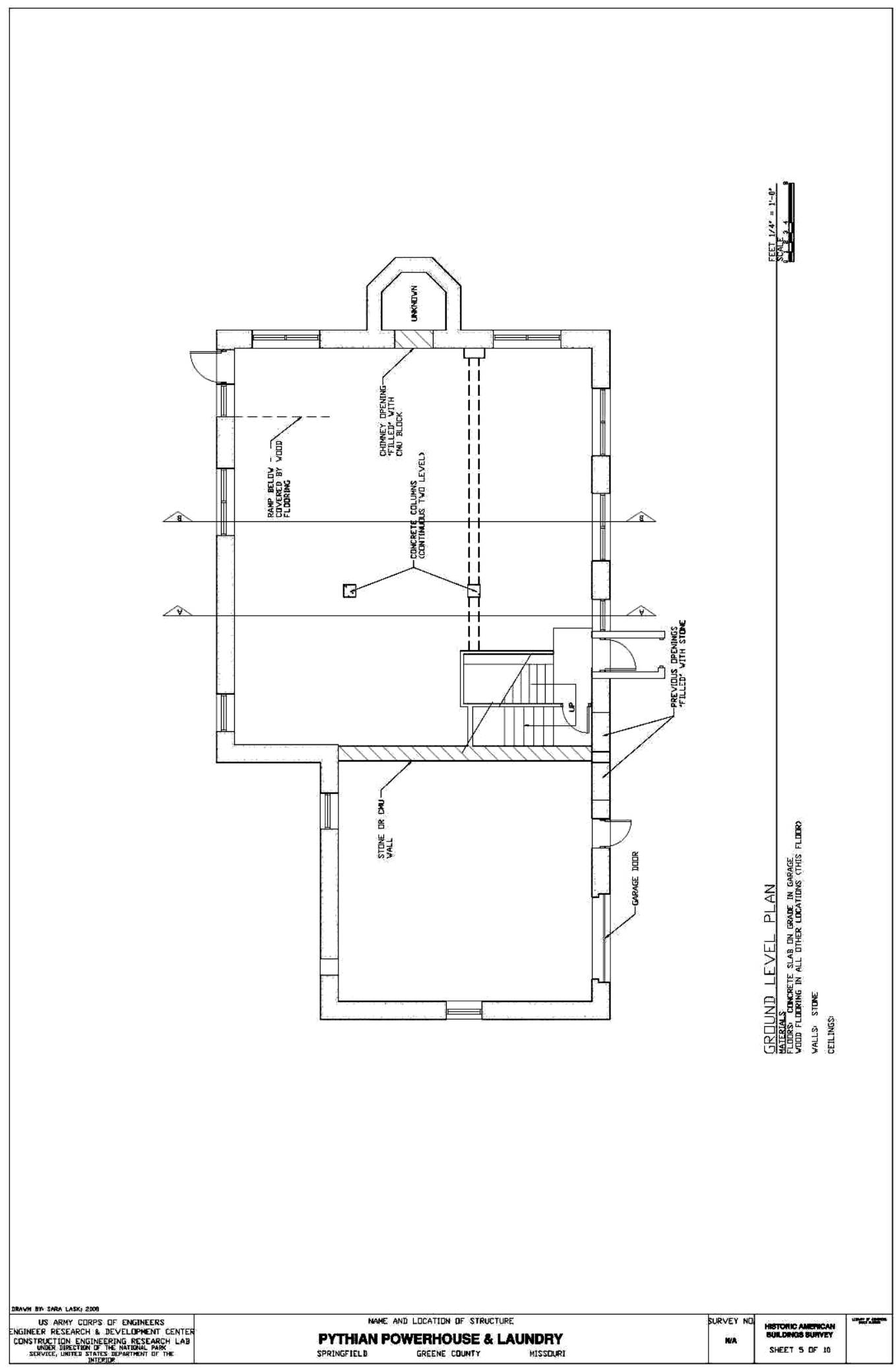

PLAN 5 FIRST FLOOR PLAN 


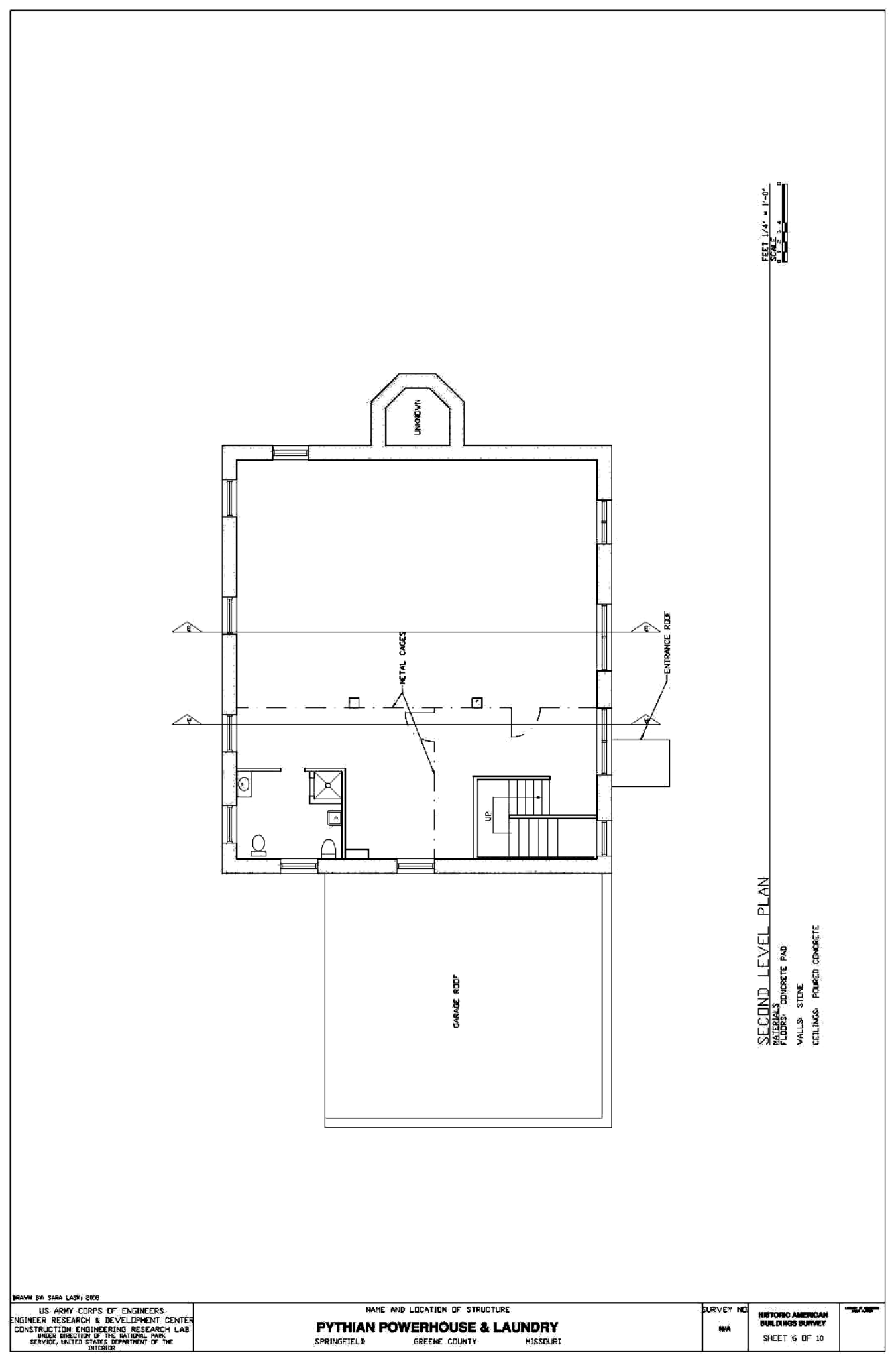

PLAN 6 SECOND FLOOR PLAN 
PYTHIAN POWERHOUSE AND LAUNDRY

(page 66)

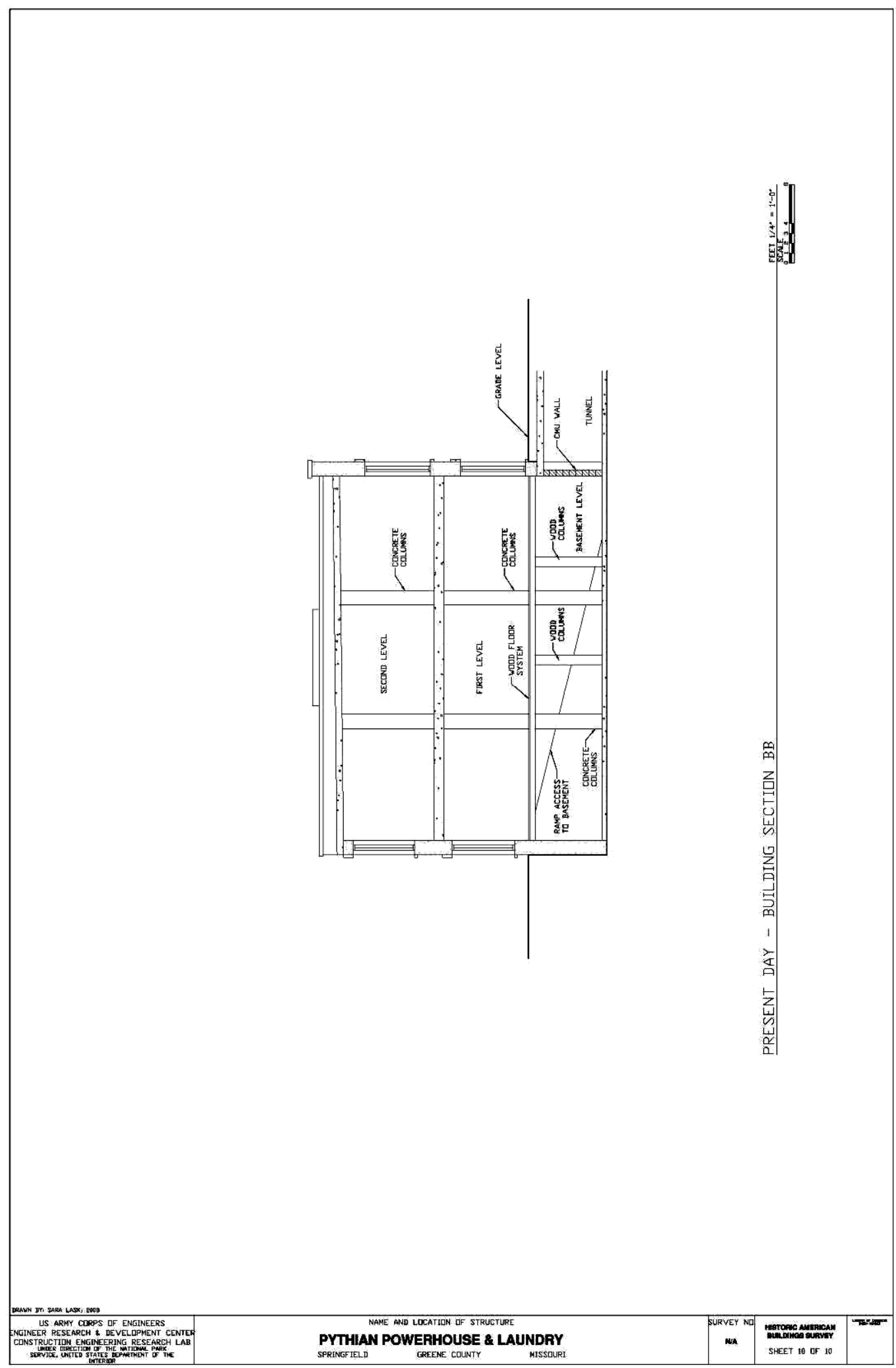

PLAN $7 \quad$ CROSS SECTION 
PYTHIAN POWERHOUSE AND LAUNDRY (page 67)

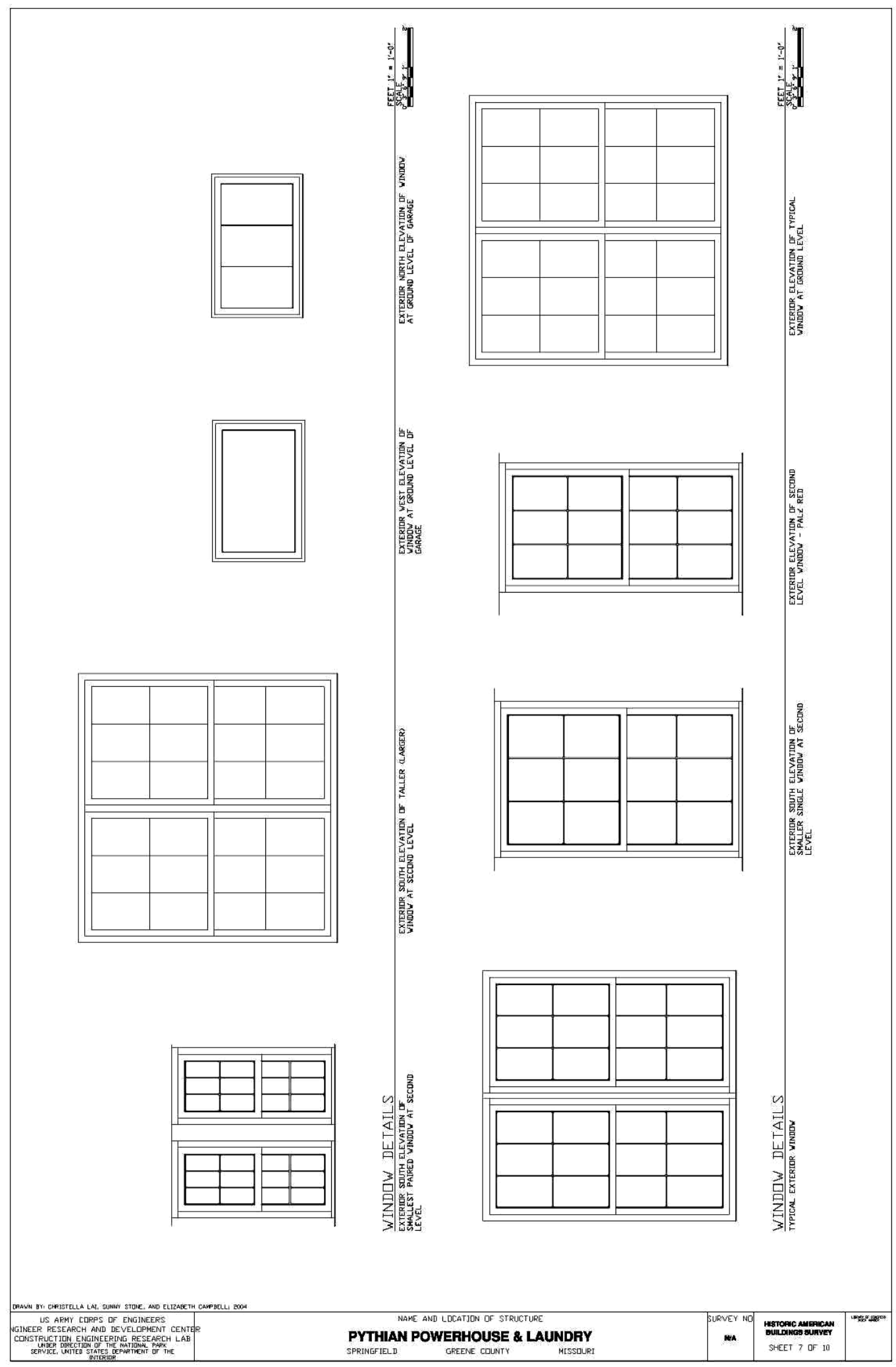

PLAN $8 \quad$ WINDOW DETAILS 


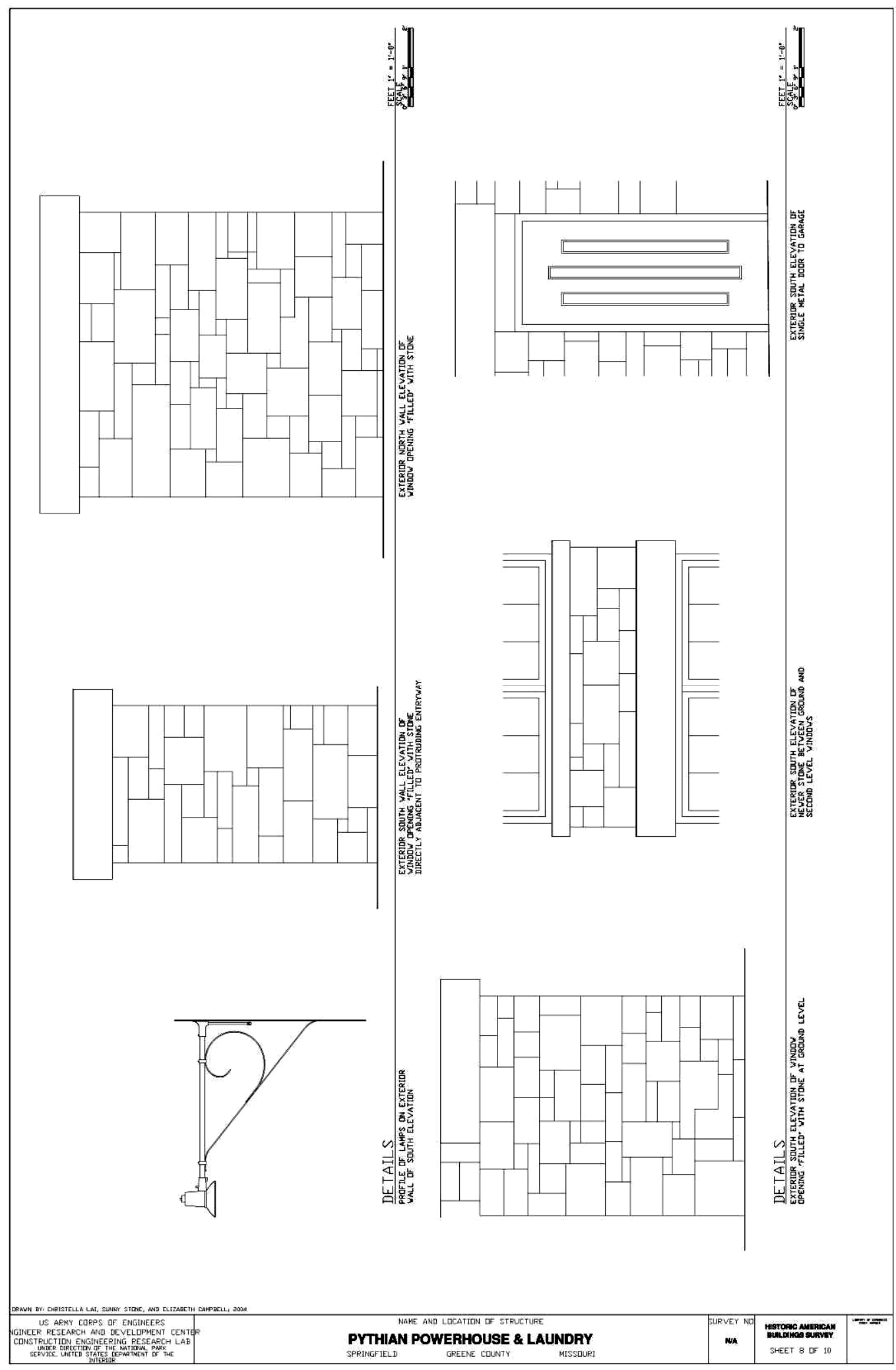


PYTHIAN POWERHOUSE AND LAUNDRY (page 69)

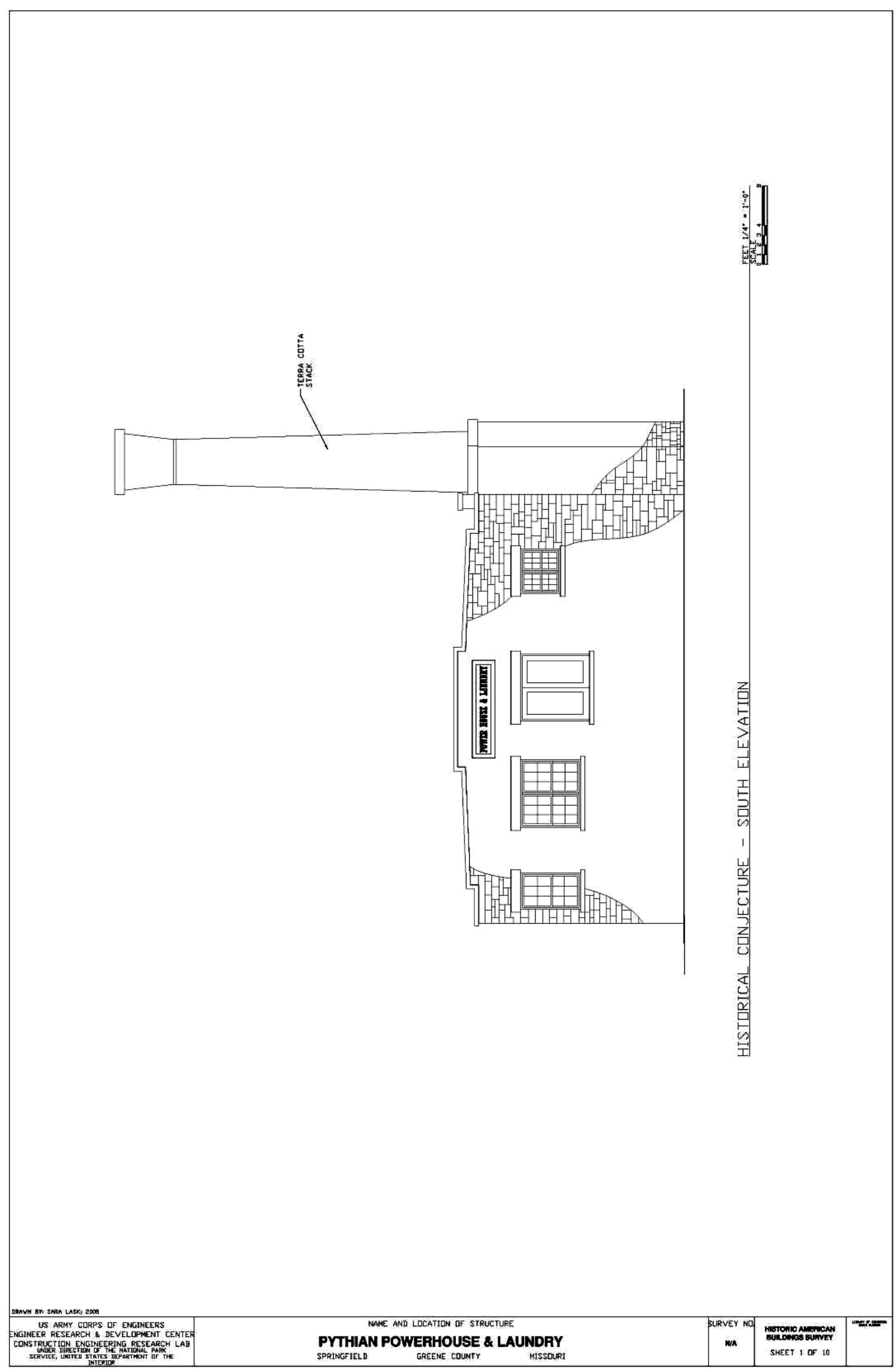

PLAN 10 SOUTH ELEVATION HISTORICAL CONJECTURE 


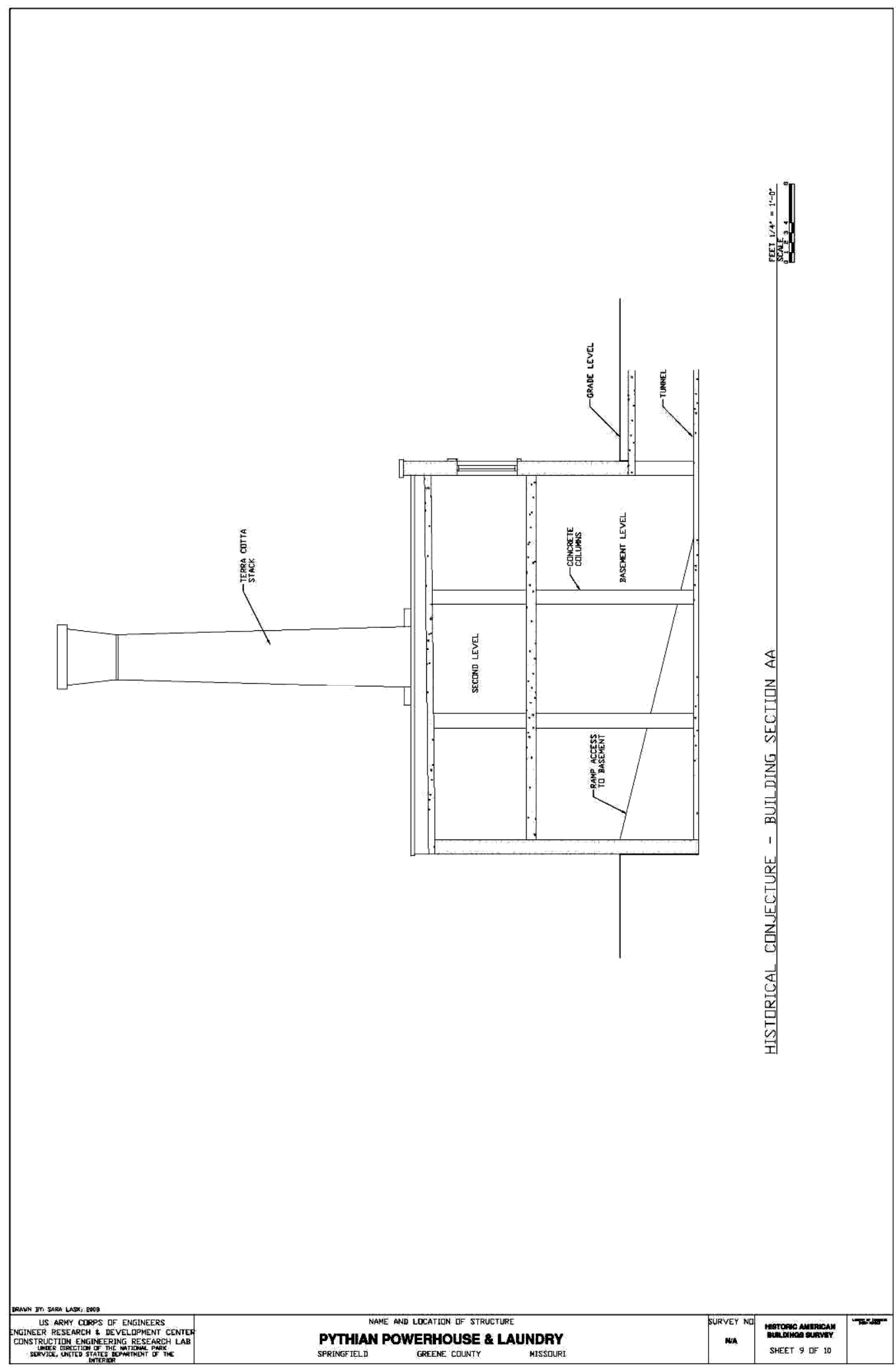

PLAN 11 SECTION HISTORICAL CONJECTURE 


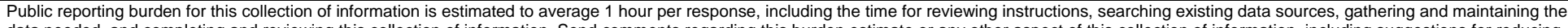

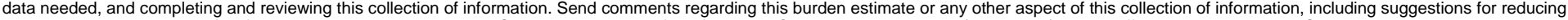

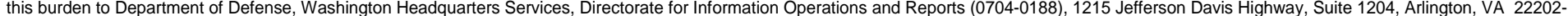

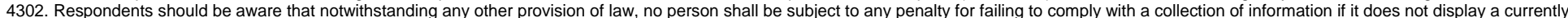
valid OMB control number. PLEASE DO NOT RETURN YOUR FORM TO THE ABOVE ADDRESS.
1. REPORT DATE (DD-MM-YYYY)
2. REPORT TYPE

\section{DATES COVERED (From - To)}

17-08-2008

Final

\section{TITLE AND SUBTITLE}

Pythian Powerhouse and Laundry:

Historic Building Survey

\section{AUTHOR(S)}

Sunny Stone, Adam Smith, and Sara Lask

\begin{tabular}{c} 
2. REPORT TYPE \\
Final \\
\hline
\end{tabular}

PE.

5a. CONTRACT NUMBER

5b. GRANT NUMBER

5c. PROGRAM ELEMENT

\section{5d. PROJECT NUMBER}

MIPR

5e. TASK NUMBER

5f. WORK UNIT NUMBER

7CDENVD001/PO

7. PERFORMING ORGANIZATION NAME(S) AND ADDRESS(ES)

U.S. Army Engineer Research and Development Center (ERDC)

Construction Engineering Research Laboratory (CERL)

PO Box 9005,

Champaign, IL 61826-9005

8. PERFORMING ORGANIZATION REPORT NUMBER

ERDC/ CERL SR-08-14

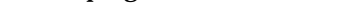

9. SPONSORING / MONITORING AGENCY NAME(S) AND ADDRESS(ES)

U.S. Army Reserve 89th Regional Readiness Command

3130 George Washington Boulevard

Wichita, KS 67210-1598

10. SPONSOR/MONITOR'S ACRONYM(S)

ATZC-DOE-C

11. SPONSOR/MONITOR'S REPORT NUMBER(S)

12. DISTRIBUTION I AVAILABILITY STATEMENT

Approved for public release; distribution is unlimited.

\section{SUPPLEMENTARY NOTES}

\section{ABSTRACT}

The Pythian Powerhouse and Laundry building is eligible for the National Register of Historic Places. This report documents the building in a similar style to the Historic American Buildings Survey standard. This report satisfies Section 110 of the National Historic Preservation Act of 1966 as amended and will help the 89th Regional Readiness Command in managing their historic building.

\section{SUBJECT TERMS}

Pyhian, National Register of Historic Places (NRHP), cultural resources management, orphanage, historic buildings, historic preservation

\begin{tabular}{|c|c|c|c|c|}
\hline \multicolumn{3}{|c|}{ 16. SECURITY CLASSIFICATION OF: } & \multirow{2}{*}{$\begin{array}{l}\text { 17. LIMITATION } \\
\text { OF ABSTRACT } \\
\text { SAR }\end{array}$} & \multirow{2}{*}{$\begin{array}{l}\text { 18. NUMBER } \\
\text { OF PAGES } \\
84\end{array}$} \\
\hline $\begin{array}{l}\text { a. REPORT } \\
\text { Unclassified }\end{array}$ & $\begin{array}{l}\text { b. ABSTRACT } \\
\text { Unclassified }\end{array}$ & $\begin{array}{l}\text { c. THIS PAGE } \\
\text { Unclassified }\end{array}$ & & \\
\hline
\end{tabular}

